Western Washington University

Western CEDAR

$6-1988$

\title{
Energetics of the Lizard Cnemidophorus Tigris and Life History Consequences of Food- Acquisition Mode
}

\author{
Roger A. Anderson \\ Western Washington University, roger.anderson@wwu.edu \\ William H. Karasov
}

Follow this and additional works at: https:// cedar.wwu.edu/biology_facpubs

Part of the Biology Commons

\section{Recommended Citation}

Anderson, Roger A. and Karasov, William H., "Energetics of the Lizard Cnemidophorus Tigris and Life History Consequences of Food-Acquisition Mode" (1988). Biology Faculty and Staff Publications. 36.

https://cedar.wwu.edu/biology_facpubs/36 


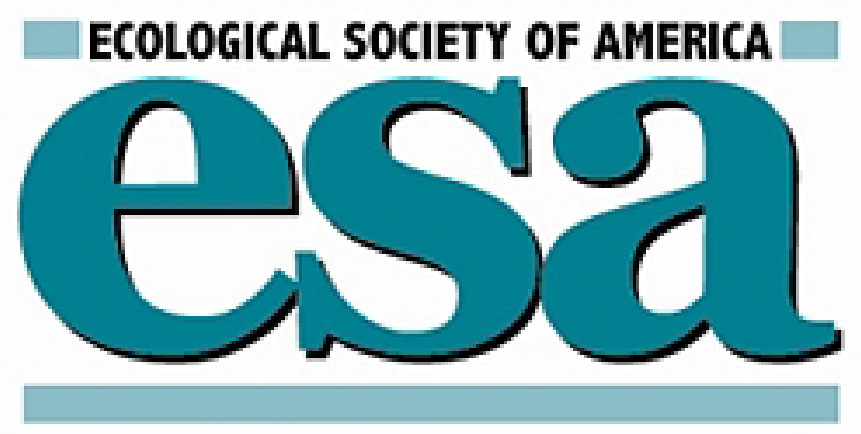

Energetics of the Lizard Cnemidophorus Tigris and Life History Consequences of FoodAcquisition Mode

Author(s): Roger A. Anderson and William H. Karasov

Source: Ecological Monographs, Vol. 58, No. 2 (Jun., 1988), pp. 79-110

Published by: Ecological Society of America

Stable URL: http://www.jstor.org/stable/1942462

Accessed: 20/01/2015 18:08

Your use of the JSTOR archive indicates your acceptance of the Terms \& Conditions of Use, available at http://www.jstor.org/page/info/about/policies/terms.jsp

JSTOR is a not-for-profit service that helps scholars, researchers, and students discover, use, and build upon a wide range of content in a trusted digital archive. We use information technology and tools to increase productivity and facilitate new forms of scholarship. For more information about JSTOR, please contact support@jstor.org. 


\title{
ENERGETICS OF THE LIZARD CNEMIDOPHORUS TIGRIS AND LIFE HISTORY CONSEQUENCES OF FOOD-ACQUISITION MODE ${ }^{1}$
}

\author{
ROGER A. ANDERSON ${ }^{2}$ \\ Department of Biology, University of California, \\ Los Angeles, California 90024 USA \\ AND \\ William H. Karasov \\ Department of Wildlife Ecology, University of Wisconsin, \\ Madison, Wisconsin 53706 USA
}

\begin{abstract}
Energy budgets for the wide-foraging "arthropodivorous" lizard Cnemidophorus tigris were constructed for the reproductive season using doubly labeled water measurements of field metabolic rate (FMR). Rates of body mass change, clutch sizes, and clutch intervals were also investigated. FMRs of both sexes (males, $298 \mathrm{~J} \cdot \mathrm{g}^{-1} \cdot \mathrm{d}^{-1} ;$ females, $247 \mathrm{~J} \cdot \mathrm{g}^{-1} \cdot \mathrm{d}^{-1}$ ) were greater in the reproductive season than during the postreproductive season. This was not due to differences in resting metabolism, but, instead, was due to higher activity costs during the reproductive season. Although males had signficantly higher FMR than females, males and females had similar feeding rates (as reflected by water influx rates). The ratio of energy intake to expenditure was higher in females than in males. Females produced eggs but did not grow. Large males did not grow, but small $1 \mathrm{st}-\mathrm{yr}$ males similar in size to females did grow. Females laid at least two consecutive clutches during a single reproductive season; clutch interval was $\approx 25 \mathrm{~d}$. Clutch size varied with time of laying (first or second clutch), female body size, and year.

We compare the reproductive energetics of $C$. tigris and other wide-foraging Cnemidophorus with the energetics of ambush iguanids. The wide forager $C$. tigris and the ambusher Uta stansburiana apparently do not differ in the proportion of the energy budget devoted to reproductive production (reproductive effort, $\mathrm{RE}_{\mathrm{p}}$ ). But total reproductive effort, $\mathrm{RE}_{\mathrm{t}}$, which includes metabolism associated with reproduction, is much lower in Cnemidophorus tigris.

Review of the literature indicates Cnemidophorus tend to lay smaller clutches and larger eggs than iguanids, but the number of eggs laid per unit time generally equals that of most iguanids. Cnemidophorus also deposit energy into their eggs at rates almost $60 \%$ higher than ambush iguanids. We consider higher rates of production in wide foragers to be permitted by their higher rates of net energy intake while foraging, compared with most ambushers. These higher rates of production in Cnemidophorus apparently allow them either to reach a larger size than iguanids of similar age at first reproduction or to be younger than iguanids of the same size at first reproduction. Life history characters may be influenced by differences in rates of production associated with different food-acquisition modes.
\end{abstract}

Key words: Cnemidophorus; doubly labeled water; energetics; food-acquisition mode; life history; lizard; production rates; reproductive effort; wide foraging.

\section{INTRODUCTION}

The daily rates of energy acquisition, assimilation, and metabolism generally limit the maximum daily rate of production (growth, reproduction, storage) of individuals or a population of animals. Widely foraging predatory lizards have been found to have high rates of energy intake per unit foraging time, compared with syntopic lizards that employ ambush (sit-and-wait)

\footnotetext{
${ }^{1}$ Manuscript received 21 August 1986; revised 3 August 1987; accepted 23 September 1987.

${ }^{2}$ Present address: Savannah River Ecology Laboratory, Drawer E, Aiken, South Carolina 29801 USA.
}

predation (Anderson and Karasov 1981, Andrews 1984, Nagy et al. 1984). Wide foragers (better named intensive foragers, sensu Regal 1978) spend much of their activity period moving in search of sedentary and fossorial prey, which they detect via olfaction as well as vision (Anderson 1986). In contrast, ambushers spend most of their activity period sedentary and visually search for mobile prey (Anderson and Karasov 1981, Nagy et al. 1984). Wide foragers have higher rates of energy expenditure than ambushers; but because all wide foragers studied have a much higher rate of energy intake per unit foraging time, their net rates of energy intake (intake minus expenditure) are higher than those 
of ambush predators (Anderson and Karasov 1981, Andrews 1984, Nagy et al. 1984). Whether wide foragers consequently have higher daily rates of production is unknown.

Wide-foraging lizards generally have smaller clutch mass relative to body mass than do ambush lizards of similar size (Vitt and Congdon 1978). But, because individual female lizards are capable of more than one clutch within a reproductive season (Vitt 1977), it is possible that under certain environmental conditions wide foragers may have rates of egg production (both mass and number) equal to those of ambush predators. A general comparison of wide foragers and ambushers in rate of egg production has not been conducted. Most studies of reproduction in lizards have focused on body size : clutch size relationships, rather than the time required per clutch, although there are notable exceptions in studies of ambush iguanids (Tinkle 1967, Turner et al. 1976, Dunham 1981, Van Loben Sels and Vitt 1984; S. Jones, personal communication). Analysis of these and other details of reproduction in wide foragers, ambushers, and lizards with other food-acquisition modes may result in new discoveries about the differing effects these modes have on reproductive potential.

Another theoretical impetus for investigating reproductive production is the longstanding interest in understanding and predicting the optimal allocation of energy resources to growth, storage, and reproduction (Fisher 1930, Williams 1966, Hirshfield and Tinkle 1975). Arrested or reduced growth rates of animals in the midst of reproduction are supportive evidence that trade-offs in energy allocation occur (Congdon et al. $1982 a$ ). The absolute and relative rates of maintenance metabolism and the rates of allocation to each of three types of production (growth, storage and reproduction) certainly must vary under differing environmental conditions (in both an evolutionary and proximal sense) if an individual is to have high reproductive success. The principal parameter of interest with which to investigate the energy commitment to reproductive success has been reproductive effort (RE). "Reproductive effort is defined as the proportion of total energy procured over a specified and biologically meaningful time interval that an organism devotes to reproduction" (Hirshfield and Tinkle 1975).

As explicated by Stearns (1977) and Congdon et al. (1982a) there are two broad hypotheses about which selection pressures govern the level of RE and other life history traits. These alternative selection scenarios are: (1) patterns of resource availability ( $r$ - and $K$-selection) and (2) patterns of age class survivorship (bet hedging). Data on RE and several other life history parameters, such as age at maturity, offspring size, interval between reproductive bouts, and reproductive bouts per lifetime, are necessary for proper testing of either of these two hypotheses.

Among studies of reptiles there are few data sets available with which to assess REs and compare them with extant selection pressures. We are perennially faced with the following questions: What are the patterns of energy allocation common to particular age and sex classes within a species, and how does RE compare among species that reproduce via semelparity or at various levels of iteroparity, and among species that differ in life spans, body sizes, and food-acquisition modes? What patterns appear among environmentally different seasons, years, and habitats?

Recent treatments of reproduction in lizards have investigated components of the energy cost of reproduction other than simply the energy in the clutch. Some of these components include energy allocated to (1) courtship, (2) competition for mates, (3) nesting, (4) the food-acquisition effort necessary to supply energy for these activities and for the clutch of eggs (Vitt and Price 1982, Congdon et al. 1982a), and (5) the respiratory cost of production associated with the conversion of food into new tissue (Ricklefs 1974). A simple, testable hypothesis would be that the energetic sum total of these components of the costs of reproduction would be manifested in higher daily field metabolic rates (FMR) of lizards during the reproductive season than during the nonreproductive season. In some cases an increased FMR during the reproductive season has been demonstrated (Nagy 1983, Merker and Nagy 1984), but there has been at least one exception (Bennett and Nagy 1977). The precise causes of these increases in FMR during reproductive periods have not been identified in these studies. Furthermore, these studies of FMR during reproductive and nonreproductive "seasons" have been concerned with only iguanid lizards, which employ the ambush mode of predation. And, given the host of differences already discovered and hypothesized between ambushers and wide foragers (Pianka 1966, Gerritsen and Strickler 1977, Regal 1978, Anderson and Karasov 1981, Huey and Pianka 1981, Vitt and Price 1982), studies of FMR of reproductive wide foragers might be illuminating.

We investigated the reproductive energy budgets of a widely foraging teiid lizard, Cnemidophorus tigris. First, we wanted to determine whether FMR and feeding rate were higher during the reproductive season than our previous measurements of FMR and feeding rate during the postreproductive season (Anderson and Karasov 1981). Measurements of standard metabolic rate (SMR) and observations on reproduction and behavior in the field allowed us to partition an increase in FMR into its physiological and behavioral causes.

In a prior study we found $C$. tigris to have higher rates of food acquisition and field energy expenditure than the iguanid Callisaurus draconoides during the concurrrent postreproductive periods of both species (Anderson and Karasov 1981). We have investigated here the intriguing idea that wide foragers, which eat mostly arthropods and other invertebrates, may have 
higher rates of production (reproduction, growth, and storage) than most ambushers, which also predominantly eat arthropods.

We also evaluate Cnemidophorus reproductive energetics for several alternative measures: (1) rates of energy allocation to reproduction; (2) the proportion of the total energy budget devoted to reproduction (RE); (3) the number of eggs laid per unit time; and (4) the mass of the clutch relative to adult body mass (relative clutch mass, RCM; Vitt and Congdon 1978, Congdon et al. 1982a, Nagy 1983). We discuss the relative usefulness of these measures in understanding the biology and life history of Cnemidophorus and the ecology and evolution of lizard life histories in general.

\section{Methods}

A portion of a population of Cnemidophorus tigris in the Chuckwalla Valley of the Colorado Desert near Desert Center, Riverside County, California, was studied from 1979 to 1983 . On the 6-ha study site $(200 \times$ $300 \mathrm{~m}$; described in Anderson 1986) individuals were toe-clipped (no more than one toe per foot, three total) for permanent identification. Short, thin paint stripes, to aid in subsequent identification of the individuals from a distance, were applied longitudinally to the dorsum of each individual. All individuals were released at location of capture. Subsequent recapture of marked lizards provided data on changes in body length and mass (weighed to the nearest $0.01 \mathrm{~g}$ on triple beam balance), and, for females, reproductive condition (detected by palpation and by visual inspection). Additional lizards from areas near the study site were occasionally collected for determination of reproductive condition (see Anderson 1986), stomach contents, and for laboratory measurements of resting metabolic rates.

\section{Rates of field metabolism and water influx}

During the 1980 reproductive season (April and May) of $C$. tigris, field metabolic rates (FMR) and water influx rates were measured using the doubly labeled water method (Lifson and McClintock 1966). Congdon et al. (1978) and Nagy (1983) validated this method for other lizards. Injection and sampling procedures are described elsewhere (Anderson and Karasov 1981). We captured and injected lizards during 12-14 April, and recaptured and sampled them $\approx 16 \mathrm{~d}$ later (range $14-$ $21 \mathrm{~d})$.

For each lizard, initial body water content was determined from the dilution of oxygen-18 $\left({ }^{18} \mathrm{O}\right)$, and final body water content was estimated based on the mean percent of body mass that was water in the initial group. There was no statistically significant difference between the sexes in body water content ( $t$ test, $P>$ .05). The mean \pm SEM for C. tigris in April 1980 (74.5 \pm $0.8 \%, n=18$ ) was similar to that for $C$. tigris at this site in June $1979(73.8 \pm 0.5 \%, n=16)$ (Anderson and Karasov 1981). Eq. 2 of Nagy (1980) was used to calculate $\mathrm{CO}_{2}$ production and Eq. 4 of Nagy and Costa (1980) was used to calculate water influx.

We were concerned that insemination of female lizards by labeled (i.e., "hot") male lizards, or some other form of contact, would violate the assumption that labeled water does not enter the animal during the measurement period. To evaluate the magnitude of this possible error we checked for tritium $\left({ }^{3} \mathrm{H}\right)$ activity in 11 female $C$. tigris on the study plot that we had not injected with labeled water. Seven of these females (64\%) had ${ }^{3} \mathrm{H}$ activities above background (1.5 Bq per $5 \mu \mathrm{L}$ body water); the average ${ }^{3} \mathrm{H}$ activity, corrected for background, was $4.8 \pm 1.1 \mathrm{~Bq}$. Labeled female lizards recaptured and sampled on the same days as these seven females had activities more than two orders of magnitude greater than this $(706 \pm 68.4 \mathrm{~Bq}$ per 5 $\mu \mathrm{L}, n=6)$. Thus, transfer of labeled water between labeled lizards would change body water ${ }^{3} \mathrm{H}$ activities by $<1 \%$. This is within the level of precision of our counting procedures and would have a very small effect on calculated $\mathrm{CO}_{2}$ production or water influx. Errors due to transfer of $\mathrm{HH}^{18} \mathrm{O}$ between lizards should be similarly small.

As in other studies (Anderson and Karasov 1981, Karasov and Anderson 1984), $\mathrm{CO}_{2}$ production rates were converted from cubic centimetres of $\mathrm{CO}_{2}$ per day to joules per day using the relationship $25.7 \mathrm{~J} / \mathrm{cm}^{3} \mathrm{CO}_{2}$ (determined for a fed, insectivorous lizard: Nagy 1983). Metabolic water production of each lizard was calculated using the conversion factor $0.026 \mathrm{~mm}^{3} / \mathrm{J}$ metabolized (Schmidt-Nielsen 1975).

\section{Environmental conditions and lizard activity patterns}

Observations of daily behavior patterns, body temperatures, and air and burrow temperatures were made in order to partition FMR measurements into costs of maintenance and activity and to interpret possible differences in FMR between sexes within a sample or between April and June samples.

Soil temperatures at $10,20,40$, and $60 \mathrm{~cm}$ depths were measured and recorded with thermistor probes connected to a multichannel Rustrak recorder. The probes were buried at the south perimeter of an Olneya tree such that the location received sunlight filtered through branches for part of the morning. This location was representative of locations of $C$. tigris burrows ( $R$. A. Anderson, personal observation). Soil surface temperatures in sun $\left(T_{\mathrm{ss}}\right)$ and those in shade were measured hourly with a Schultheis rapid-registering cloacal thermometer. Soil surface temperatures $>50^{\circ} \mathrm{C}$ were measured with a standard $-10^{\circ}-100^{\circ}$ glass bulb mercury thermometer. Hourly measurements of air temperatures were also made at $1 \mathrm{~cm}$ and $1 \mathrm{~m}$ above both shaded and unshaded soil surfaces. 
We estimated the length of the primary (also the first) activity period of the day for the "average" individual C. tigris on the site by determining, for the population, the average times of emergence from burrows and of retreat to burrows. The mean emergence time of $C$. tigris was determined by searching the site each day for the first lizards, prior to and including the time that we anticipated they would emerge; that is, when $T_{\mathrm{ss}}$ reached $\approx 30^{\circ}$ (Anderson and Karasov 1981). The average time that $C$. tigris ceased morning activity was obtained during tape recorded observations of individuals.

The relative level of activity of the population, i.e., the apparent abundance of individuals during each hour of the day, was estimated by the searching time required to find lizards during each hour. We compared the estimate of the low level of activity in the population in the afternoon (Anderson and Karasov 1981) with activity in the morning. Because a good estimate of the length of morning activity had already been obtained via direct observation, this procedure allowed us to modify (i.e., increase) our estimate of the mean total time devoted to activity by individuals each day. We also compared the peak level of activity for the population in the reproductive season with the peak for the nonreproductive season.

We made no attempt, due to logistical problems, to verify that each labeled individual was active every day. Reasons for assuming individuals were active every day during the reproductive season will be discussed later.

\section{Behavior}

Detailed behavioral observations were made by watching individuals for typically $30 \mathrm{~min}$ (range is 15 min to $2 \mathrm{~h}$ ). We have described elsewhere (Anderson and Karasov 1981) how C. tigris at this site are observed with relative ease. Because $C$. tigris moved almost continuously and required constant visual attention by the observer, all observations were described verbally and recorded on a portable audio tape recorder. A stopwatch was used when transcribing the tapes so that duration of each behavior was accurately measured. Times spent in locomotion, sitting, digging, climbing, basking, prey capture bouts, and interactions with other lizards, distances travelled, and duration at each location were quantified (Anderson 1986).

\section{Diet}

Males and females were captured for analyses of diet and reproductive condition generally between mid- and late morning to ensure that (1) there would be more than a few prey in each stomach and (2) there had been minimal digestive breakdown of the prey. Stomach contents were removed by dissection and preserved in $70 \%$ ethanol. In the laboratory, prey items were usually identified to family or genus, and sometimes to species.

We also measured prey lengths in order to estimate prey dry masses using published relationships between length and dry mass for each taxonomic order (Rogers et al. 1977, Sage 1982). Measurements of items in the diet were made from the most anterior part of the head to the tip of the abdomen, with a Vernier calipers, to the nearest $0.5 \mathrm{~mm}$, under a dissecting scope. We made body length measurements on $>90 \%$ of the 310 nontermite prey. We measured a sample of the 309 termites found in the stomachs, and took $3.5 \mathrm{~mm}$ as their average length. Subsequently, we calculated the proportion by dry mass in the diet for each prey type.

To calculate feeding rate from water influx data, we needed to know the water content of the diet. To estimate this, we used published values of water content of each prey type (refer to Table 3 ), and weighted them according to the proportion by dry mass of that prey type in the diet.

\section{Maintenance metabolism}

In 1981 , rate of oxygen consumption $\left(\mathrm{VO}_{2}\right)$ of $C$. tigris captured near the study plot was measured in the laboratory in a closed system (Vleck 1978). Nighttime $\mathrm{VO}_{2}$ at $30^{\circ}$ (a temperature approximating the average nightly burrow temperature at $13 \mathrm{~cm}$ underground) was measured for each lizard when fed (called maintenance metabolic rate, MMR) and when fasted (called standard metabolic rate, SMR: Bennett and Dawson 1976). We consider MMR to include (1) minimum maintenance cost, which is actually the same as SMR, and (2) the energy cost of digestion and assimilation of food energy, known as specific dynamic action (Bartholomew 1976). Our usual procedure was to capture lizards and fast them for $5 \mathrm{~d}$ in the laboratory, measure $\mathrm{VO}_{2}$, and then feed them mealworms and crickets ad libitum for $5 \mathrm{~d}$ and measure $\mathrm{VO}_{2}$ once more. Lizards were maintained in the laboratory on a $12 \mathrm{~L}: 12 \mathrm{D}$ photoperiod with a heat lamp to allow basking. All MMR measurements were made with lizards that we had observed to have eaten on the morning of the day of measurement. Because feeding was ad libitum, we may have been measuring the cost of production (either storage, growth, or reproduction) as well as MMR.

Lizards were weighed and placed into syringelike cylinders $\left(250-350 \mathrm{~cm}^{3}\right)$ in a controlled-temperature room $\left(30^{\circ} \pm 1^{\circ}\right)$. They rested quietly within $15 \mathrm{~min}$ and were always asleep prior to a measure of $\mathrm{VO}_{2}$. After $2 \mathrm{~h}$ the cylinders were sealed. Gas samples taken from the cylinders through three-way stopcocks at the beginning and end (50-100 min later) of an experimental run were injected into an Applied Electrochemistry $\mathrm{O}_{2}$ Analyzer after removal of water with Drierite and of $\mathrm{CO}_{2}$ with Ascarite. Fractional $\mathrm{O}_{2}$ levels in the chambers never declined below $19.0 \%$ (ambient $=$ $20.98 \%)$.

$\mathrm{VO}_{2}$ was calculated using Eq. 10 of Vleck (1978). Chamber volumes were corrected for volumes of the lizards. Initial $\mathrm{CO}_{2}$ concentration was taken as zero, and the fractional concentration of water vapor was 
calculated from measured relative humidity (Environmental Tectonics Corporation Psychro-dyne) and the water content of saturated air at $30^{\circ}: 0.038 \mathrm{~cm}^{3} / \mathrm{cm}^{3}$ water/air. All reported oxygen consumption volumes are corrected to conditions of standard temperature and pressure.

To determine the appropriate temperature for MMR during the activity period, we measured the body temperatures $\left(T_{\mathrm{b}}\right)$ of active lizards in the field. Lizards were noosed and deep-cloacal temperatures were measured with a Schultheis rapid-registering thermometer. Body temperature data were not used if animals fled prior to capture.

\section{Statistical analysis}

Numerical results throughout the text are given as mean \pm one standard error of the mean ( $n=$ number of animals); in some cases standard deviation is specified. The Student's $t$ test was used to compare means between groups. Analysis of covariance (ANCOVA: Dunn and Clark 1974) was used to compare the slopes and intercepts of linear regressions.

\section{RESULTS}

\section{Reproduction and body mass change}

During the 5-yr period, 1979-1983, females were found in reproductive condition (containing yolking follicles, oviductal eggs, or corpora lutea) from early April to early June. By mid-June no females were found in reproductive condition. There are exceptions to this scenario. For example, in 1984, a rare late-May rain apparently caused nearly all females to lay another clutch in June and July; in 1985 some very small females from the late clutch in 1984 were oviductal into late June and early July. Nevertheless, in most years, the reproductive season (composite for 1979-1983) beginning with emergence from hibernation to the capture of the last reproductively active female was $\approx 90$ $\mathrm{d}, \approx 15$ March-12 June. The mean time of emergence from hibernation for the population is several weeks earlier in warm weather, but usually during most of March lizard activity is only occasional. In 1979-1982 only one female was seen in reproductive condition past 1 June. The end of the reproductive season in 1983, however, extended to mid-June, perhaps due to larger clutches of the smaller lizards (relative to smaller, clutches of other years) and third clutches of larger lizards. This may in turn be because early winter rainfall resulted in greater annual and perennial plant production and hence greater insect availability than in 1979-1982 (R. A. Anderson, personal observation).

Patterns of change in body mass and length of adult C. tigris differed between males and females during the reproductive season. In males, two patterns of change were apparent, dependent upon age. Smaller 1st-yr males (born the previous summer, perhaps from second clutches and hence the youngest cohort) grew in length and mass (Fig. 1A). Linear and mass growth rates during spring for young males (mean initial mass \pm $\mathrm{SD}=16.2 \pm 1.9 \mathrm{~g}$; mean initial SVL $\pm \mathrm{SD}=82 \pm 1.9$ $\mathrm{mm})$ for the years $1979-1982(n=8)$ were: length $0.11 \pm 0.02 \mathrm{~mm} / \mathrm{d}$; mass $45 \pm 11 \mathrm{mg} / \mathrm{d}$. During these same years, larger 1st-yr males (perhaps hatched from first clutches of prior year) and 2nd-yr and older males (mean initial mass $\pm \mathrm{SD}=20.3 \pm 1.7 \mathrm{~g}$; mean initial $\mathrm{SVL} \pm \mathrm{SD}=90 \pm 3.5 \mathrm{~mm} ; n=16)$ grew very little $(0.03 \pm 0.01 \mathrm{~mm} / \mathrm{d}, n=14 ;-2 \pm 7 \mathrm{mg} / \mathrm{d}, n=16$; Fig. 1B). In 1983, however, all males grew: small males (mean initial mass $\pm \mathrm{SD}=10.9 \pm 1.4 \mathrm{~g}$; mean initial $\mathrm{SVL} \pm \mathrm{SD}=75 \pm 3.1 \mathrm{~mm} ; n=3)$ grew $0.23 \pm 0.009$ $\mathrm{mm} / \mathrm{d}, 109 \pm 15 \mathrm{mg} / \mathrm{d}$, and large males (mean initial mass $\pm \mathrm{SD}=23.3 \pm 3.0 \mathrm{~g}$; mean initial $\mathrm{SVL} \pm \mathrm{SD}=$ $93.4 \pm 3.7 \mathrm{~mm} ; n=10$ ) grew $0.07 \pm 0.01 \mathrm{~mm} / \mathrm{d}, 26 \pm$ $12 \mathrm{mg} / \mathrm{d}$.

In contrast to the slight changes in body masses of males, the body masses of individual females sequentially increased and decreased markedly during the reproductive season (Fig. 2A and B). Palpation of females indicated this up and down pattern resulted from gradual gains in mass during vitellogenesis, followed by sudden losses when eggs were laid. With the exception of 1983, females generally did not increase in body length during the reproductive season (a few immature and small adult females did grow). Complete cycles of mass changes (light-heavy-light) of individual females occurred in as little as $20 \mathrm{~d}$ (cf. female C; Fig. 2A). Rates of body mass increase during periods of egg growth and over intervals of $<25 \mathrm{~d}$ averaged $142 \pm$ $53 \mathrm{mg} / \mathrm{d}(n=7)$ in 1981 and 1982, and $217 \pm 62 \mathrm{mg} / \mathrm{d}$ $(n=7)$ in $1983(P>.2)$. For all years combined, the average rate of mass increase was $179 \pm 37 \mathrm{mg} / \mathrm{d}$ for females; their average initial body mass was $17.69 \pm$ $0.91 \mathrm{~g}(n=14)$.

Over the entire reproductive season females may have lost mass, but we do not know their masses when they first emerged from hibernation. When females were first captured they had been active for $2-4 \mathrm{wk}$ and had been undergoing vitellogenesis for some time (R. A. Anderson, personal observation). The body mass decrease of individual females weighed in early to midApril (most with large-yolked follicles) and again in early June was $2.32 \pm 0.36 \mathrm{~g}(n=9)$. This is an overestimate of the actual body mass decrease because it is apparent from the prior statement and from Fig. 2A that the females had been increasing in body mass for several weeks prior to their initial capture. Using the estimated $179 \mathrm{mg}$ of increase per day, then only $2 \mathrm{wk}$ of mass gain in a female prior to the first capture would negate any apparent decrease over the reproductive season, such that females would have begun and ended the reproductive season at the same body mass.

Because frequency of clutch production is an important parameter and we were not fortunate enough to gather sufficient direct evidence we must provide indirect evidence in some detail. The four following 

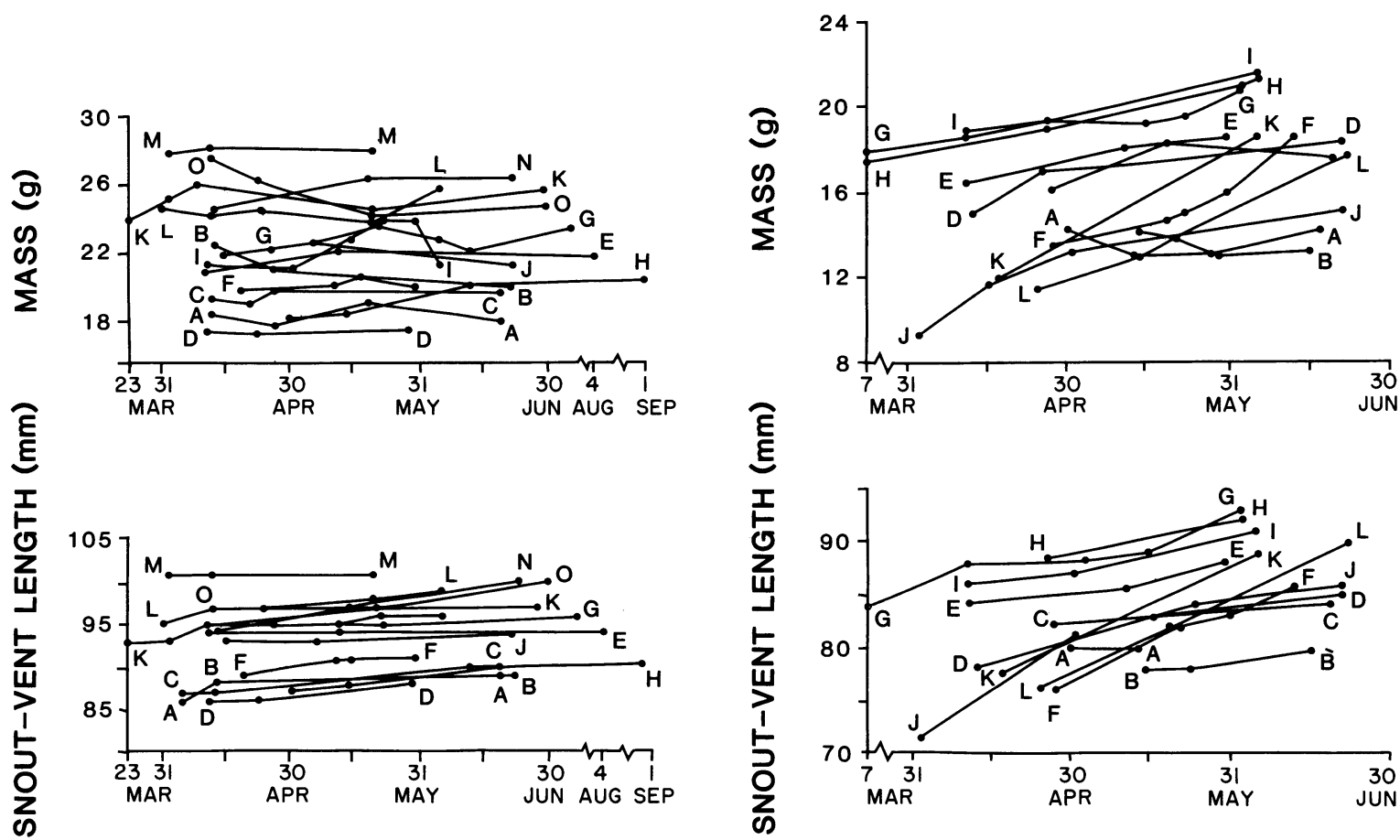

FIG. 1. Changes in body mass and snout-vent length of male Cnemidophorus tigris during the reproductive season. (A) shows larger, principally 2nd-yr or older, males from years 1979 to 1982. (B) shows smaller 1st-yr males from years 19791982. The points represent measurements made on particular individuals (identified by letters) on the date indicated on the abscissa. The slopes of the lines connecting points were used as estimates of rates of change in mass or length. Note that small males grew (i.e., increased in length and mass) whereas larger males did not.

lines of evidence indicate that female $C$. tigris laid two consecutive clutches during a single reproductive season.

First, patterns of body mass change in many females directly showed, or were indicative of, two consecutive cycles of body mass change, and are consistent with two consecutive clutches. The timing of female body mass changes revealed two principal periods of egg laying: mid-April and mid-May (Fig. 2A).

Anatomical evidence that females lay a second clutch in May (at least two clutches during the 2-3 mo reproductive season) includes the simultaneous occurrence in necropsied females of corpora lutea and small vitellogenic follicles: in 1 of 7 females with small fol licles ( $<8 \mathrm{~mm}$ diameter) in April and in 6 of 18 females in May. (Corpora lutea are vanishing by the time the next follicles begin to gain yolk: Christensen 1971, Cuellar 1984; R. A. Anderson, personal observation.)

Behavioral evidence that two clutches were oviposited in a short time span is based on the observation that males guard their mates only prior to ovulation and usually for only 1-3 d (Anderson 1986). Six females, with egg-laden abdomens (i.e., in near-ovulatory condition), bite marks on the abdomen indicative of copulation, and accompanied by males (mate guarding) were seen twice each at a mean interval of $22 \mathrm{~d}$ (range 15-33 d). The presumption of ovulatory condition is based on the observation that all autopsied females accompanied by males when captured $(n=8)$ had large-yolked follicles (10.9 $\pm 1.22 \mathrm{~mm}$ diameter). Also, five other visibly gravid females that had copulation bite marks and were accompanied by males were resighted between 4 and $17 \mathrm{~d}$ later (mean $=9 \mathrm{~d}$ ); all appeared thinner, with skin folds in the posterior part of the abdomen, and each had undergone a substantial mass decrease. Hence, they had oviposited. Furthermore, five females that were captured while gravid and that had fresh copulation bite marks (known not to be from prior reproductive episodes) were subsequently recaptured $8,8,6,6$, and $4 \mathrm{~d}$ later, and all had oviposited. Thus, though females oviposit within about a week of being accompanied by males, six females had been seen accompanied on two occasions separated by at least $15 \mathrm{~d}$ and hence had oviposited twice.

The fourth bit of evidence that females laid two clutches is that the majority of autopsied females (19801983) were in an advanced stage of reproduction (i.e., large yolking follicles, oviductal eggs, or corpora lutea) 
A. LARGER, 2ND -YR OR OLDER FEMALES

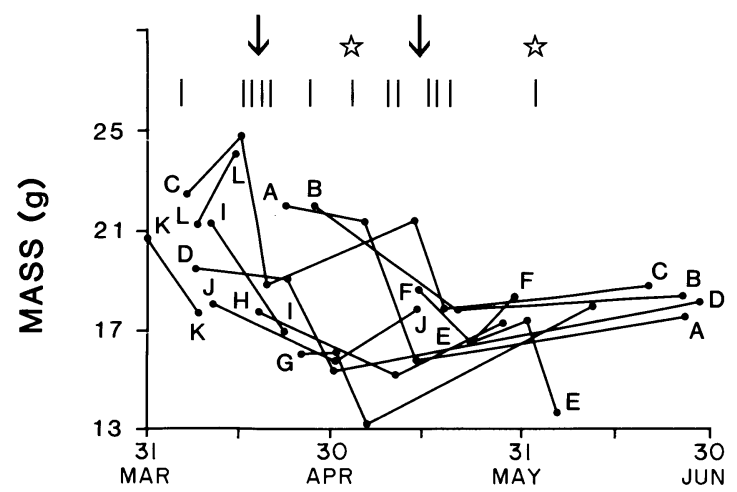

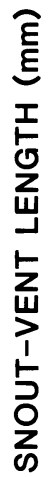

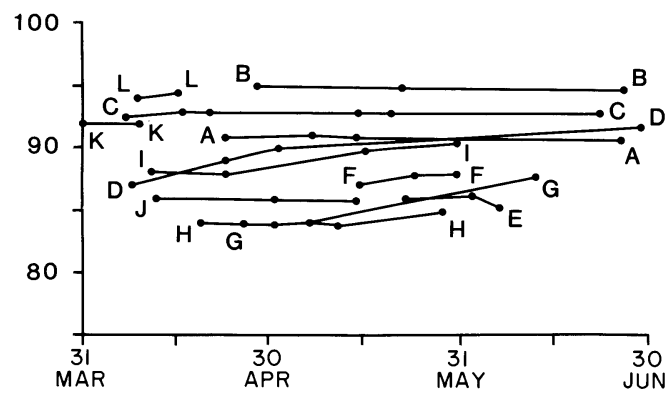

B. SMALLER, 1ST-YR FEMALES
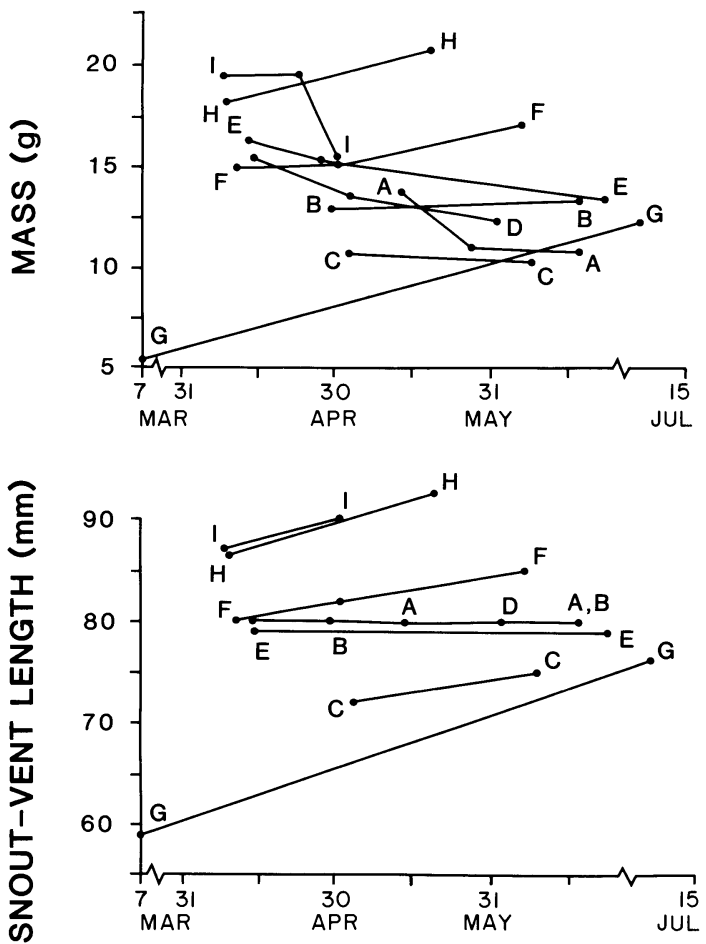

FIG. 2. Changes in body mass and snout-vent length of female Cnemidophorus tigris during the reproductive season. (A) shows larger, principally 2nd-yr or older, females from years 1979 to 1983 . (B) shows smaller 1 st-yr females from the same years. Note that females, especially the large ones, did not grow in length but underwent body mass changes indicative of egg production and laying. The short solid vertical lines in the body mass graph of A designate the estimated time (based on sudden mass decrease) at which individuals laid a clutch. These oviposition times are clustered into two groups, designated by an arrow. Two exceptions ( $(\tau)$ are indicated: an oviposition time for the smallest reproductive female in 1983, which occurred between the two peak oviposition times for the population; and a very late oviposition time, which may have been a third clutch of a large female.

in both April (11-30 April; 75\%, $n=32)$ and late May (22 May-7 June; 75\%, $n=28$ ). Given that females oviposit within a week of having large yolking follicles, it seems most females laid two clutches, and some perhaps laid three clutches.

Clutch size in females varied with time of laying (first or second clutch), body size, and year (Fig. 3). For all years taken together, clutch size was positively correlated with snout-vent length (SVL; $F_{1,53}=16.4, P<$ .005 ), and the relationship indicates that clutch size increased by one egg for every $17-\mathrm{mm}$ increase in length. Mean clutch size was significantly greater in the first clutch of 1983 ( $3.3 \pm 1.1$ eggs, $n=21$ clutches) than in the first clutch for the combined years 1980-1982 (2.3 \pm 0.6 eggs, $n=37$ clutches $)(P<.001$; two-tailed $t$ test), even though mean SVL was the same for both samples $(P>.5)$. Adjusted means of early clutches (those counted in April and up to 7 May) were significantly larger than for later clutches (22 May to 7 June) in the years $1980-1983(P<.005$; ANCOVA).

\section{Environmental conditions and lizard activity patterns}

Weather conditions during the labeled-water study period (12 April-4 May 1980) were such that lizards could be active the majority of the day for most days. Cnemidophorus tigris were seen active on the site each of the $14 \mathrm{~d}$ we were there. Environmental conditions were similar 8 of the other $10 \mathrm{~d}$ (United States Weather Bureau records, Eagle Mountain [ $8 \mathrm{~km}$ from site] and Hayfield Pumping Station [21 km from site]). Cnemidophorus tigris may not have been active on $2 \mathrm{~d}$ of inclement weather (30 April, cloudy; 1 May, cloudy and light rain).

Lizards were abundant above ground each of 14 mornings. Fewer lizards were seen in afternoons, but some were found to be active 10 of 13 early afternoons (1200-1300 Pacific Standard Time [PST]) and six of eight mid- to late-afternoon periods. We quantified lizard activity by calculating the number of lizards 


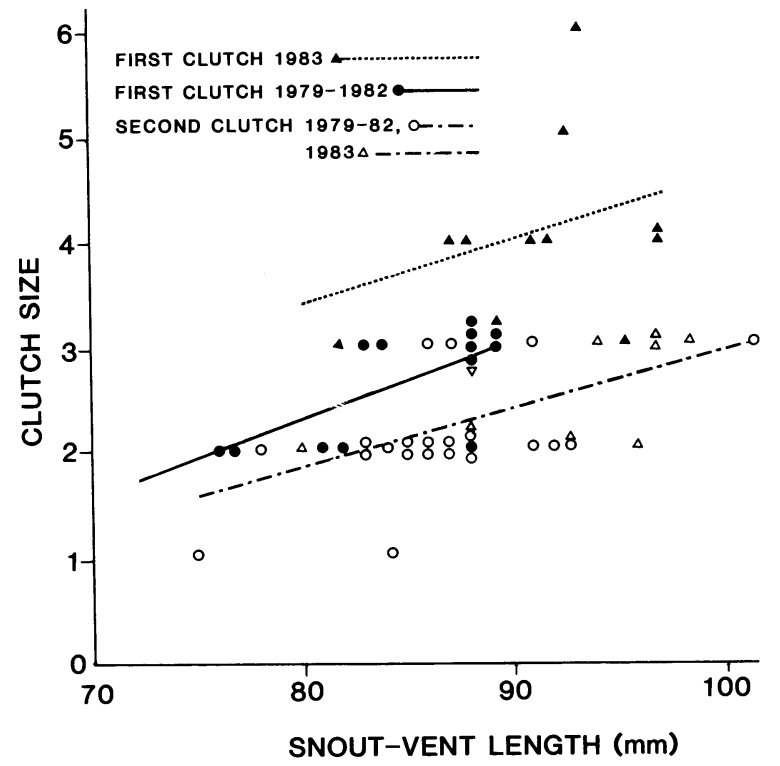

FIG. 3. Clutch size as a function of snout-vent length in Cnemidophorus tigris. Clutches measured early in the spring (April-7 May) are designated first clutches, while those measured later (22 May-7 June) are designated second clutches. Clutch size was significantly correlated with body length $\left(F_{1,53}=\right.$ $16.4, P<.005)$. First clutches in 1983 were significantly larger than in 1979-1982 $\left(F_{1,22}=8.34, P<.01\right)$, and first clutches for both periods were larger than second clutches $\left(F_{1,34}=16.8\right.$, $P<.005)$, which did not differ significantly between years. The three relationships do not differ in slope $\left(F_{3,50}=0.14\right.$, $P>.25$; common slope $=0.059$ )

sighted per person-hour of searching (Fig. 4). Lizard activity, measured in this manner, was highest between 0800 and 0900 (3.3 lizards/person-hour; $n=4.3$ person-hours searching over $5 \mathrm{~d}$ ) and decreased through the day. The average for the entire morning (08001200) was 2.6 lizards/h ( $n=21.6$ person-hours over 7 d), whereas that for the afternoon (1300-1700) was 1.6 lizards/h $(n=16.4$ person-hours over $6 \mathrm{~d})$. The pattern of activity in the postreproductive season differed from this pattern in the reproductive season. Although the morning sightings of lizards were as frequent in both seasons (3.6 lizards/h; $n=11.9$ person-hours over 6 d), in the postreproductive season the lizards were absent on the surface between 1100 and $1500(n=4.2$ person-hours over $3 \mathrm{~d}$ ) and then were seen at a low frequency ( 0.3 lizards/h; 20.5 person-hours over $10 \mathrm{~d}$ ) late in the afternoon (1500-1900).

The observations of activity during the reproductive season study period are in accord with our expectations based on thermal conditions (measured over $11 \mathrm{~d}$, late April to early May; Fig. 5). Cnemidophorus tigris emerge in the morning to bask when soil surface temperatures $\left(T_{\mathrm{ss}}\right)$ reach $\approx 30^{\circ}$. On four mornings for which we are confident that we began searching for $C$. tigris prior to their emergence, the range of $T_{\text {ss }}$ at first sighting (07200805) of a lizard was $30^{\circ}-35^{\circ}$. Cnemidophorus at this site do not have to retreat to burrows in late morning or early afternoon to avoid overheating while foraging unless $T_{\mathrm{ss}}$ is $\approx 55^{\circ}$ and air temperatures at $1 \mathrm{~m}\left(T_{\mathrm{m}}\right)$ are $\approx 35^{\circ}$ (R. A. Anderson, personal observation). These high temperatures did not occur during the study period. Thus, during April, lizards could potentially be active for $\approx 10 \mathrm{~h}$ in which $T_{\text {ss }}$ was above $30^{\circ}$, from early morning to late afternoon. Length of the potential activity period was somewhat shorter during the hotter days of May and was even shorter in June (Anderson and Karasov 1981).

Individual lizards were probably not out of their burrows for $10 \mathrm{~h} / \mathrm{d}$ but instead were abroad for a period in the morning and then possibly again in the afternoon. Sometimes during the $1 / 2$-h observation bouts $C$. tigris retreated to their burrows to end their "morning" activity period. Of 30 such observations between midApril and mid-May, the mean time of retreat was $3.6 \pm$ 0.2 h (i.e., $\approx 1045$ PST) after the estimated emergence time (i.e., when $T_{\text {ss }}$ first reached $30^{\circ}$ ). In five instances, the burrows of lizards that had retreated to them in the morning were excavated in midafternoon $(\approx 1600)$. In each case the lizard was present, and asleep, in the bottom of the burrow.

The behavioral data indicate that, as a population, C. tigris was seen throughout the day; and possibly some individuals were abroad for the entire activity period, but others clearly were not. Because most lizards were active in the morning, we can estimate a mean length of daily activity period by assuming an

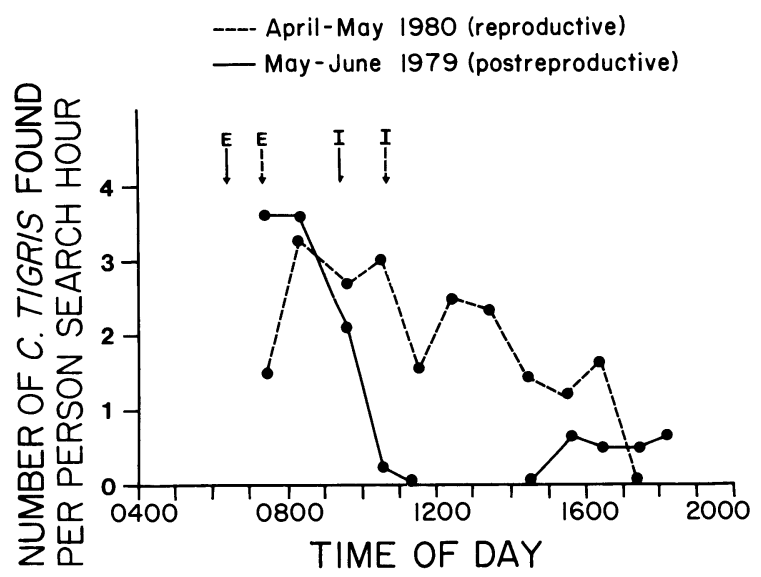

FIG. 4. Number of observations of Cnemidophorus tigris throughout the day during the reproductive and postreproductive season. Points represent the mean number of $C$. tigris observed per person-hour searching time during the Pacific Standard Time interval specified along the abscissa. Arrows designate estimated emergence times $(\mathrm{E}$, defined as the time at which soil surface temperature in the sun first reached $30^{\circ} \mathrm{C}$ ) and mean immergence times in the morning (I, based on observations of lizards). Dashed lines and arrows are for the reproductive season, solid lines and arrows are for the postreproductive season. During the reproductive season $C$. tigris were seen throughout the day, whereas during the postreproductive season observations of lizards had a bimodal distribution. 


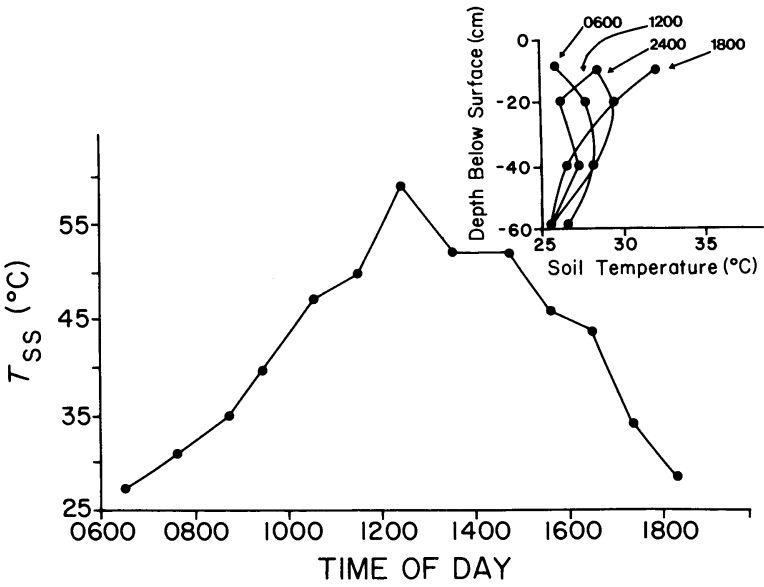

FIG. 5. Representative soil temperatures at the study site. Large figure shows average daytime soil surface temperatures in the sun $\left(T_{\mathrm{ss}}\right)$ (data for $11 \mathrm{~d}$ in April and May 1980). Inset shows soil temperature profile at four times of day, based on data for 6 d during April and May 1980.

additional short afternoon activity period (Fig. 4) and/ or a continuous full-day activity period for a few individuals. Thus, we estimate the number of hours active per day for our sample to have been $\approx 1 / 2-1 \mathrm{~h}$ more than the $3.5-\mathrm{h}$ morning activity period, hence $\approx 4-$ $4.5 \mathrm{~h}$.

When inactive, $C$. tigris are in burrows. Eleven burrows of $C$. tigris were excavated during the study period. Mean depth was $13 \pm 3 \mathrm{~cm}$, range was $9-20 \mathrm{~cm}$. Subsurface $(-13 \mathrm{~cm})$ soil temperatures during the period of inactivity (i.e., burrow occupancy, for 10-14 h; see Table 2), usually midday to the next morning, ranged from $25.5^{\circ}$ to $31.6^{\circ}$ (Fig. 5).

\section{Metabolism in the field and laboratory}

We measured $\mathrm{CO}_{2}$ production of adults during midApril to early May, coincident with vitellogenesis, mat- ing, and oviposition (Fig. 2A). The size ranges of males used were 15.9-22.5 g, and 78-89 $\mathrm{mm} \mathrm{SVL}$. The size ranges of females used were 12.9-19.9 $\mathrm{g}$ and 76-86 $\mathrm{mm}$ SVL. The means of body mass and length were significantly greater in males than in females among the labeled lizards in the field (Table 1).

Daily $\mathrm{CO}_{2}$ production, as measured by the doubly labeled water method, was significantly greater in males than females on a whole-animal basis (cubic centimetres per day). This difference was due, in part, to the inequality in body masses between the sexes, and to a significant difference in mass-specific field metabolism. The ln of FMR was linearly related to the ln of body mass (pooled slope $=0.69$ ), but the $y$ intercept of the regression line for males was $\approx 27 \%$ greater than that of females $(P=.05$; ANCOVA).

The average rates of $\mathrm{CO}_{2}$ production per gram of body mass were converted to the energy equivalent, joules per gram per day, which we term field metabolic rate (FMR). These values are: males, $298 \mathrm{~J} \cdot \mathrm{g}^{-1} \cdot \mathrm{d}^{-1}$; females, $247 \mathrm{~J} \cdot \mathrm{g}^{-1} \cdot \mathrm{d}^{-1}$. The term FMR is equivalent to daily energy expenditure (DEE) in Anderson and Karasov (1981) and Karasov and Anderson (1984). FMR can be considered the summation of several components of energy expenditure.

We measured the components of energy use associated with standard metabolism and digestion of food (specific dynamic action) in the laboratory. Metabolic rates per whole animal (oxygen consumption, $\mathrm{VO}_{2}$ ) were similar in fed, resting $C$. tigris males and females at $30^{\circ}$ (maintenance metabolic rate, MMR; Table 1). We measured the metabolic rate of fasted, resting lizards (standard metabolic rate, SMR) at $30^{\circ}$ to permit comparison with published values (Asplund 1970) of SMR in postreproductive C. tigris (see Discussion: I. Energy Budgets of Cnemidophorus tigris: Maintenance Costs during Reproduction). All lizards in our measurements of $\mathrm{VO}_{2}$ were not only resting, but they appeared to be asleep. Comparisons of SMR and MMR

TABLE 1. Body mass and rates of $\mathrm{CO}_{2}$ production in the field and $\mathrm{O}_{2}$ consumption $\left(\mathrm{VO}_{2}\right)$ in the laboratory in Cnemidophorus tigris during the reproductive season $(\bar{X} \pm \mathrm{SE})$. Number of lizards is given in parentheses.

\begin{tabular}{|c|c|c|c|}
\hline & Males & Females & $P^{*}$ \\
\hline Field & 10 & & \\
\hline $\begin{array}{l}\text { Body mass }(\mathrm{g}) \\
\text { Change in mass }(\% / \mathrm{d}) \\
\mathrm{CO}_{2} \text { production }\left(\mathrm{cm}^{3} / \mathrm{d}\right)\end{array}$ & $\begin{aligned} 18.8 & \pm 0.8(10) \\
+0.1 & \pm 0.1 \\
219 & \pm 11\end{aligned}$ & $\begin{aligned} 15.8 & \pm 1.1 \\
-0.7 & \pm 0.1 \\
156 & \pm 10\end{aligned}$ & $\begin{array}{l}<.05 \\
<.01 \\
<.005\end{array}$ \\
\hline Laboratory resting $\left(30^{\circ} \mathrm{C}\right)$ & & & \\
\hline Fed lizards & $20.32 \pm 0.56$ & $15.19 \pm 1.11$ & $<.005$ \\
\hline $\begin{array}{l}\left(\mathrm{cm}^{3} / \mathrm{h}\right) \\
\left(\mathrm{cm}^{3} \cdot \mathrm{g}^{-0.8} \cdot \mathrm{h}^{-1}\right)\end{array}$ & $\begin{array}{l}3.54 \pm 0.42 \\
0.32 \pm 0.04\end{array}$ & $\begin{array}{l}3.07 \pm 0.51 \\
0.34 \pm 0.04\end{array}$ & $\begin{array}{l}>.4 \\
>.5\end{array}$ \\
\hline $\begin{array}{l}\text { Fasted lizards } \\
\text { Body mass (g) } \\
\mathrm{O}_{2} \text { consumption, SMR }\end{array}$ & $19.13 \pm 0.80$ & $14.18 \pm 1.03$ & $<.01$ \\
\hline 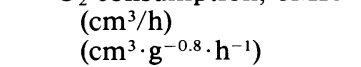 & $\begin{array}{l}2.28 \pm 0.07 \\
0.22 \pm 0.01\end{array}$ & $\begin{array}{l}1.74 \pm 0.12 \\
0.22 \pm 0.01\end{array}$ & $\begin{array}{l}<.005 \\
>.5\end{array}$ \\
\hline
\end{tabular}

\footnotetext{
$* t$ test comparing values for the two sexes.
} 
TABLE 2. Estimation of rates of energy expenditure during the resting period (RPMR) and the activity period (APMR) in free-living Cnemidophorus tigris males and females during the reproductive season.*

\begin{tabular}{|c|c|c|c|c|c|}
\hline & \multicolumn{2}{|c|}{$\begin{array}{l}\text { Longest } \\
\text { activity } \\
\text { period }\end{array}$} & \multicolumn{2}{|c|}{$\begin{array}{l}\text { Shortest } \\
\text { activity } \\
\text { period }\end{array}$} & \multirow{2}{*}{ - $\begin{array}{c}\text { No } \\
\text { activity }\end{array}$} \\
\hline & $\hat{\delta} \hat{\jmath}$ & $\$ 9$ & 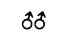 & 99 & \\
\hline Activity period $(\mathrm{h} / \mathrm{d})$ & 10 & 10 & 4 & 4 & 0 \\
\hline FMR $†\left(J \cdot g^{-1} \cdot d^{-1}\right)$ & 298 & 247 & 298 & 247 & 76 \\
\hline $\operatorname{RPMR}\left(\mathrm{J} \cdot \mathrm{g}^{-1} \cdot \mathrm{d}^{-1}\right)$ & 129 & 129 & 99 & 99 & 76 \\
\hline $\operatorname{APMR}\left(J \cdot \mathrm{g}^{-1} \cdot \mathrm{d}^{-1}\right)$ & 169 & 118 & 199 & 148 & 0 \\
\hline
\end{tabular}

* Calculations are for the maximum $(10 \mathrm{~h})$ estimated daily activity period length, for the minimum, and probable, length $(4 \mathrm{~h})$, and also for a hypothetical lizard remaining in a $13 \mathrm{~cm}$ deep burrow.

† FMR measured with doubly labeled water.

within individual $C$. tigris revealed SMR to be $0.70 \pm$ 0.05 of MMR $(n=10$, sexes pooled, $P<.005$ by paired $t$ test).

Maintenance metabolic rates of $C$. tigris measured in the laboratory were used to partition FMR into resting and active components. The daily cost of resting in burrows (called the resting period metabolic rate, RPMR) was estimated by integrating temperature-dependent MMR calculated from our measurements of MMR at $30^{\circ}$ and published $Q_{10}$ s (rate change in MMR for every $10^{\circ}$ change in $T_{\mathrm{b}}$ : Asplund 1970) over the temperature in the burrow during the resting period (Fig. 5). The difference between FMR and RPMR is called active period metabolic rate (APMR). The APMR can be attributed to the energy expended into (1) metabolism of a fed lizard while resting at field active body temperature, $\approx 40^{\circ}\left(T_{\mathrm{b}}=40.4^{\circ} \pm 0.2^{\circ}, n=40\right)$, and (2) the daily cost of activity (alertness, locomotion, etc.), which is the difference between total energy expended during the activity period and the energy expenditure associated with resting at $40^{\circ}$.

We have estimated the length of daily activity to be at least $4 \mathrm{~h}$, given an afternoon activity period of short, but undetermined, length. We know that $C$. tigris were not active every day of the labeling period; e.g., the 1$2 \mathrm{~d}$ of inclement weather. Therefore, we have made several calculations and performed a sensitivity analysis of the proposed energy budget (Table 2).

Whether we assume that $C$. tigris were active with a body temperature of $40^{\circ}$ for the maximum number of hours possible each day $(10 \mathrm{~h})$ or for the minimum, and probable, number $(4 \mathrm{~h})$, the extremes of calculated RPMR differ by only $30 \%$ for both males and females. Estimates for the extremes of APMR differ by only $18 \%$ for males and $25 \%$ for females. We also calculated the RPMR for a hypothetical lizard remaining in its burrow $24 \mathrm{~h} / \mathrm{d}$ to determine an absolute lower limit for the RPMR estimate, which is $76 \mathrm{~J} \cdot \mathrm{g}^{-1} \cdot \mathrm{d}^{-1}$. If lizards were active for 4 or $10 \mathrm{~h} / \mathrm{d}$ for only some proportion of the total number of days, their RPMR would lie between this lower value and the values estimated for 4 or $10 \mathrm{~h} / \mathrm{d}$. These calculations demonstrate that our estimated RPMR of $99 \mathrm{~J} \cdot \mathrm{g}^{-1} \cdot \mathrm{d}^{-1}$ is within $30 \%$ of the actual RPMR of male and female $C$. tigris regardless of our assumptions about the length of the daily activity period or proportion of days active. Therefore, in the subsequent discussion we take this value $\left(99 \mathrm{~J} \cdot \mathrm{g}^{-1} \mathrm{~d}^{-1}\right)$ as the RPMR of $C$. tigris during the reproductive season.

Because the minimum estimate of APMR for males is above the maximum APMR estimate for females (Table 2), APMR of males probably exceed those of females during the reproductive season. The APMR estimates of $199 \mathrm{~J} \cdot \mathrm{g}^{-1} \cdot \mathrm{d}^{-1}$ for males and 148 for females, based on a $4-h$ activity period and calculated as the measured FMR minus the estimated RPMR are within $\approx 15$ and $25 \%$, respectively, of the true activity cost of males and females. In the subsequent discussion we take these values as the costs accrued during one daily activity period of $C$. tigris in the reproductive season.

\section{Diet}

Stomach contents in 1981 for the same period of study (late April) as in 1980, showed 17 males and 5 females to have similar diets. The same three orders of arthropods (Isoptera, Lepidoptera, and Homoptera) made up $77 \%$ of the prey by number in males and $88 \%$ in females (Table 3). Lepidopteran larvae, because of their large size, were the most important prey type by mass. Lepidopteran larvae also have a considerably higher water content than most other prey types. Thus, the estimated diet water content, $3.12 \mu \mathrm{L} / \mathrm{mg}$ dry mass (or $75.7 \%$ water), is higher than the water content of most other prey types $C$. tigris ate. We previously estimated the diet water content of $C$. tigris during summer to be $\approx 70 \%$ (Anderson and Karasov 1981). At that time of year, however, the most important prey types are arthropods with lower water contents than lepidopteran larvae (e.g., termites, solpugids, and beetles).

Observations of behavior (late April-early May 1980) revealed similar prey capture rates for both sexes via the same capture methods: prey capture by digging (males $62 \%$ of prey, $n=14$ males, 29 prey; females $58 \%, n=14,32$ prey) and prey capture on surface (males $38 \%$, females $41 \%$ ). The number of successful prey capture bouts per hour of foraging was also similar: males 4.0 bouts $/ \mathrm{h}(n=14$ males, $420 \mathrm{~min}$ total observation time, 30 min mean observation time per lizard), females 4.3 bouts/h $(n=14$ females, $458 \mathrm{~min}$ total, 33 min mean).

These data on male and female diets and prey capture rates can be interpreted to mean (1) diet water contents of males and females were similar, and (2) males and females had similar rates of food intake per day. In the next section we calculate and more directly compare the feeding rates of $C$. tigris males and females using water turnover rate. Those data also indicate 
TABLE 3. Arthropod prey in the stomachs of 22 Cnemidophorus tigris ( 17 males, 5 females) during the reproductive season.*

\begin{tabular}{|c|c|c|c|c|c|c|c|c|c|}
\hline \multirow[b]{2}{*}{ Taxa } & \multirow{2}{*}{$\begin{array}{c}\text { Life } \\
\text { stage }\end{array}$} & \multirow{2}{*}{$\begin{array}{c}\text { Total } \\
\text { no. prey }\end{array}$} & \multicolumn{2}{|c|}{$\begin{array}{l}\text { Proportion } \\
\text { by number }\end{array}$} & \multicolumn{2}{|c|}{$\begin{array}{l}\text { Prey length } \\
\quad(\mathrm{mm})\end{array}$} & \multirow{2}{*}{$\begin{array}{c}\text { Estimated } \\
\text { dry mass } \\
\text { of } 1 \text { prey } \\
(\mathrm{mg})\end{array}$} & \multirow{2}{*}{$\begin{array}{l}\text { Propor- } \\
\text { tion } \\
\text { of prey } \\
\text { in diet, } \\
\text { dry mass }\end{array}$} & \multirow{2}{*}{$\begin{array}{c}\text { Dietary } \\
\text { water } \\
\text { content } \\
(\mu \mathrm{L} / \mathrm{mg}) \\
\text { of dry } \\
\text { mass }\end{array}$} \\
\hline & & & $\hat{o}$ & ? & $\bar{X} \pm \mathrm{sD}$ & (Range) & & & \\
\hline Isoptera & $\mathbf{a}$ & 309 & .38 & .72 & $3.5 \pm 0.2$ & $(2.75-4)$ & 386 & 0.16 & 2.53 \\
\hline Lepidoptera & 1 & 125 & .27 & .10 & $12 \pm 4$ & $(5-21)$ & 1068 & 0.44 & 4.29 \\
\hline Homoptera & $a / n$ & 74 & .13 & .06 & $4 \pm 1$ & $(2-5)$ & 106 & 0.04 & 2.17 \\
\hline \multirow[t]{2}{*}{ Coleoptera } & 1 & 32 & .04 & .03 & $7 \pm 4$ & $(3-18)$ & 110 & 0.05 & 2.09 \\
\hline & $\mathbf{a}$ & 25 & .05 & .02 & $6 \pm 2$ & $(2-11)$ & 148 & 0.06 & 1.86 \\
\hline Araneida & $a / n$ & 22 & .06 & .05 & $2 \pm 1$ & $(1-5)$ & 19 & 0.01 & 3.61 \\
\hline Orthoptera & $a / n$ & 15 & .04 & .01 & $10 \pm 5$ & $(4-24)$ & 339 & 0.14 & 1.89 \\
\hline Neuroptera & $a / n$ & 13 & .03 & .01 & $7 \pm 1$ & $(4-7)$ & 45 & 0.02 & 2.33 \\
\hline Solpugida & $a / n$ & 4 & .01 & .01 & $16 \pm 3$ & $(13-20)$ & 196 & 0.08 & 2.17 \\
\hline Weighted mean & & & & & & & & & 3.12 \\
\hline
\end{tabular}

* Body lengths of prey were measured, and dry masses were calculated as described in Methods: Diet. Water content of the diet was estimated by weighting the water content of each prey type (obtained from the literature) by the proportion by mass of that prey type in the diet. Sources for water contents of prey types were: all types (Edney 1977, Sage 1982); Coleoptera, Orthoptera, and Lepidoptera (Morton 1973); Orthoptera (Appel et al. 1983); Isoptera (Collins 1969).

$+\mathrm{a}=$ adults, $\mathrm{n}=$ nymphs, $\mathrm{l}=$ larvae.

similar feeding rates by males and females, given that the amounts of water contained in the food of males and females were similar.

\section{Water influx}

Total water influx per individual lizard and per gram body mass did not differ significantly between males and females (Table 4). Rate of water influx potentially can be used as a measure of rate of food intake, or used to calculate it (Nagy and Shoemaker 1975, Anderson and Karasov 1981, Congdon et al. 1982b, Karasov and Anderson 1984). The water influx rate measured with labeled hydrogen includes influx due to: (1) ingestion of free (preformed) water in food, or (2) by drinking; and (3) production of water by catabolism of fats, carbohydrates, and proteins (i.e., metabolic water). Metabolic water production calculated from FMR (as described in Methods: Rates of Field Metabolism and Water Influx) equalled $8 \pm 1 \mu \mathrm{L} \cdot \mathrm{g}^{-1} \cdot \mathrm{d}^{-1}(n=16$, both sexes) or $12 \pm 1 \%$ of total water influx. Cnemidophorus tigris apparently drank little or no water, even though some standing water may have been available to drink on one cool cloudy day late in the study. Rate of total water influx in 10 lizards that were recaptured and resampled prior to the rain $\left(62 \pm 8 \mu \mathrm{L} \cdot \mathrm{g}^{-1} \cdot \mathrm{d}^{-1}\right)$ was the same as in eight lizards that were recaptured and resampled after the rain $\left(57 \pm 7 \mu \mathrm{L} \cdot \mathrm{g}^{-1} \cdot \mathrm{d}^{-1} ; P>.2\right.$; $t$ test). Therefore, as an approximation of water influx via food, we will use the difference between total influx and metabolic water production. This difference, herein termed "apparent food water influx," did not differ significantly between males and females (Table 4).

Metabolizable energy intake rates were calculated from water turnover data in two different ways, which were in close agreement. In the first method, apparent food water influx rates of lizards were divided by the average water content of the diet $(3.12 \mu \mathrm{L} / \mathrm{mg})$ to calculate dry mass feeding rates. These rates were converted to metabolizable energy intake rates by assuming that arthropod prey have an energy content of 23

TABLE 4. Body mass and water influx in free-living Cnemidophorus tigris during the reproductive season $(\bar{X} \pm \mathrm{SE})$. Number of lizards is given in parentheses.

\begin{tabular}{|c|c|c|c|}
\hline & Males & Females & $P^{*}$ \\
\hline Body mass (g) & $18.9 \pm 0.7 \quad(10)$ & $15.8 \pm 1.0$ & $<.025$ \\
\hline $\begin{array}{l}\text { Total } \mathrm{H}_{2} \mathrm{O} \text { influx } \\
(\mu \mathrm{L} / \mathrm{d}) \\
\left(\mu \mathrm{L} \cdot \mathrm{g}^{-1} \cdot \mathrm{d}^{-1}\right)\end{array}$ & $\begin{aligned} 1140 & \pm 40 \\
61 & \pm 2\end{aligned}$ & $\begin{aligned} 1060 & \pm 80 \\
66 & \pm 3\end{aligned}$ & $\begin{array}{l}>.5 \\
>.5\end{array}$ \\
\hline $\begin{array}{l}\text { Food } \mathrm{H}_{2} \mathrm{O} \text { influx } \dagger \\
(\mu \mathrm{L} / \mathrm{d}) \\
\left(\mu \mathrm{L} \cdot \mathrm{g}^{-1} \cdot \mathrm{d}^{-1}\right)\end{array}$ & $\begin{aligned} 994 & \pm 41 \\
53 & \pm 2\end{aligned}$ & $\begin{aligned} 934 & \pm 70 \\
59 & \pm 3\end{aligned}$ & $\begin{array}{l}>.5 \\
>.5\end{array}$ \\
\hline $\begin{array}{l}\text { Food } \mathrm{H}_{2} \mathrm{O} \text { influx } \\
\text { per unit FMR }(\mu \mathrm{L} / \mathrm{kJ})\end{array}$ & $0.18 \pm 0.01(10)$ & $0.22 \pm 0.01(7)$ & $<.05$ \\
\hline $\begin{array}{l}\text { Metabolizable energy intake } \\
\text { per unit FMR }(\mu \mathrm{L} / \mathrm{kJ})\end{array}$ & $1.00 \pm 0.06(10)$ & $1.24 \pm 0.06(7)$ & $<.05$ \\
\hline
\end{tabular}

$* t$ test comparing values for the two sexes.

$\dagger$ Food $\mathrm{H}_{2} \mathrm{O}$ influx = total $\mathrm{H}_{2} \mathrm{O}$ influx minus metabolic $\mathrm{H}_{2} \mathrm{O}$ production. This is an apparent food $\mathrm{H}_{2} \mathrm{O}$ influx; see Results: Water Influx for explanation. 
$\mathrm{J} / \mathrm{mg}$ dry mass (Nagy 1982 ) of which $85 \%$ can be metabolized (i.e., digested, absorbed, and catabolized: P. Lehrer and W. H. Karasov, personal observation). Metabolizable energy intake rates calculated by Method 1 were $332 \mathrm{~J} \cdot \mathrm{g}^{-1} \cdot \mathrm{d}^{-1}$ for males and $351 \mathrm{~J} \cdot \mathrm{g}^{-1} \cdot \mathrm{d}^{-1}$ for females. (Note: In these calculations we use the water influx rates of the seven females for which we had also made an FMR determination. The apparent food water influx rate of this subset of the females listed in Table 4 was $56 \pm 3 \mu \mathrm{L} \cdot \mathrm{g}^{-1} \cdot \mathrm{d}^{-1}$.)

The second method for measuring metabolizable energy intake takes advantage of the fact that males were in mass steady state (mass change $=-0.1 \pm 0.4 \% / \mathrm{d}$, $n=10$ ), and protein-fat-carbohydrate proportions were probably also fairly constant since growth in SVL was also negligible (Fig. 1). Metabolizable energy intake in these males can be taken to equal their energy expenditure $\left(298 \mathrm{~J} \cdot \mathrm{g}^{-1} \cdot \mathrm{d}^{-1}\right.$; Table 2$)$. We can therefore use the ratio of FMR to apparent food water influx in the males $\left(298 \mathrm{~J} \cdot \mathrm{g}^{-1} \cdot \mathrm{d}^{-1} / 53 \mu \mathrm{L} \cdot \mathrm{g}^{-1} \cdot \mathrm{d}^{-1}=5.62\right)$ to calculate the metabolizable energy intake rate $(\mathrm{M})$ of the females: $M=$ apparent food water influx $\times 5.62$. Thus, by Method 2 the metabolizable energy intake rates of males and females are, respectively, $298 \mathrm{~J} \cdot \mathrm{g}^{-1} \cdot \mathrm{d}^{-1}$ and $315 \mathrm{~J} \cdot \mathrm{g}^{-1} \cdot \mathrm{d}^{-1}$.

The $10 \%$ discrepancy between estimates of metabolizable energy intake by the two methods could be due to errors in our assumed values for diet water content, the metabolizable energy content of prey, or to a small amount of vapor influx for which we have not accounted. (The water vapor influx measured with labeled hydrogen results from the input, isotopic equilibration, and subsequent loss of externally supplied water vapor across the lungs and skin of animals [Nagy and Costa 1980].)

Note that female $C$. tigris were previously found to have lower rates of energy expenditure (Tables 1 and 2 ), but here are found to have similar or greater rates of apparent food water influx and hence metabolizable energy intake. It follows that the ratio of either food water influx, or metabolizable energy intake, to energy expenditure will be greater in females than in males (Table 4). This greater ratio in females than in males corroborates our general observations that females make eggs whereas many males show no growth during the spring. The smaller 1st-yr males grow during the spring and one would expect their ratio of apparent food water influx to FMR also to be greater than for large males. The body size range of males in our data set is inadequate for testing this idea that smaller lizards may show energy profit (gain mass), whereas larger lizards may only maintain (or even lose) mass, given that food intake per individual is the same.

\section{Behavior}

We compared the behavior of males and females to determine whether there were any obvious differences between them in locomotory activity that may have resulted in the differences in FMR. Observations made during the study ( $n=14$ males, 420 min total observation time; $n=14$ females, 458 min total observation time; mean observation time per individual 30 and 33 min, respectively) showed that the percent of total observation time spent in locomotory movement (males $89 \%$, females $84 \%$ ), the percent of time motionless (males 11\%, females 16\%), and the percent of total time digging ( $8 \%$ for both sexes) were all similar ( $t$ test, $P>$ $.05)$. But, mean velocity, or the total distance moved by an individual during a 30 -min observation period, was significantly greater in males, who were foraging for both food and mates (121 $\pm 14 \mathrm{~m}, n=10)$, than in females, who were foraging for food only (64 \pm 8 $\mathrm{m}, n=12)(P<.005)$. During the postreproductive season (June) males and females moved equivalent distances per 30-min observation period $(76 \pm 14 \mathrm{~m}$, $n=12$ and $77 \pm 14 \mathrm{~m}, n=10$, respectively; Anderson 1986), but females moved significantly less distance than males during the reproductive season $(P<.05$; Anderson 1986). Commensurate with these behavioral differences between the sexes in the two seasons, there was no signficant difference between the sexes in FMR during the postreproductive season (Anderson and Karasov 1981), and FMR at this time was significantly lower than during the reproductive season ( $t$ test, $P<$ .001 , on ln-transformed data).

The pattern of males moving more and faster is not surprising, given that their home ranges are larger than females' ( 1.4 and 0.4 ha, respectively), their polygynous mating system, and their nonterritoriality (Anderson 1986). We think the larger males, especially, spend some time and effort searching for females with which to monitor sexual condition and initiate courtship. In 58 of 328 sightings of females in the 1979-1983 reproductive seasons, the females were accompanied by males. We emphasize larger males because 27 of 31 identified males accompanying females were larger than the mean size of adult males in the population (Anderson 1986). Small males are rarely seen accompanying females. We will discuss the possible consequences to energetics and growth resulting from this pattern of body-size-related behavior in males.

\section{DISCUSSION}

We focus in this discussion on four central issues. First, we compare the pattern and magnitude of energy expenditure by Cnemidophorus tigris during the reproductive and postreproductive seasons. The second issue is related to the observation that lizards with wideforaging predation modes have been shown to have higher net rates of energy gain while foraging than lizards that are ambush predators (Anderson and Karasov 1981, Andrews 1984, Nagy et al. 1984). Thus, we investigate the hypotheses that wide foragers may have (1) equivalent or higher rates of egg laying than ambushers, in spite of lower relative clutch mass (RCM) in wide foragers, and (2) higher rates of production 
(growth, storage, and reproduction). Third, we calculate reproductive effort (RE) in $C$. tigris and compare it with RE calculated for other sympatric lizards, all of which are ambushers in the family Iguanidae. Finally, we evaluate the following measures of reproduction: RE, RCM, rate of production, and rate of egg laying. For each measure we consider the requisite data, the measure's potential use in understanding the evolutionary bases to life history adaptations, and the extent to which food-acquisition mode might ultimately affect each particular measure of reproduction.

\section{Energy budgets of Cnemidophorus tigris}

Energy budgets of free-living $C$. tigris were derived on the basis of the relation $M=R+P$ where $M$ is the metabolizable energy ingested, $R$ is the energy used for respiration (the sum total of all cellular respiration of the body, i.e., $\mathrm{VO}_{2}$ or FMR) and $P$ (production) is energy allocated to, or removed from, storage in the body. Respiration (FMR) was measured with doubly labeled water and is discussed first, followed by a discussion of production.

Total metabolism. - The FMR of $C$. tigris during the reproductive season $\left(247 \mathrm{~J} \cdot \mathrm{g}^{-1} \cdot \mathrm{d}^{-1}\right.$ for females, 298 for males) is $18-42 \%$ higher than during the postreproductive season (210 for both females and males: Anderson and Karasov 1981). We now consider whether this seasonal difference in FMR represents a metabolic cost of reproduction. This metabolic cost might include: (1) the energy cost of production associated with the conversion of food into eggs, (2) the energy cost of courtship, competition for mates, nesting, and the increased foraging effort necessary to supply energy for these activities (Congdon et al. 1982a), and (3) the cost of processing the increased amount of food (SDA).

Maintenance costs during reproduction. - The maintenance metabolic rate of a female lizard that is producing eggs would, a priori, be expected to be higher than that of males or a female that is not producing eggs (Parry 1983). Yet, we found no difference (ANCOVA) between sexes in either MMR or SMR per gram body mass during the reproductive season (Table 1). Furthermore, our values for SMR in reproductive C. tigris are slightly lower, not higher, than Asplund's (1970) values for nonreproductive $C$. tigris. Either the expected increase in oxygen consumption in gravid females is not measurable, or males also have increased resting metabolic rates (a hormonal effect?); also, technical differences between our measurements and Asplund's make comparisons problematical. We have also been unable to measure a difference in MMR between reproductive and postreproductive Callisaurus draconoides (R. A. Anderson and W. Karasov, personal observation).

Activity period costs during reproduction.-During the breeding season activity period metabolic rates (APMR) of C. tigris were estimated to be 199
$\mathrm{J} \cdot \mathrm{g}^{-1} \cdot \mathrm{d}^{-1}$ for males and 148 for females (Table 2 ). These values are twice the APMR of the postreproductive season for males $\left(95 \mathrm{~J} \cdot \mathrm{g}^{-1} \cdot \mathrm{d}^{-1}\right.$ for both sexes: Anderson and Karasov 1981) and 50\% higher for females. The seasonal differences might be due to (1) more days active during the reproductive season (2) more intense activity per hour active during the reproductive season, and (3) a longer daily activity period during the climatically equable reproductive season.

The first explanation is not supported by available data; the maximum number of lizards seen per hour was similar during both seasons (see peak activity in Fig. 4), which indicates similar number of lizards active each day (given similar population densities among years; Anderson 1986). Behavioral data support the second two possibilities: (1) male $C$. tigris move more and faster during the reproductive season than during the postreproductive season (see Results: Behavior), and (2) we saw lizards active on afternoons during the cooler reproductive season, whereas they were absent from the surface during most of the hot afternoons in the postreproductive season (Fig. 4).

Similarly, in Cnemidophorus hyperythrus, differences in activity period length seem to account for most of the observed differences in APMR and FMR (Karasov and Anderson 1984). In fact, in all studies of FMR of Cnemidophorus (two species in three habitats), we have found that FMR fits a relationship based on length of daily activity period: FMR (in $\mathrm{J} \cdot \mathrm{g}^{-0.80}$. $\left.\mathrm{d}^{-1}\right)=165+36.6$ (time abroad, in hours per day) $\left(r^{2}=\right.$ $0.91, P<.025)$. Merker and Nagy (1984) similarly have found a positive relationship between FMR and activity period length in Sceloporus virgatus. Thus, if the greater length of activity period during the reproductive season is associated with reproduction, then the corresponding difference in FMR between reproductive and postreproductive seasons may be tentatively considered a reproductive cost.

If $C$. tigris spend more time active during the reproductive season, is it because of a lower rate of prey capture than in the postreproductive season and, thus, that they must spend more time foraging during the reproductive season? We think not. Arthropods are more abundant in spring than summer in the Chuckwalla Valley (Anderson 1986, 1988). We have shown that $C$. tigris maintain constant body mass, foraging only 3-5 h/d (Fig. 4) during the early part of the postreproductive season (Anderson and Karasov 1981). The shorter activity periods of the postreproductive season may be caused by satiation or restrictive high ambient temperatures. Prey size was similar during both seasons and prey capture per hour of observation was insignificantly higher during the reproductive season of 1980 than during the postreproductive season of 1979 (respectively, 4.2 prey capture bouts/h observation, $n=28$ lizards, 64 bouts and 3.6 bouts/h, $n=22$ lizards, 40 bouts: Anderson 1986). Also reproductive lizards were abroad longer, thus could forage longer. 
TABLE 5. Composite energy budgets of free-living Cnemidophorus tigris during the reproductive season. Terms of energy budget are: $R=$ respiration $(R=$ FMR, measured by doubly labeled water), $P=$ production, and $M=$ metabolizable energy consumed.

\begin{tabular}{ccccccccc}
\hline \hline & \multirow{2}{*}{$\begin{array}{c}\text { Body } \\
\text { mass }\end{array}$} & Year of & \multicolumn{5}{c}{ Energy flow $(\mathrm{J} / \mathrm{d})$} \\
\cline { 4 - 8 } & $(\mathrm{g})$ & estimate & $R$ & + & $P$ & $=$ & $M$ \\
\hline Large & 21 & $1979-1982$ & 6258 & + & 0 & $=$ & 6258 \\
male & & 1983 & 6258 & + & $130 \ddagger$ & $=$ & 6388 \\
Small & 16 & $1979-1982$ & 4768 & + & $225 \ddagger$ & $=$ & 4993 \\
male & & 1983 & 4768 & + & $544 \ddagger$ & $=$ & 5312 \\
Female & 16 & 1980 & 3952 & + & $1088 \dagger$ & $=$ & $5040^{*}$ \\
& & $1981-1983$ & 3952 & + & $1238 \ddagger$ & $=$ & 5190
\end{tabular}

* $M$ calculated from water influx data.

$+P$ calculated by subtraction $(P=M-R)$.

$\ddagger P$ was calculated based on rate of mass increase and energy content of the added tissue. (See Discussion: Energy Budgets: Production Energy.)

The facts that (1) large males in the postreproductive season maintained mass, (2) larger males during the reproductive season maintained relatively constant mass even though they were active longer each day and appeared to spend effort in search of females to court, and (3) food energy acquired during the reproductive season permitted females to lay eggs (and the smaller of the 1st-yr males to grow), all indicate higher energy use in the reproductive season.

Hence, we think $C$. tigris individuals stay out longer each day during the reproductive season because of (1) time spent on behaviors associated with reproduction and (2) high energy requirements for production as growth and reproduction (Karasov and Anderson 1984). Accordingly, we considered the difference between FMR during the reproductive and postreproductive seasons to be the metabolic cost of reproduction: $88 \mathrm{~J} \cdot \mathrm{g}^{-1} \cdot \mathrm{d}^{-1}$ for males (equals 298 minus 210) and 37 for females (equals 247 minus 210). We will subsequently use this difference value in our estimate of reproductive effort (RE) of C. tigris.

Production energy. - We calculated production energy during the reproductive season for three classes of $C$. tigris: (1) females, for which production energy $(P)$ is principally a function of energy deposited into eggs, (2) 1st-yr males, for which $P$ is a function of energy deposited into new body tissue, and (3) older males that experienced little change in body mass during the breeding season $(P \approx 0)$. Because the smaller of the 1 st-yr females laid eggs and did not show net positive increase in length or mass during the 1979-1982 breeding seasons, we grouped them with larger 1st-yr and older females and constructed a budget for an "average" female of $16 \mathrm{~g}, 85 \mathrm{~mm}$ SVL.

Production rates (Table 5) were calculated by multiplying rate of mass increase and the energy content of lizard tissue. We assumed mass gains were proportionally $74 \%$ body water and $26 \%$ dry matter, based on our measurements of body water content during the reproductive season (see Methods: Rates of Field Metabolism and Water Influx). We also assumed that mass increase in young males was due to growth (i.e., they increased in body length), not deposition of fat (posterior-abdominal fat pads were $<0.1 \mathrm{~g}$ wet mass; $\mathrm{R}$. A. Anderson, personal observation). Dry mass changes of Cnemidophorus were converted to stored energy changes using 19.2 J/mg dry tissue (from Vitt 1978, but with his ash corrections recorrected by us, so ours are not ash-free values) and $26.6 \mathrm{~J} / \mathrm{mg}$ dry egg (i.e., dry yolk) (again from Vitt 1978, with his ash corrections recorrected by us), or $11.4 \mathrm{~kJ} / \mathrm{egg}$ (from Vitt 1978, for similar-sized $C$. tigris). Thus, production equalled mass increase (in grams per day) $\times 4.99 \mathrm{~kJ} / \mathrm{g}$ wet mass for males, and grams per day $\times 6.92 \mathrm{~kJ} / \mathrm{g}$ wet mass for females.

The energy equivalent for mass gain of female tissue may be an underestimate because this tissue is probably follicular ( $\approx 41 \%$ fat, $59 \%$ protein) and not whole lizard tissue. Follicles may have lower water content than whole lizard tissue, which has less fat (fat is deposited with less water than is protein).

For the springs of 1979-1982 small males gained mass at an average rate of $45 \mathrm{mg} / \mathrm{d}$, so $P=225 \mathrm{~J} / \mathrm{d}$ (Table 5). Growth rates were more than twice as high in small males in $1983(P=544 \mathrm{~J} / \mathrm{d})$. In 1983 the larger males grew too, at a rate of $26 \mathrm{mg} / \mathrm{d}$; so $P=130 \mathrm{~J} / \mathrm{d}$.

Females depositing matter into eggs gained mass at a rate of $179 \mathrm{mg} / \mathrm{d}$ in $1981-1983$, so $P=1238 \mathrm{~J} / \mathrm{d}$. Production $(P)$ for females was probably underestimated for 1981-1983 because we may have underestimated the energy equivalent of the mass gain. For $1980, P$ calculated as the difference between food intake from water influx data and FMR was $68 \pm 18$ $\mathrm{J} \cdot \mathrm{g}^{-1} \cdot \mathrm{d}^{-1}(n=7$ females for whom both FMR and water turnover were determined, mean mass $16.5 \mathrm{~g}$ ), or $1088 \mathrm{~J} / \mathrm{d}$ for a hypothetical $16-\mathrm{g}$ female. We subsequently used these production rates in our estimates of reproductive effort.

Both the production rate based on rate of mass increase in females and that based on water turnover data account for the energy deposited in a clutch of eggs during $25 \mathrm{~d}$. Based on the body size : clutch size relationship (Fig. 3), on average, a 16-g female would have a first clutch of 2.6 eggs and a second clutch of 2.0 eggs. Body mass changes of females and behavioral data indicate females require $\approx 25 \mathrm{~d}$ to produce each clutch. Based on rates of mass increase of reproductive females between clutches during 1981 and 1982, production energy accounts for $61.9 \mathrm{~kJ}$ ( 2 clutches $\times 25$ $\mathrm{d} /$ clutch $\times 1238 \mathrm{~J} / \mathrm{d}$ ), or $118 \%$, of the energy in two clutches (4.6 eggs in two clutches $\times 11.4 \mathrm{~kJ} / \mathrm{egg}=52.4$ $\mathrm{kJ})$. Using $P$ estimates from labeled lizards in 1980 , production energy can account for $61.2 \mathrm{~kJ}(50 \mathrm{~d} \times$ $1088 \mathrm{~J} / \mathrm{d}$ ), or $104 \%$ of the energy in two clutches.

Production rates of female Cnemidophorus tigris during the reproductive season in the Chuckwalla Valley appear to account for all the energy in their clutches. 
For comparison, up to $25 \%$ of the energy in one clutch of Uta stansburiana was derived from fat stores rather than from recently collected food (Nagy 1983). Furthermore, in studies of $C$. tigris elsewhere, estimates of the contribution of stored energy left over from hibernation to the energy in a single clutch are $10 \%$ (Vitt and Ohmart 1977) and 39\% (Gaffney and Fitzpatrick 1973). In instances such as these, energy budgets of reproductive reptiles must include the stored energy used for reproduction (Congdon et al. 1982a). In our study this is obviated, in part, because the two independent production-rate estimates fully account for the energy in the eggs. The labeled-water study, however, was performed after the first clutch had already been laid, and fat bodies were small. Some lipid reserves may have been mobilized for the first clutch.

\section{Comparison of frequency of egg laying and rates of production between wide-foraging and ambush lizards}

Clutch mass, size, and frequency of egg laying. Lizards with different predation modes generally have different body forms, which may affect reproduction (Vitt and Congdon 1978, Huey and Pianka 1981, Vitt and Price 1982). Wide-foraging Cnemidophorus generally have elongate bodies whereas terrestrial ambushing iguanids have a stouter body form (L. Vitt and J. Peterson, personal communication). For example, at $70 \mathrm{~mm}$ SVL, Sceloporus undulatus (Iguanidae) weighs $12.4 \mathrm{~g}$ (Tinkle and Ballinger 1972), C. tigris (Teiidae) weighs $8.5 \mathrm{~g}$ (mass determined by linear regression, $n=70, r^{2}=0.98, \ln$ mass $\left.=3.299, \ln \mathrm{SVL}=11.873\right)$, and $C$. sexlineatus weighs $7.1 \mathrm{~g}$ (Fitch 1958 and our regression in Appendix II, from his data).

Clutch masses relative to body mass (i.e., relative clutch mass, RCM) are lower in lizards with elongate bodies than in lizards with stout bodies (Vitt and Congdon 1978). A consequence of these relationships is that wide-foraging lizards have either smaller eggs or fewer eggs than ambushers of similar body mass. Indeed, Vitt (1977) presented data from which we can derive the information that wide-foraging teiids have fewer, and larger, eggs per clutch than ambush iguanids of similar body mass. However, a careful comparison of egg size and energy per egg in the two groups has not been performed (but see Rates of Reproductive Production, below).

Maximum clutch size must be related to maximum clutch mass and optimum egg size (discussed below; Rates of Reproductive Production), hence there may be a relationship of clutch size to food-acquisition mode as well. But frequency of oviposition (the interval between successive clutches), as well as clutch size, determines the number of eggs produced per unit time and per reproductive season. To compare the number of eggs produced per unit time by lizards that differ in food-acquisition mode (and phylogeny), we have summarized estimates of clutch size and clutch intervals (time to form and oviposit one clutch) for eight species (or subspecies) of Cnemidophorus and 13 species of iguanids (Table 6).

Because data sets of this kind are scarce, we have included first clutches, recognizing that the intervals (from the end of hibernation to the first clutch) over which clutches were produced may be over- or underestimated because: (1) the precise end of hibernation may be earlier or later than estimated and (2) daily activity early in the activity season immediately following hibernation is often intermittent due to variable weather conditions. Furthermore, as we discuss subsequently, fat left over from hibernation may affect clutch size, or the time to form a clutch, or whether a clutch is formed at all.

Clutch size (Table 6) was not significantly related to body mass in 10 measurements among eight populations of Cnemidophorus. These Cnemidophorus had significantly smaller clutches than the iguanids (28 populations among 22 species, in 6 genera) as a group (i.e., lower intercept, $F_{1,27}=8.435, P<.01$, and similar slope, $\left.F_{1,26}=0.635, P>.05\right)$. Comparing two genera, Cnemidophorus (mean body mass $\pm \mathrm{SD}=10.5 \pm 6 \mathrm{~g}$, $n=6$ species) and Sceloporus (mean body mass $\pm \mathrm{SD}=$ $16.7 \pm 16 \mathrm{~g}, n=7)$, mean ( $\pm \mathrm{SD})$ clutch size of Cnemidophorus, at $3.3 \pm 0.77$ eggs is significantly smaller ( $t$ test, $P<.01$ ) than that of Sceloporus, at $8.7 \pm 3.9$ eggs. Body size and the estimated clutch interval were apparently unrelated, but clutch interval was significantly shorter in Cnemidophorus than in iguanids $(30 \pm 1 \mathrm{~d}, n=9$ vs. $48 \pm 1 \mathrm{~d}, n=28 ; t$ test, $P<$ $.001)$. Clutch interval $(\bar{X} \pm \mathrm{SD})$ was significantly shorter in Cnemidophorus than in Sceloporus also (30.4 \pm 2.5 d vs. $53.1 \pm 9.3 \mathrm{~d}$; $t$ test, $P<.001)$.

The time (hypothetical) to produce a single egg (derived from the time to form and lay a clutch divided by clutch size) in Cnemidophorus is not significantly different from (though a little shorter than) either the ambush iguanids in general $(9 \pm 1 \mathrm{~d}, n=9$ vs. $12 \pm$ $1, n=28$; $t$ test, $P>.2$; Table 6 ) or Sceloporus in particular (Cnemidophorus: $\bar{X} \pm \mathrm{SD}=9.6 \pm 2.1 \mathrm{~d}, n=$ 6; Sceloporus: $\bar{X} \pm \mathrm{SD}=13.0 \pm 3.6 \mathrm{~d}, n=7 ; t$ test, $P>.2)$. The validity of this time per egg comparison is supported when one examines Anolis, the arboreal, ambush iguanids of the Caribbean. These lizards require $\approx 10-12 \mathrm{~d}$, and sometimes as little as $8 \mathrm{~d}$ to form and oviposit their single-egg clutches (Andrews 1979).

Close inspection of Table 6 reveals that two arboreal iguanids, Urosaurus ornatus and Sceloporus olivaceous, both of which produce unusually small eggs relative to adult body mass, can apparently produce a single egg faster than other lizards of either predation mode, most of which are primarily terrestrial. However, in general, there is a direct relationship between clutch size and time to produce the clutch among iguanid lizards. Moreover, the number of eggs produced per unit time (the inverse of time per egg) is similar in Cnemidophorus and iguanids. Perhaps Cnemidophorus with their 
TABLE 6. Some reproductive parameters of arthropodivores: wide-foraging Cnemidophorus and ambush iguanids. SVL $=$ snout-vent length, $\mathrm{C} 1=1$ st clutch, $\mathrm{C} 2=2$ nd clutch.

\begin{tabular}{|c|c|c|c|c|c|c|c|c|}
\hline \multirow[b]{2}{*}{ Species } & \multirow[b]{2}{*}{ Location } & \multirow[b]{2}{*}{$\begin{array}{l}\text { SVL } \\
(\mathrm{mm})\end{array}$} & \multirow[b]{2}{*}{$\begin{array}{l}\text { Body } \\
\text { mass } \\
(\mathrm{g})\end{array}$} & \multirow[b]{2}{*}{$\begin{array}{l}\text { Clutch } \\
\text { energy* } \\
(\mathrm{kJ})\end{array}$} & \multirow[b]{2}{*}{$\begin{array}{l}\text { Clutch } \\
\text { size } \\
\text { (no. eggs) }\end{array}$} & \multicolumn{2}{|c|}{ Time for: } & \multirow[b]{2}{*}{$\begin{array}{l}\text { Refer- } \\
\text { ence§ }\end{array}$} \\
\hline & & & & & & $\begin{array}{l}\text { entire } \\
\text { clutch } \\
\text { (d) }\end{array}$ & $\begin{array}{l}\text { single } \\
\text { egg } \\
\text { (d) }\end{array}$ & \\
\hline \multicolumn{9}{|l|}{ Wide foragers } \\
\hline 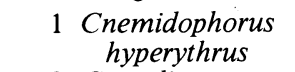 & San Diego Co., California & 60 & 4.5 & 11.8 & 2.3 & 30 & 13.0 & 7 \\
\hline 2 C. sexlineatus & Lubbock Co., Texas & 65 & 5.8 & 42.1 & 3.8 & 35 & 9.2 & 15,11 \\
\hline 3 C. uniparens & Cochise Co., Arizona & 66 & 7.3 & 19.4 & $\mathrm{C} 22.8$ & 30 & 10.7 & 16 \\
\hline 4 C. inornatus & Four Peaks Mts., Arizona & 71 & 9.9 & 17.5 & 3.3 & 30 & 9.1 & 25 \\
\hline 5 C. gularis & Tom Green Co., Texas & 80 & 15 & 28.1 & 4.5 & 30 & 6.7 & 4 \\
\hline $\begin{array}{l}6 \text { C. tigris } \\
\text { septentrionalis }\end{array}$ & Colorado & 82 & 17 & 38.9 & 3.4 & 30 & 8.8 & 20 \\
\hline 7 C. tigris tigris & $\begin{array}{l}\text { Colorado Desert, } \\
\text { California }\end{array}$ & 85 & 16 & $\begin{array}{l}42.2 \\
29.6 \\
23.9\end{array}$ & $\begin{array}{ll}\text { C1 } & 3.7 \\
\text { C1 } & 2.6 \\
\text { C2 } & 2.1\end{array}$ & $\begin{array}{l}25 \\
25 \\
25\end{array}$ & $\begin{array}{r}6.8 \\
9.6 \\
11.9\end{array}$ & $\begin{array}{l}29 \\
28\end{array}$ \\
\hline $\begin{array}{l}8 \text { C. tigris } \\
\quad \text { multisculatus }\end{array}$ & $\begin{array}{l}\text { San Gabriel Mts., } \\
\text { California }\end{array}$ & 101 & 28 & 62.0 & 4.1 & 31 & 7.6 & 14 \\
\hline \multicolumn{9}{|l|}{ Ambushers } \\
\hline \multirow{5}{*}{$\begin{array}{c}9 \text { Urosaurus } \\
\text { ornatus }\end{array}$} & Brewster Co., Texas & 48 & 2.4 & 8.5 & 4.7 & 46 & 9.8 & 9,10 \\
\hline & Chiricahua Mts., Arizona & 49 & 2.5 & $\begin{array}{l}17.1 \\
10.1\end{array}$ & $\begin{array}{ll}\text { C1 } & 9.0 \\
\text { C2 } & 5.3\end{array}$ & $\begin{array}{l}40 \ddagger \\
33\end{array}$ & $\begin{array}{l}4.4 \\
6.2\end{array}$ & 24,10 \\
\hline & Sunflower, Arizona & 51 & 2.6 & 13.0 & 7.2 & 40 & 5.6 & 31,10 \\
\hline & Hidalgo Co., New Mexico & 50 & 2.6 & $\begin{array}{l}16.4 \\
11.3\end{array}$ & $\begin{array}{lr}\text { C1 } & 10.9 \\
\text { C2 } & 7.5\end{array}$ & $\begin{array}{l}47 \\
35\end{array}$ & $\begin{array}{l}4.3 \\
4.7\end{array}$ & $\begin{array}{l}1,2 \\
21,10\end{array}$ \\
\hline & $\begin{array}{l}\text { Maricopa Co., Arizona } \\
\text { Maricopa Co., Arizona }\end{array}$ & $\begin{array}{l}51 \\
55\end{array}$ & $\begin{array}{l}4.0 \\
4.7\end{array}$ & $\begin{array}{l}15.4 \\
16.7\end{array}$ & $\begin{array}{l}7.1 \\
7.7\end{array}$ & $\begin{array}{l}39 \\
43\end{array}$ & $\begin{array}{l}5.5 \\
5.6\end{array}$ & $\begin{array}{l}31 \\
33\end{array}$ \\
\hline \multirow[t]{4}{*}{$\begin{array}{l}10 \text { Uta stansburi- } \\
\text { ana }\end{array}$} & Rock Valley, Nevada $†$ & 46 & 3.5 & $\begin{array}{l}8.3 \\
7.9\end{array}$ & $\begin{array}{ll}\text { C1 } & 3.1 \\
\text { C2 } & 3.0\end{array}$ & $\begin{array}{l}60 \\
57\end{array}$ & $\begin{array}{l}19.4 \\
19.0\end{array}$ & 22 \\
\hline & Rock Valley, Nevada $†$ & 46 & 3.5 & $\begin{array}{l}12.0 \\
12.0\end{array}$ & $\begin{array}{l}\text { C1 } 4.5 \\
\text { C2 } 4.5\end{array}$ & $\begin{array}{l}47 \\
27\end{array}$ & $\begin{array}{r}10.4 \\
6.0\end{array}$ & 32 \\
\hline & Winkler Co., Texas & 46 & 3.3 & 10.4 & 3.9 & 65 & 16.7 & 30 \\
\hline & $\begin{array}{l}\text { San Gabriel Mts., } \\
\text { California }\end{array}$ & 48 & 3.8 & 9.4 & 3.5 & 65 & 18.6 & 14 \\
\hline $\begin{array}{l}11 \text { Sceloporus } \\
\text { merriami }\end{array}$ & Brewster Co., Texas & 53 & 4.0 & $\begin{array}{l}12.1 \\
12.1\end{array}$ & $\begin{array}{ll}\text { C1 } & 4.9 \\
\text { C2 } 4.9\end{array}$ & $\begin{array}{l}53 \\
64\end{array}$ & $\begin{array}{l}10.8 \\
13.1\end{array}$ & 9 \\
\hline 12 S. graciosus & Kolab Mesa, Utah & 61 & 5.0 & $\begin{array}{l}13.3 \\
13.3\end{array}$ & $\begin{array}{ll}\text { C1 } & 4.0 \\
\text { C2 } & 4.0\end{array}$ & $\begin{array}{l}50 \\
50\end{array}$ & $\begin{array}{l}12.5 \\
12.5\end{array}$ & 8 \\
\hline $13 S$. virgatus & Chiricahua Mts., Arizona & 60 & 5.6 & 28.3 & 9.3 & $60 \ddagger$ & 6.5 & 24 \\
\hline $14 S$. scalaris & Chiricahua Mts., Arizona $\dagger$ & 56 & 6.5 & 21.6 & 10.0 & $60 \neq$ & 6.0 & 3,23 \\
\hline \multirow[t]{2}{*}{17 S. occidentalis } & $\begin{array}{l}\text { Los Angeles Co., } \\
\text { California† }\end{array}$ & 65 & 10.4 & 28 & 7.0 & 50 & 7.1 & 12,34 \\
\hline & Nye Co., Nevada & 81 & 21.0 & 68.3 & 11.5 & 60 & 5.2 & 26 \\
\hline 20 S. olivaceous & Austin, Texas & 97 & 35 & 61.05 & 15.8 & 34 & 2.2 & 6 \\
\hline 21 S. magister & Nye Co., Nevada & 95 & 45 & 54.2 & 7.6 & 53 & 7.6 & 27 \\
\hline $\begin{array}{l}15 \text { Cophosaurus } \\
\text { texanus }\end{array}$ & Tom Green Co., Texas & 60 & 6.3 & 30.2 & 6.1 & 37 & 6.1 & 5 \\
\hline $\begin{array}{l}16 \text { Callisaurus } \\
\text { draconoides }\end{array}$ & Colorado Desert, California & 70 & 9.3 & 25.7 & $\mathrm{C} 14.4$ & 50 & 11.4 & 17 \\
\hline 18 Uma notata & Imperial Co., California & 76 & $\approx 20$ & & 2.1 & 45 & 21.4 & 18 \\
\hline 19 U. scoparia & $\begin{array}{l}\text { San Bernardino Co., } \\
\text { California }\end{array}$ & 83 & $\approx 20$ & & 2.6 & 43 & 16.5 & 19 \\
\hline
\end{tabular}

* Clutch energy was calculated as the product of the clutch size and the energy content per egg (from Appendix Table A1). Some of the values in this table are estimated by us. Our estimates are based on anecdotes of authors, interpolations, and extrapolations of their data sets, and by referring to data sets of related species.

$\dagger$ Indicates data for 2-yr-old females.

Indicates that the time for egg retention was subtracted in order to estimate the time for production of the entire clutch.

$\$ 1$, Ballinger 1976; 2, Ballinger 1977; 3, Ballinger and Congdon 1981; 4, Ballinger and Schrank 1972; 5, Ballinger et al. 1972; 6, Blair 1960; 7, Bostic 1966; 8, Congdon and Tinkle 1982; 9, Dunham 1981; 10, Dunham 1982; 11, Fitch 1958; 12, Goldberg 1973; 13, Goldberg 1976; 14, Goldberg 1977; 15, Hoddenbach 1966; 16, Hulse 1981; 17, W. H. Karasov and R. A. Anderson, personal observation; 18, Mayhew 1966a; 19, Mayhew 1966b; 20, McCoy 1965; 21, Michel 1976; 22, Nagy 1983; 23, Newlin 1976; 24, Smith 1981; 25, Stevens 1983; 26, Tanner and Hopkin 1972; 27, Tanner and Krogh $1973 b$; 28 , this study, 1979-1982; 29, this study, 1983; 30, Tinkle 1961; 31, Tinkle and Dunham 1983; 32, Turner et al. 1970; 33, Van Loben Sels and Vitt 1984, and Vitt 1977. 
smaller relative clutch masses have the advantage, like Anolis (Stamps and Tanaka 1981), of responding to favorable changes in food, thermal, and moisture conditions more rapidly than most iguanids. But wide foragers may be constrained to smaller clutch mass due to effects of the clutch mass load on the cost of transport or ability to escape predators in the open (Shine 1980, Vitt and Price 1982). Certainly, a perennial question is raised here, "What are the costs and benefits of laying few eggs frequently vs. laying many eggs less often?"

We interpret the data summarized in Table 6 to mean that the wide-foraging mode of predation may not be associated with a lower reproductive output than the ambush mode, as might be deduced from the comparison of relative clutch masses in teiids and iguanids. Given that (1) an elongate body form in lizards, which is associated with the predation mode of wide foraging, greatly constrains the maximum volume or mass of the clutch in these wide foragers (Vitt and Congdon 1978), and (2) the apparent "optimal" egg size for these wide foragers dictates fewer, larger eggs per clutch mass than in iguanids (Cuellar 1984, below), then teiids have smaller clutch size. But teiids may produce more clutches per unit time (based on the time required to form a clutch). Thus, even with their smaller clutch masses and larger eggs some individual teiids may equal most individual iguanids in the number of eggs laid per equal-length reproductive season, in desert environments. Hence, individual reproductive success, as measured by the number of offspring produced per reproductive season, may be similar among lizards with different food-acquisition modes, despite unequal clutch sizes.

This hypothesis may be correct only if daily food intake is neither to satiation nor to maximum filling of stomach. For some populations of Urosaurus ornatus and $S$. undulatus (S. Jones, personal communication), and perhaps Sceloporus olivaceous (Blair 1960), energy intake and production may be near the maximum because food may be effectively superabundant. The body morphology and larger relative clutch mass of these iguanids in this situation, particularly in $U$. ornatus and $S$. olivaceous with their unusually small eggs, permits production of more eggs per given length of reproductive season than for Cnemidophorus. But most other habitats, particularly in deserts, surely have lower food availability, so that net rate of energy intake in most ambushers will generally be lower and the analytical results for desert lizards of Table 6 may be more typical.

We suspect that careful analysis of the reproductive state of individual females from syntopic populations of wide foragers and ambushers in midlatitude deserts would reveal that individuals of these different types of predators often produce similar numbers of eggs during the spring-summer reproductive seasons, especially in years or habitats in which prey availability is comparatively low. For example, the unusually warm dry winter-spring of 1984, with low food availability (R. A. Anderson, personal observation), was a poor reproductive season for lizards in the Chuckwalla Valley. Most female $C$. tigris laid two small clutches $(2.0$ eggs/clutch) by early May, whereas only a small proportion of adult female $C$. draconoides were reproductively active ( 3.0 eggs/single clutch in mid-to-late May), and most had atretic or tiny unyolked follicles (R. A. Anderson, personal observation).

In some neotropical habitats Cnemidophorus and other macroteiids may reproduce year-round (depending on the severity and length of the dry season) whereas iguanids tend to have more restricted reproductive seasons (Vitt 1982). Even if iguanids reproduced repetitively (and continuously), we suggest that teiids of the same body mass may produce more clutches and perhaps more eggs (given that egg sizes are not too dissimilar) in the same time span.

Rates of reproductive production. - If the number of eggs formed and laid per unit time is similar among most wide-foraging Cnemidophorus and ambush iguanids (comparisons among predominant arthropodivores only), then the rates of production (i.e., rate of energy deposition into eggs) may be similar between the two groups, given that the energy per egg is similar.

Our analysis of egg size and egg energy in Cnemidophorus and iguanids (Appendix I; Fig. 6A) reveals that energy per egg relative to female body mass is not the same in the two groups. Eggs of Cnemidophorus species weigh, on average, $55 \%$ more than eggs of iguanids of similar body mass $(P<.005$; ANCOVA of natural $\log$ wet mass per egg vs. natural log female body mass in the two groups). Furthermore, eggs of Cnemidophorus species contain more dry matter $(55.7 \%$ of wet mass) than do eggs of iguanids (46.5\% of wet mass: Congdon et al. 1978, Vitt 1978), so the difference in dry mass per egg is even greater. Because there is no significant difference in the energy content per unit mass of dry egg between Cnemidophorus and iguanids (Vitt 1978, Congdon et al. 1982a), the total energy content of Cnemidophorus eggs also exceeds that of iguanid eggs, by an average of $87 \%$ (intercept test, $F_{1,32}=$ 59.3, $P<.005$; Fig. 6A).

If Cnemidophorus produced eggs at least $50 \%$ smaller (i.e., similar to iguanids), they could add one egg for every two they form, yielding a putative $50 \%$ increase in egg production. This apparent greater "parental investment" within Cnemidophorus at the cost of a lower number of young is intriguing. It seems reasonable that stout-bodied iguanids with unusually small eggs even for iguanids (e.g., Sceloporus olivaceous) would produce more eggs per reproductive season that Cnemidophorus under most situations. A comparison of mortality schedules among Sceloporus with different relative egg sizes and between Cnemidophorus and these Sceloporus would be useful. Congdon et al. (1978), Smith and Fretwell (1974), Ferguson et al. (1982), Nussbaum (1981), and Rand (1982) discuss the compromise be- 

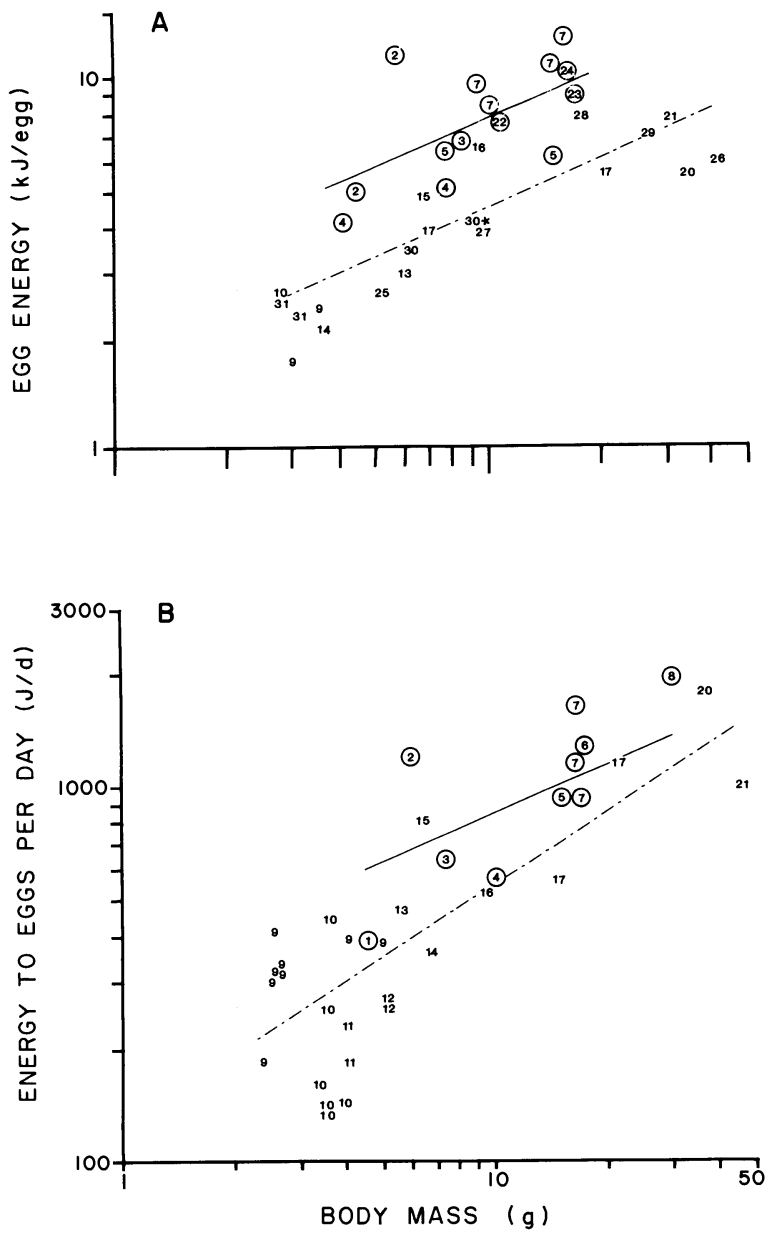

Fig. 6. Relationships between body size and several reproductive parameters in Cnemidophorus ( - ) and iguanids $(-.--)$. The numbers are the species identification (ID) numbers in Table 6 and Appendix II; circled numbers are Cnemidophorus species. (A) shows the energy content per egg as a function of body mass. There is a significant correlation between $\ln$ (body mass) and $\ln$ (energy/egg) $\left(F_{1,32}=73.2, P<\right.$ $.005)$. There is no significant difference in slope between Cnemidophorus and iguanids $\left(F_{1,31}=0.004, P>.05\right.$; common slope $=0.45$ ), but the intercept for Cnemidophorus is significantly greater than for the iguanids $\left(2.81\right.$ vs. $1.50, F_{1,32}=$ $59.3, P<.005$ ). (B) shows the apparent rate of energy deposition into eggs (calculated as clutch energy divided by time for a clutch) as a function of body mass in the two groups. There is a significant correlation between $\ln$ (body mass) and $\ln$ (energy/d into eggs) $\left(F_{1,33}=44.8, P<.005\right)$. There is no significant difference in slope between Cnemidophorus and iguanids $\left(F_{1,32}=1.30, P>.25\right.$, common slope $\left.=0.59\right)$, but the intercept for Cnemidophorus is significantly greater than for the iguanids $\left(214\right.$ vs. $\left.136, F_{1,33}=6.78, P<.025\right)$. These figures indicate that Cnemidophorus have higher apparent rates of energy deposition into eggs primarily because Cnemidophorus eggs have greater dry mass and contain more energy. tween number and size of young in lizards. In iguanids and Cnemidophorus, wet mass of individual eggs varies with female body mass and varies inversely with clutch size (Nussbaum 1981, Ferguson et al. 1982, Rand 1982, Cuellar 1984). Subsequently, we will consider the implications of the difference between Cnemidophorus and iguanids in mass per egg and energy per egg with respect to hatchling size.

Recall that the time per egg, and hence number of eggs per unit time, is similar among wide-foraging Cnemidophorus and ambush iguanids. Thus, if one were to approximate the rate of production as the product of number of eggs per unit time and the energy content per egg, then Cnemidophorus would have higher production rates (Fig. 6B). For terrestrial iguanids (excluding Urosaurus) and Cnemidophorus, egg energy per day increases with female body mass, and Cnemidophorus exceed iguanids of similar body mass by $65 \%$, on average $(P<.01$; ANCOVA of $\ln$ [egg energy per day] vs. $\ln$ [female body mass] in the two groups). When the arboreal Urosaurus are included, Cnemidophorus still exceed the iguanids in the rate of energy deposition into eggs, by $58 \%$ on average (intercept test, $F_{1,33}=$ 6.78, $P<.025$; ANCOVA; Fig. 6B). No significant difference exists between the two groups in the slope of the relationship between $\ln$ of the rate of energy deposition into eggs and $\ln$ body mass $\left(F_{1,32}=1.30\right.$, $P>.25$; Fig. 6B).

Note that the product of number of eggs per unit time and the energy content per egg could overestimate the rate of reproductive production, depending on how much of the fat stored the previous autumn was unused in hibernation and was subsequently used for production of the first clutch (little fat is available in subsequent clutch intervals: Nagy 1983). Because some of the energy in the first clutch may have been gathered the preceding fall, the time interval between end of hibernation and the first clutch may be the improper time interval for calculating production. In the aforementioned examples of $C$. tigris and Uta this overestimate ranged from 0 to $40 \%$.

No major apparent differences exist between Cnemidophorus and iguanids in the amount of fat left over from hibernation that is used in reproduction, although the data are few. Decrease in size of fat bodies coincident with yolk deposition (Hahn and Tinkle 1965) has been noted in virtually every genus of lizard in the western United States, though fat-body utilization may vary with environmental resources (Ballinger 1977) and may not reflect the lipid input from the rest of the body to eggs (Derickson 1976a,b). Considering that these unknowns apply to all the species in our comparison, and also considering the large difference between Cnemidophorus and the six genera of iguanids in the parameter we have called "energy to eggs per day," we think Fig. $6 \mathrm{~B}$ is a qualitatively accurate representation of reproductive energetics in these lizards.

This apparent difference in the rate of reproductive 
production is in concordance with our prediction that because wide foragers have higher rates of net energy intake while foraging they may also have higher instantaneous rates of production (see also Andrews 1984).

Rates of growth. - We suggest further that higher rates of net energy intake in the wide-foraging arthropodivores, such as Cnemidophorus, potentially result in higher rates of growth per day during the growing season than in syntopic ambush iguanids (which also prey mostly upon arthropods) of similar body mass and age. Limited data are available to test this prediction, and most of it is measurements of SVL, rather than mass. In our review of the literature of lizards indigenous to western North America Cnemidophorus (Fitch 1958, Smith 1974, Hulse 1981) had significantly higher growth rates (in SVL) than iguanids (Tanner and Krogh 1973a, Dunham 1978, Ferguson and Brockman 1980, Tinkle and Dunham 1983) of similar body length $(30-45 \mathrm{~mm})$ and growth stage $(25-75 \%$ of adult size) $(0.56 \pm 0.05$ $\mathrm{mm} / \mathrm{d}[n=4]$ vs. $0.25 \pm 0.05[n=5] ; P<.005$; twotailed $t$ test). Although the mass-to-length ratio of many iguanids is higher than that of the slimmer Cnemidophorus the mass-length differences may not be great enough (L. Vitt and J. Peterson, personal communication) to obscure this trend. Below, we calculate an indirect measure of growth rate and also find that Cnemidophorus grow faster than similar-sized iguanids. Higher growth rates in wide foragers are further suggested by greater rates of mass increase in the wide forager Eremias lugubris of the Kalahari Desert, compared with the syntopic "ambusher" Eremias lineocellata (Nagy et al. 1984)

Higher growth rates (in SVL and mass) of juvenile wide foragers, compared with syntopic ambushers, may have two important consequences for reproduction. First, at first reproduction, wide-foraging Cnemidophorus may be larger than ambush iguanids of equivalent age. Second, at equivalent size at first reproduction Cnemidophorus may tend to be younger. Short activity seasons in lizards of temperate zones may obscure this phenomenon. We attempted to compare ages at first reproduction in (chiefly arthropodivorous) lizards by subtracting from actual chronological age the months spent inactive in hibernation to obtain a parameter we call "activity season age." Appendix II presents the data we used to calculate this parameter.

The age at first reproduction measured as "activity season age" is positively correlated with body mass in all lizards $\left(F_{1,58}=46.4, P<.001\right.$; Fig. 7A $)$ : in iguanids $\left(P<.01, r^{2}=0.46\right)$ and in Cnemidophorus $(P<.05$, $\left.r^{2}=0.30\right)$. Although the slopes of these relationships do not differ significantly $\left(F_{1,57}=0.04, P>.05\right)$, the intercept for Cnemidophorus is only $52 \%$ that of the iguanids $\left(F_{1,58}=17.3, P<.001\right)$. Thus, Cnemidophorus reach age at first reproduction after a fewer number of months of activity. Note, actual chronological age at first reproduction will differ less markedly because
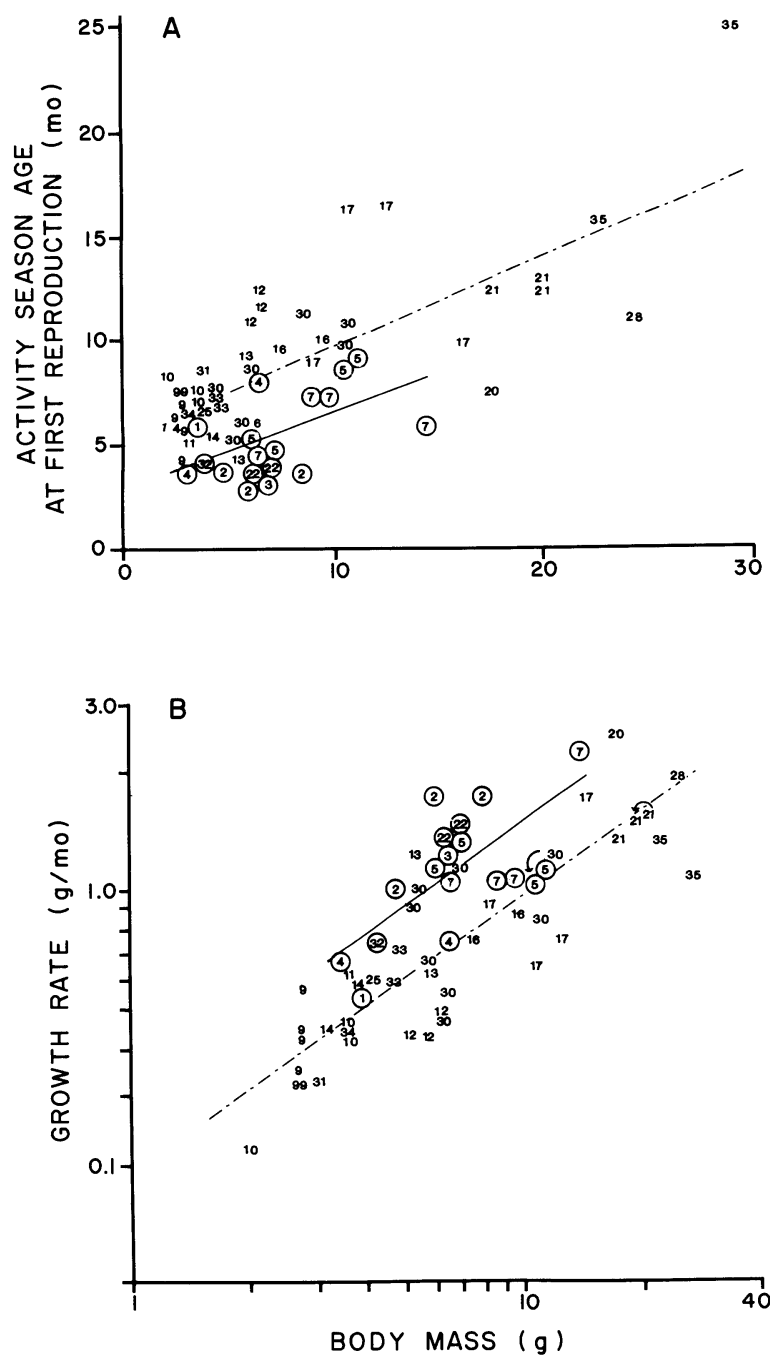

Fig. 7. Age at first reproduction and growth rate in Cnemidophorus ( - ) and iguanids (-.-.). The numbers are the species ID numbers in Table 6 and Appendix II; circled numbers are Cnemidophorus. (A) shows the age at first reproduction in "activity season months" as a function of body mass in the two groups. See Discussion: II. Comparison of Frequency of Egg Laying and Rates of Production between WideForaging and Ambush Lizards: Rates of Growth for the method of calculation of "activity season age." There is a significant correlation between body mass and age at first reproduction in the two groups $\left(F_{1,58}=46.4, P<.001\right)$. There is no significant difference in slope between Cnemidophorus and iguanids $\left(F_{1,57}=0.04, P>.05\right)$, but the intercept for Cnemidophorus is significantly lower than for the iguanids ( $2.92 \mathrm{vs}$. 5.62, $\left.F_{1,58}=17.3, P<.001\right)$. Thus, Cnemidophorus females reproduce at an earlier age. (B) shows the growth rate (calculated as [mass adult - mass hatchling]/[activity season age at first reproduction]) as a function of body mass in the two groups. There is a significant correlation between $\ln$ (body mass) and $\ln$ (growth rate) in the two groups $\left(F_{1,58}=138, P<.001\right)$. There is no significant difference in slope between Cnemidophorus and iguanids $\left(F_{1,57}=0.01\right.$, common slope $\left.=0.70\right)$, but the intercept for Cnemidophorus is significantly greater than for the iguanids $\left(0.29\right.$ vs. $\left.0.19, F_{1,58}=25.9 P<.001\right)$. Thus, Cnemidophorus achieve earlier age at first reproduction in part due to higher growth rate. 
Cnemidophorus spend $\approx 1.7$ mo longer in hibernation than do most iguanids (hibernation time for each species is listed in Appendix II; mean hibernation time: $n=$ 8 species of Cnemidophorus, $\bar{X} \pm \mathrm{SE}=5.9 \pm 0.4 \mathrm{mo}$; $n=18$ iguanids, $\bar{X} \pm \mathrm{SE}=4.2 \pm 0.4 \mathrm{mo} ; t$ test, $P<$ $.005)$.

We also calculated growth rates for lizards in these two groups by dividing the difference between hatchling mass and mass at first reproduction (excluding egg mass) by activity season age at first reproduction. Growth rate calculated in this manner was significantly correlated with body mass in both groups $\left(F_{1,58}=138\right.$, $P<.001)$. The slopes did not differ significantly $\left(F_{1,57}=\right.$ $0.01, P>0.5)$. The elevation of the Cnemidophorus regression was significantly higher than the iguanid regression however (by $52 \% ; F_{1,58}=25.9, P<.001$; Fig. 7B), a result that corroborates our previous analysis of growth rates in the two groups.

These comparisons do not take into account prey availability in the many and diverse habitats (and different years) occupied by the many lizards for which activity season age was estimated. The data sets for Cnemidophorus and the iguanids, however, represent approximately similar distributions of habitat types, latitude, altitude, and rainfall. Investigation of lizards with these different predation modes in the tropics may more readily test the hypothesis that consequences of more rapid growth in wide foragers are either larger size at first reproduction than in ambush predators of equal age, or earlier age at first reproduction in wideforaging lizards than in ambushers of equal size.

Another factor that may enable Cnemidophorus to reach reproductive age earlier or to be larger at age of first reproduction, is greater hatchling size than in iguanids. Recall that eggs are larger in larger species and that Cnemidophorus lay eggs with more mass and energy per egg than iguanids (Fig. 6A). Consequently, hatchling mass is greater in species of greater body size in iguanids and Cnemidophorus $(P<.005$, no significant difference in slope); but, Cnemidophorus hatchlings average $82 \%$ larger than hatchlings of iguanids of similar parental mass $(P<.005$ for data in Appendix II). As a percentage of adult female body mass, Cnemidophorus hatchlings average $\approx 14 \%$ (range $7.6-$ $23.5 \%$ ) vs. $8 \%$ in iguanids (range $3.6-18.6 \%$ ). The greater "parental investment" (investment into one offspring at the expense of having more offspring) within Cnemidophorus may be related to factors affecting hatchlings such as food acquisition and predation risk. For example, larger hatchlings of Cnemidophorus may be able to dig for prey more effectively and may have a longer "fasting" time before debilitation due to lack of food.

We conclude this section by considering caveats and alternative hypotheses to our hypothesis that because wide foragers have greater net energy intake, they are capable of greater reproductive production and growth production than most ambushers. Notable caveats are that the data sets for these comparisons of wide foragers and ambushers are small and imprecise. Consistent patterns among these data sets, however, support our hypothesis. Only the caveat of phylogeny (Huey and Bennett 1986) is problematical. Lizard families are statistically distinguishable in fecundity and age at maturity, for example (Dunham and Miles 1985).

Prior to discussing phylogeny, it is necessary to further elucidate what is meant by "food-acquisition mode": the apparently coordinated set of morphological, behavioral, and physiological characteristics that are integrally involved in the search, detection, capture (pursuing and subduing), and eating (ingesting, preparing, and swallowing) of food. A suite of coordinated characteristics associated with an adaptation of overriding importance, such as the acquisition of food, has been referred to as an "adaptive syndrome" (Root and Chaplin 1976, Eckhardt 1979). Widely foraging and ambushing are two such qualitatively recognizable syndromes, or modes, of food acquisition in terrestrial carnivorous lizards (Pianka 1966). We use the more inclusive phrase "food-acquisition mode" rather than foraging mode, because foraging mode, as it refers to lizards, has taken on the meaning of movement patterns only (Huey and Pianka 1981).

The food-acquisition mode of the long-bodied Cnemidophorus involves a highly mobile search, an emphasis on olfaction for detection of fossorial and hidden prey, and forelimbs and snout somewhat specialized for capturing these prey (Anderson 1988). This is a very different set of characteristics from stout-bodied, broad-mouthed iguanid predators, which are relatively sedentary, visually scan the environment, and detect and capture moving arthropod prey instead of sedentary, hidden prey. The Teiidae and Iguanidae have been recognizable since the mid-Cretaceous (Estes 1983), and may be representative of minor evolutionary "grades" or "adaptive complexes" (Mayr 1976). Phylogeny may be indicative of inherited adaptive differences in the general food-acquisition mode, rather than just a confounding factor (Fisher 1985).

Food acquisition and phylogeny are correlated with the difference in net rate of energy intake in Cnemidophorus and the iguanids, and are not cause-and-effect explanations per se. The ecological mechanisms hypothesized as the cause for difference in net energy intake must accompany these correlations. We think that the mechanistic causes for the difference in net energy intake between these predation types are principally related to their difference in mode of food acquisition, and not to some aspect of phylogeny that is not part of the food-acquisition syndrome. For example, Cnemidophorus in desert environments eat more arthropod prey per hour than syntopic ambush iguanids probably because prey, in the form of eggs, larvae, pupae, and adults of nocturnal and diurnal arthropods are available to Cnemidophorus whereas principally adults, and some larvae, of diurnal arthropods are all 
that are apparently readily available to the iguanids (Anderson 1988). So many prey are available to Cnemidophorus because of their pattern of search movement, the use of olfaction and vision to detect prey, and the digging in soil and scratching through litter; that is, because of the major components of their foodacquisition mode: search, detection, and capture. The food-acquisition mode of Cnemidophorus allows the high net energy intake of these lizards, which in turn allows them to have high rates of production. That they utilize high production is probably due to the adaptive advantage of high production associated with earlier age of reproduction (Cole 1954). The food-acquisition mode and high net rate of energy intake in Cnemidophorus do not necessarily lead to higher production than in iguanids, but it does seem to be the pattern.

A priori, other mechanistic hypotheses for these differences among the foraging Cnemidophorus and ambushing iguanids in net energy intake and production that may not be associated with food acquisition mode, but that may be in some way related to phylogenetic differences, are possible. One such hypothesis is that phylogenetic differences between Cnemidophorus and iguanids may somehow make the Cnemidophorus physiologically more "efficient" at producing new tissue from food. But at similar temperatures, there are no demonstrated differences between the two groups in digestive efficiency, time of passage of food through the gut (Harwood 1979), standard metabolic rates (Andrews and Pough 1985), or maintenance metabolism in the laboratory.

Another hypothesis is that because field-active $T_{\mathrm{b}}$ of Cnemidophorus and other teiids are higher than those of most iguanids (Brattstrom 1965), rates of various metabolic processes, such as assimilation, growth, and reproduction, will be higher in the warmer teiids. This hypothesis appears untenable for several reasons. First, the total daily sum of metabolic processes depends upon more than just $T_{\mathrm{b}}$ during the activity period. The total daily metabolism and its components are mostly a consequence of maintenance metabolism at the body temperatures experienced during the entire $24 \mathrm{~h}$ (Anderson and Karasov 1981). And, Cnemidophorus usually have shorter daily activity periods during equable weather, such that time spent underground with a cool $T_{\mathrm{b}}$ is much longer than that of syntopic iguanids (Anderson and Karasov 1981, Andrews 1984; Fig. 4, and recall excavations of sleeping $C$. tigris in the afternoon). Moreover, high $T_{\mathrm{b}}$ requirements for activity may markedly reduce daily and seasonal activity in Cnemidophorus, which inhabit temperate climates $(1.7 \mathrm{mo}$ shorter, although other factors such as greater net rate of energy intake may also allow shorter activity periods), possibly shortening time available for reproduction compared with ambush iguanids.

Within the iguanids, lizards with higher field-active $T_{\mathrm{b}}$ during activity do not tend to have higher repro- ductive or growth rates in the field (cf. Callisaurus). In fact, some iguanids can achieve higher rates of growth or deposition of energy into eggs than Cnemidophorus; such examples are Urosaurus ornatus and Sceloporus olivaceous, both of which have field-active $T_{\mathrm{b}} 3^{\circ}-5^{\circ} \mathrm{C}$ lower than Cnemidophorus and Callisaurus. We suspect that in those cases the microhabitat productivity (i.e., prey availability) is greater than for most of the other iguanids.

A comparative approach, which emphasizes the rate of production (both in terms of eggs and energy), should facilitate life history comparisons among species within the same habitat, in different habitats, and within a species in different habitats. Investigating rate of production focuses attention on the proximal mechanistic bases for differences in reproductive rates such as time available for foraging (Karasov and Anderson 1984), prey availability, frequency of prey capture, net rate of energy intake during foraging, daily $T_{\mathrm{b}}$ regime (Anderson and Karasov 1981), temperature-dependent assimilation and metabolic rates, and costs of behaviors not considered to be part of food acquisition, such as thermoregulation, predator avoidance, and social behavior.

\section{Reproductive effort in Cnemidophorus, with comparisons}

To calculate reproductive effort, RE, the total metabolizable energy flow through an animal must be estimated, along with the proportion allocated to reproduction. The "biologically meaningul time interval" in which to measure RE (Hirschfield and Tinkle 1975) may not be the same among individuals, populations, or species of lizards because so many factors affect rates of energy intake and expenditure within and between reproductive seasons. Comparisons among species in which the time interval for RE is time of clutch formation or the reproductive season will be least compromised when (1) little or no fat is used or (2) when similar proportions of reproduction energy come from fat. Because stored fat apparently contributed little to reproduction in $C$. tigris in the Chuckwalla Valley, we calculate RE of Cnemidophorus tigris over one reproductive season. We then compare it with the RE of other lizards, most of which are ambush predators.

$R E$ in C. tigris. $-\mathrm{RE}$ is expressed as the fraction of available energy flow in the lizard used for reproductive purposes (chemical potential energy in eggs and associated maintenance costs in females and maintenance costs only in males) (Nagy 1983). To calculate $\mathrm{RE}\left(\mathrm{RE}_{\mathrm{t}}=\right.$ $R_{\mathrm{r}}+P_{\mathrm{r}} /\left[R_{\mathrm{r}}+R_{\mathrm{n}}+P_{\mathrm{r}}+P_{\mathrm{g}}+P_{\mathrm{s}}\right]$ in Table 7) we used the previously determined value for production energy allocated to eggs $\left(68 \mathrm{~J} \cdot \mathrm{g}^{-1} \cdot \mathrm{d}^{-1}\right.$ in 1980 ; Table 5), metabolic costs of reproduction $\left(37 \mathrm{~J} \cdot \mathrm{g}^{-1} \cdot \mathrm{d}^{-1}\right.$ for females, 88 for males; see above, I. Energy Budgets of Cnemidophorus tigris: Activity Period Costs during Reproduction), and total metabolizable energy intake (Table 5). We normalized energy flow rates to body mass raised 
TABLE 7. Reproductive energetics $\left(\mathrm{J} \cdot \mathrm{g}^{-0.80} \cdot \mathrm{d}^{-1}\right)$ of Cnemidophorus tigris and Uta stansburiana, each producing two consecutive clutches.

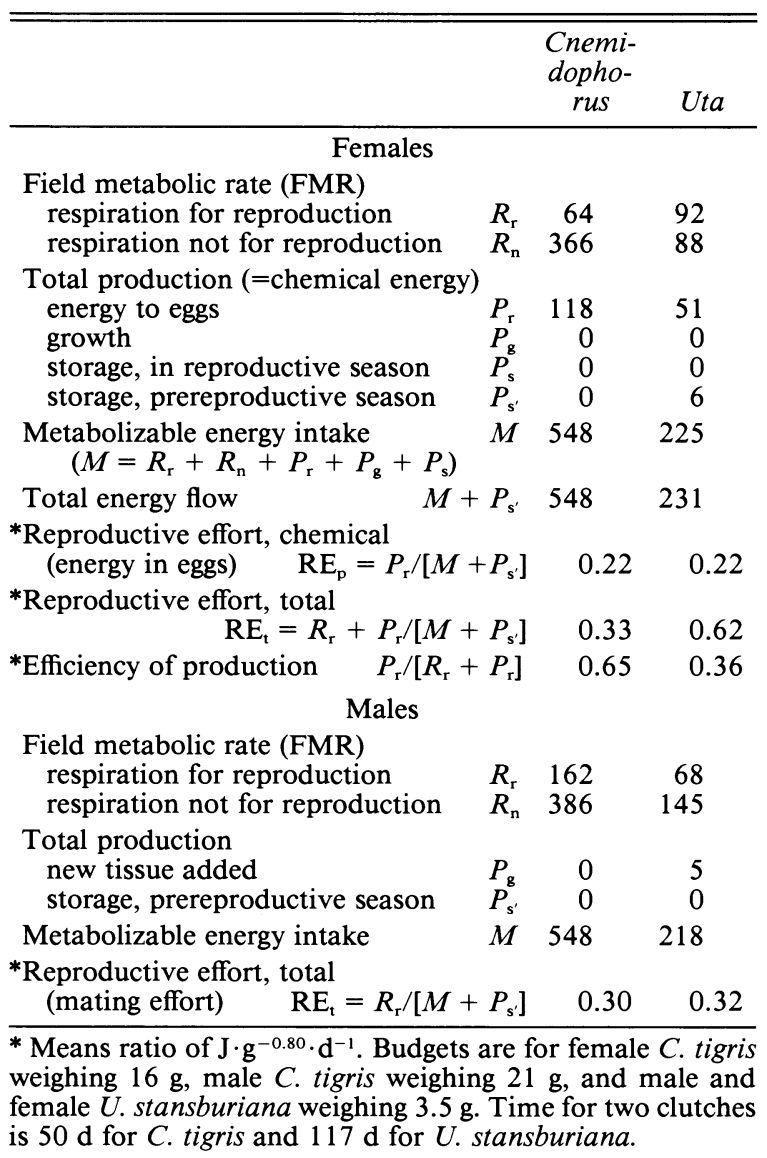

to the 0.80 power (a standard exponent for reptiles: Bennett and Dawson 1976) in order to facilitate comparison with other species of different body mass; this procedure has no effect on calculated RE values.

Energy for reproductive purposes accounted for $33 \%$ of available energy in females, $22 \%$ into eggs and $11 \%$ as sum total of all cellular respiration for reproductive purposes $\left(R_{\mathrm{r}}\right.$ in Table 7$)$. The total reproductive cost for large male $C$. tigris is the maintenance cost associated with the reproductive state and reproductionrelated behaviors. These costs accounted for an estimated $30 \%$ of energy flow in males (Table 7).

The incidence of reproduction-related behaviors is less in small males than in larger males so these smaller males are somewhat similar to females in that they are collecting extra energy for production of new tissue ( 24 $\mathrm{J} \cdot \mathrm{g}^{-0.80} \cdot \mathrm{d}^{-1}$; Table 5). If we consider production efficiency to be the energy allocation (in joules per day) to new tissue divided by the energy use (in joules per day) for increased maintenance plus tissue energy (equals $P_{\mathrm{r}} / P_{\mathrm{r}}+R_{\mathrm{r}}$ for females in Table 7 ), then the production efficiency of females $(0.65)$ was greater than that of small males $\left[\left(24 \mathrm{~J} \cdot \mathrm{g}^{-0.80} \cdot \mathrm{d}^{-1}\right) /\left(24 \mathrm{~J} \cdot \mathrm{g}^{-0.80} \cdot \mathrm{d}^{-1}+\right.\right.$ $\left.162 \mathrm{~J} \cdot \mathrm{g}^{-0.80} \cdot \mathrm{d}^{-1}\right)=0.13 ; P_{\mathrm{g}} /\left(P_{\mathrm{g}}+R_{\mathrm{r}}\right)$ in Table 7]. In other words, for a similar amount of production energy, the extra energy expended for maintenance was higher in males. Perhaps this is, in part, because young growing males are putting some time and energy into courtship in addition to production (some relatively small males do mate successfully: Anderson 1986). Production efficiencies defined similarly for Uta stansburiana ranged from 8 to $48 \%$, depending upon sex, size, and growth rate (Nagy 1983).

Comparison of reproductive effort ( $R E$ ) among species. - We performed two analyses in order to determine whether there was any relationship between RE and predation mode. First, we compared the RE of adult female $C$. tigris and $U$. stansburiana over the time to produce two clutches, that is, a reproductive season (Table 7). Second, we compared $\mathrm{RE}_{\mathrm{p}}$ (defined below) among several species.

To compare RE of $C$. tigris and $U$. stansburiana we calculate RE in two ways: reproductive effort excluding reproductive maintenance metabolism $\left(\mathrm{RE}_{\mathrm{p}}=P_{\mathrm{r}} / M\right)$ and total reproductive effort $\left(\mathrm{RE}_{\mathrm{t}}=P_{\mathrm{r}}+R_{\mathrm{r}} / M\right)$. The metabolic (total cellular respiratory) costs of reproduction, $R_{\mathrm{r}}$, included in the numerator of the $\mathrm{RE}_{\mathrm{t}}$ term dilute the importance of the production value, $R_{\mathrm{r}}$. A comparison of total apparent effort to reproduce, $\mathrm{RE}_{\mathrm{t}}$, with a measure of reproductive output per energy available, $\mathrm{RE}_{\mathrm{p}}$, may be illuminating.

Females of $C$. tigris and $U$. stansburiana put similar proportions of their total energy budget into the clutch, $\mathrm{RE}_{\mathrm{p}}=0.22$. The total reproductive effort, $\mathrm{RE}_{\mathrm{t}}$, of female Cnemidophorus (0.33) was one-half the $\mathrm{RE}_{\mathrm{t}}$ of female Uta (0.62). The difference in $\mathrm{RE}_{\mathrm{t}}$ is a consequence of (1) low metabolic cost for reproduction $\left(R_{\mathrm{r}}\right.$ in the numerator) in $C$. tigris, but a high $R_{\mathrm{r}}$ for $U$. stansburiana, and (2) relatively high metabolic costs for nonreproductive purposes (i.e., high $R_{\mathrm{n}}$ in the denominator), such as foraging, in $C$. tigris. In contrast, with both $R$ terms in the denominator, and only $P_{\mathrm{r}}$ in the numerator, $\mathrm{RE}_{\mathrm{p}}$ is similar in these two species because (1) maintenance metabolism accounts for $80 \%$ of all energy usage in both species, and (2) production is in the form of reproduction only, and accounts for $20 \%$ of all energy usage in both species. Analysis of the components of $R_{\mathrm{r}}$ in Uta and determination of the cause for such high $R_{\mathrm{r}}$ relative to $R_{\mathrm{n}}$ in Uta would be useful. We suspect the cause of high $R_{\mathrm{r}}$ in Uta will be greater length of activity period and more days active (Karasov and Anderson 1984).

A measure of the efficiency of reproduction in females is the energy deposited into eggs as a proportion of total energy usage for reproduction $\left(P_{\mathrm{r}} /\left[P_{\mathrm{r}}+R_{\mathrm{r}}\right]\right)$. Efficiency of reproduction was greater in Cnemidophorus, perhaps because the wide forager is more efficient at food acquisition than an ambusher (Anderson and Karasov 1981).

The metabolic costs of reproduction in lizards have been determined only for $U$. stansburiana and C. tigris. 
TABLE 8. Energy budgets of wide-foraging Cnemidophorus and ambush iguanids. $P_{\mathrm{r}^{\prime}}=$ apparent energy allocated to eggs (=clutch energy/time for clutch).

\begin{tabular}{|c|c|c|c|c|c|}
\hline \multirow[b]{2}{*}{ Species } & \multirow{2}{*}{$\begin{array}{l}\text { Body } \\
\text { mass } \\
(\mathrm{g})\end{array}$} & \multicolumn{2}{|c|}{$\begin{array}{l}\text { Energy flow } \\
\left(\mathrm{J} \cdot \mathrm{g}^{-0.80} \cdot \mathrm{d}^{-1}\right)\end{array}$} & \multirow{2}{*}{$\begin{array}{c}P_{\mathrm{r}^{\prime}} / \\
(\mathrm{FMR} \\
\left.+P_{\mathrm{r}^{\prime}}\right)\end{array}$} & \multirow[b]{2}{*}{ Reference } \\
\hline & & FMR & $P_{\mathrm{r}^{\prime}}$ & & \\
\hline \multicolumn{6}{|l|}{ Wide foragers } \\
\hline Cnemidophorus uniparens & 7.3 & $385^{*}$ & 132 & 0.26 & Hulse 1981 \\
\hline C. tigris & 16 & 430 & 129 & 0.23 & This study \\
\hline \multicolumn{6}{|l|}{ Ambushers } \\
\hline Uta stansburiana & 3.5 & 180 & 51 & 0.22 & Nagy 1983 \\
\hline Urosaurus ornatus & 4.0 & $224^{*}$ & 78 & 0.26 & Congdon et al. $1982 a$ \\
\hline Sceloporus merriami & 4.0 & $224 *$ & 69 & 0.24 & Congdon et al. $1982 a$ \\
\hline$S$. graciosus & 5.0 & 221 & 73 & 0.25 & Congdon and Tinkle 1982, Congdon et al. $1982 a$ \\
\hline S. virgatus & 7.6 & 209 & 40 & 0.18 & Merker and Nagy 1984 \\
\hline Callisaurus draconoides & 9.3 & 228 & 86 & 0.27 & W. H. Karasov and R. A. Anderson, personal observation \\
\hline
\end{tabular}

* FMR was estimated (see Discussion: III. Reproductive Effort in Cnemidophorus, with Comparisons: Comparison of Reproductive Effort among Species).

Therefore, to enlarge our comparison of reproductive effort among species we compared the quotient of energy per day into eggs (from Table 6) divided by the sum of egg energy and FMR (i.e., $P_{\mathrm{r}^{\prime}} /\left[P_{\mathrm{r}^{\prime}}+\right.$ FMR $]$ in Table 8) among several species of iguanids and Cnemidophorus indigenous to western North America. Some values of FMR for iguanids from Congdon et al. $(1982 a)$ were not based directly on labeled water measurements but were calculated from Nagy's (1982) allometric relationship for FMR. Similarly, we estimated FMR for Cnemidophorus uniparens based on an estimate of length of daily activity period $(6 \mathrm{~h} / \mathrm{d}$ : Hulse 1981) and the allometric relationship for FMR that we presented for Cnemidophorus (see Activity Period Costs during Reproduction, above).

We see no consistent relationship between reproductive effort defined in this way and predation mode, though the data are few. The values for all species are quite similar. Based on this small sample, $R E_{p}$ is apparently not different in ambushers and wide foragers. One important caveat is that this analysis and the previous analyses involve comparisons of species with different body masses, and $\mathrm{RE}_{\mathrm{p}}$ might be related in some way to body mass, as are so many factors (Western 1979).

Whereas wide foragers tend to have higher rates of production (Fig. 6B, Table 8), they also have higher FMRs. Therefore, the quotient of production energy to production plus maintenance energy could be independent of rate of energy flow. If so, no relationship may exist between $R E_{p}$ and food-acquisition mode; but $\mathrm{RE}_{\mathrm{t}}$ may be lower in animals of higher activity levels (in both time and intensity) because the $R_{\mathrm{r}}$ term is relatively low in an animal with enormous $R_{\mathrm{n}}$.

Male RE, "health" threshold, and range of female $R E_{p}$.-Reproductive effort $\left(\mathrm{RE}_{\mathrm{t}}\right)$ for males of $C$. tigris and $U$. stansburiana were similar at 0.3 , and maintenance for putative nonreproductive functions was 0.7 of available usage (Table 7). $R E_{t}$ in males is sometimes called mating effort (ME), to differentiate it from $R_{t}$ in females (Thornhill and Alcock 1983). If reproduction is of paramount importance to males, then ME should be high. But, loss of mass was minimal in these males (if there was little stored fat available at the beginning of the reproduction season) through the reproductive season. Perhaps there is some "healthy body mass" threshold, below which a male will not cross. Perhaps this "health" threshold exists also in females. There may be some physiological mechanism limiting the maximum RE of females, especially when food availability is low. The mechanisms may be physiological thresholds for loss of calcium, nitrogen, lipids, or some other essential elements or compounds. When food is available, ad libitum, maximum RE must also be limited; but in this extreme, RE is limited by rates of assimilation, clutch formation, and the maximum possible clutch mass, rather than some health threshold.

An evolutionary explanation for the health threshold may involve the fact that a fundamental characteristic of reproductive episodes in lizards is iteroparity. In virtually all species, females are physiologically capable of producing more than one clutch. Follicular atresia occurs in most oviparous lizards, and this atresia may be more common when low food availability results in lower food intake and fewer eggs produced (Ballinger 1977). We think that analyses of $R E_{p}$ (and $R E_{t}$ ), and the possible physiological thresholds and physiological and morphological limitation on RE under very low and very high food availability, would yield a useful perspective on life history adaptations among different populations and species.

\section{$I V$. Comparison of alternative measures of reproduction}

Reproduction of Cnemidophorus has been analyzed by us and others using at least four measures: (1) RCM, which is a static (single point in time, instantaneous) measure of mass or energy of eggs relative to the female; dynamic (rate-process) measures such as (2) number 


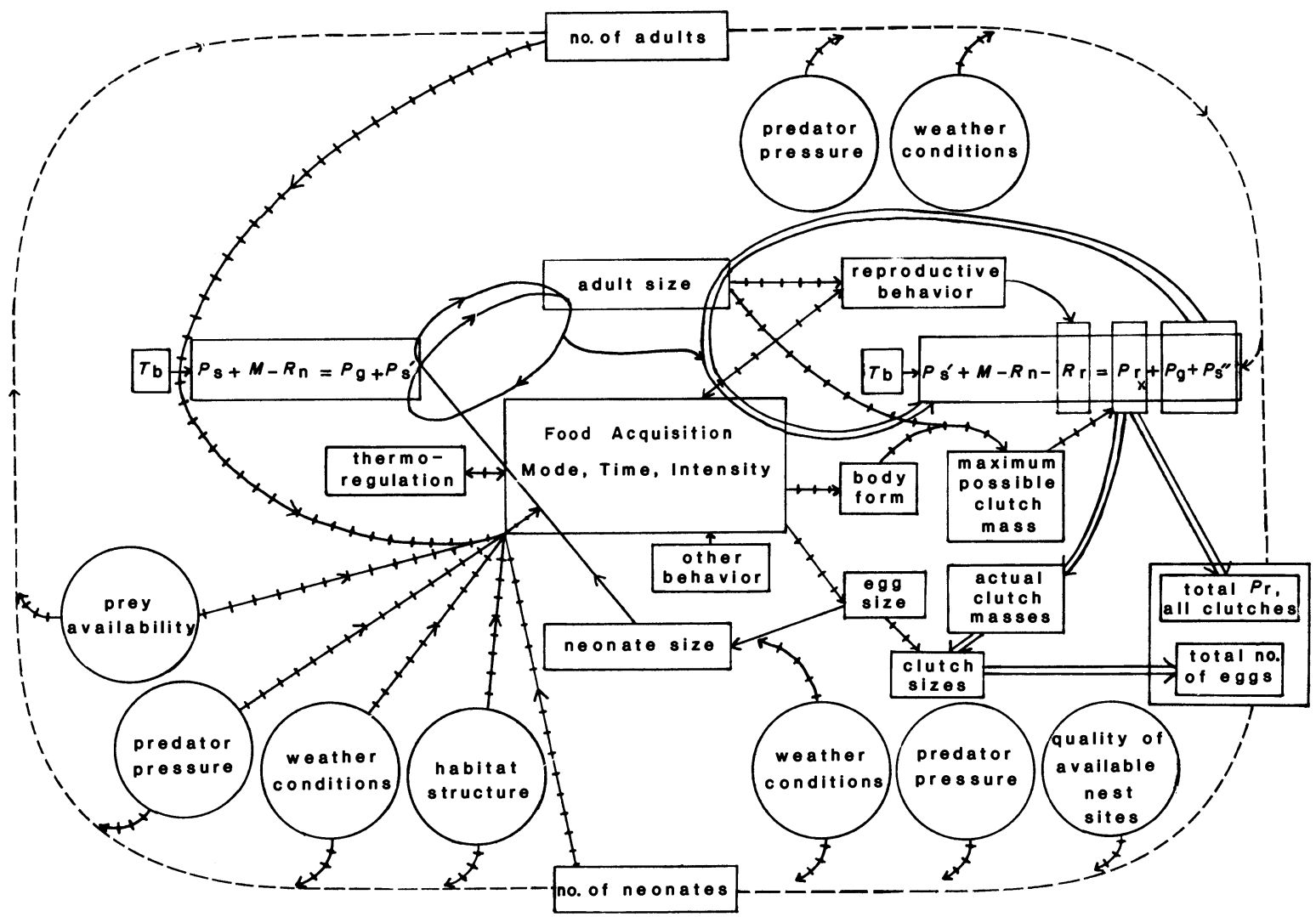

FIG. 8. Descriptive model of factors involved in production by lizards, with food acquisition as a central feature. This is a two-tiered cycle. The solid line is the inner cycle representing the individual, which acquires food, grows, becomes an adult, and reproduces. This inner cycle feeds into the outer cycle (dashed line) via "total number of eggs." The outer cycle represents the population, and follows cohorts from generation to generation. Attention should be focused on the inner cycle. The left half of the figure represents the transition from neonate to adult. The right half represents the reproductive season. The parallel lines represent repeated events within an individual during the reproductive season. Boxed parameters are features of the organism or population. Circled parameters are extrinsic factors influencing the organism or population. Crossed lines represent constraints or selection factors influencing the boxed, intrinsic features of the organism or population. The $M$ is metabolizable energy consumed, $R_{\mathrm{n}}$ is nonreproductive respiration (metabolism as sum total of cellular respiration not for reproduction) energy expended, $R_{\mathrm{r}}$ is reproductive respiration (reproductive metabolism) energy expended, $P_{\mathrm{g}}$ is growth production, $P_{\mathrm{s}}$ is storage production energy $\left(P_{\mathrm{s}}\right.$ is as subadult, $P_{\mathrm{s}^{\prime}}$ is for an adult prior to reproduction, $P_{\mathrm{s}^{\prime \prime}}$ is during reproduction), $P_{\mathrm{r}_{\mathrm{x}}}$ is reproductive production energy in a clutch mass, $P_{\mathrm{r}_{\mathrm{t}}}$ is reproductive production energy in the total of clutch masses, $T_{\mathrm{b}}$ represents the body temperatures experienced all $24 \mathrm{~h}$, every day.

of eggs per unit time or (3) energy flow; and (4) proportions, such as RE, which are ratios of energy flow. Fig. 8 illustrates the interrelated bases of these four measures.

These different measures are useful for investigating different ecological and evolutionary questions. We have discussed, for example, how differences in RCM between wide foragers and ambushers do not necessarily reflect differences in rates of reproduction. More likely, differences in RCM are a result of the coevolution of body shape, predator escape tactic, and foodacquisition mode in lizards (Vitt and Congdon 1978). The actual clutch mass varies with rate of production, within the constraints of this coevolution (Fig. 8; and Vitt and Congdon 1978).

It seems to us, in a pragmatic vein, that $\mathrm{RE}_{\mathrm{t}}$ may not have much utility for understanding major differences in life history phenomena. This conclusion follows from several considerations.

First, $R_{t}$ is a very data-intensive measure. To be properly determined it requires measurement of rate of production, rate of field metabolism, and also the rate of metabolism for reproductive activities (Congdon et al. 1982a). The latter is difficult to measure.

Second, the biologically meaningful time interval over which to measure RE may differ among species and populations, and within populations from year to year. The differences in the time intervals over which RE is measured (Congdon et al. 1982a, Nagy 1983, this paper) further make comparisons of RE problematical.

Third, the few studies to date that have succeeded in collecting most or all of these data have shown little 
correspondence between predicted and observed patterns for $\mathrm{RE}_{\mathrm{t}}$ in reptiles. But, it may take many years for enough studies to be done before comparisons will be statistically analyzable. Congdon et al. (1982a) reviewed estimates of $\mathrm{RE}_{\mathrm{t}}$ for iguanid lizards and turtles in relation to four life history predictions and, in most cases, observed patterns in apparent $\mathrm{RE}_{\mathrm{t}}$ were contrary to the hypotheses as explicated by Stearns (1977). $\mathrm{RE}_{\mathrm{t}}$ did not increase with age, was not lowest in long-lived species, and it was not lowest for species with unpredictable juvenile mortality; and a high $\mathrm{RE}_{\mathrm{t}}$ was not associated with such life history characteristics as rapid development, early maturity, and production of many small offspring.

A fourth difficulty with $\mathrm{RE}_{\mathrm{t}}$ was revealed in this study. The high cost of food acquisition in the wide forager (the species with a greater intensity of activity, but the greater foraging efficiency), results in an unusually low $\mathrm{RE}_{\mathrm{t}}$ in the wide forager. That the large difference in $R E_{t}$ between a wide forager and an ambusher is related to intrinsic differences in food acquisition efficiency makes us realize that comparisons of $R_{t}$ between species may be much more problematical than within a species.

Rather than focusing attention on $\mathrm{RE}_{t}$, we suggest that concentrating on rates of reproduction (or production) has utility for understanding life history phenomena, especially as these phenomena relate to foraging behavior and habitat productivity. For example, consideration of rates of production and reproduction offers an easier and useful way to look at within- and between-species differences in life history patterns (cf. Andrews 1979, 1984, Ballinger 1983). One can identify a direct link between patterns of behavior (e.g., foodacquisition mode), resource availability, and growth rates, and, consequently, such life history parameters as clutch frequencies and clutch sizes (Fig. 8).

In this study, for example, we showed that growth and reproductive rates were higher in years of high productivity (e.g., 1983). We have suggested that in habitats and seasons with low food availability, daily growth and reproductive rates are probably higher in wide-foraging lizards (especially when daily activity period lengths are similar between wide foragers and ambushers), and we have presented some preliminary supporting data.

It is also apparent that higher net rate of energy; intake in wide foragers gives these lizards life history traits that confound the general $r$ - and $K$-selection scenario when comparing them with ambushers. For example, Cnemidophorus have a younger age yet larger size at first reproduction, and they produce larger, fewer young per clutch than ambushers. Comparisons of mortality schedules and demographic patterns between lizards that differ in predation mode seem especially important to investigate.

Moreover, in the temperate zones, it seems that ther- moregulatory requirements may have a large effect on the length and nature of daily and seasonal activity, and consequently on rate of food intake and rate of production. Are the shortened activity periods of Cnemidophorus, with its high $T_{\mathrm{b}}$ when active, similar in length to those of iguanids with similar active $T_{\mathrm{b}}$ (not so in the case of syntopic $C$. draconoides: R. A. Anderson and W. Karasov 1981 and personal observation)? Or, is limited activity in Cnemidophorus a result of higher foraging efficiency, or greater predation pressure, or difficulties of thermoregulation in a wide forager (Huey and Slatkin 1976)? Some ambush iguanids with high active $T_{\mathrm{b}}$ may have lower production rates relative to those with lower active $T_{\mathrm{b}}$. Length of activity periods, rate of food intake, and metabolism associated with the daily regime of $T_{\mathrm{b}}$ seem important determinants of rates of production. In this regard, differences among species in the lengths of reproductive seasons would be especially important to total reproductive output.

In environments where lizard activity is year-round, the increased growth rates of wide foragers would perhaps result in earlier ages at reproductive maturity than similar-sized ambushers. Together with higher rates of reproduction, this could result in higher intrinsic rates of natural increase. In tropical habitats with equable climates, do species of wide foragers generally have higher population density and/or higher population biomass than ambushers? Alternatively, by virtue of high rates of net energy intake while foraging, wide foragers could reduce RE and shorten the length of their daily activity period or activity season. They would, then, be less exposed to predators and have an increased probability of future reproduction. Alternatively again, depending upon the habitats and predators present during the early evolution of a species, it may be selectively advantageous for wide foragers to stay out longer and grow to larger body size, thus (1) avoiding predation from small predators by virtue of larger body size, and (2) producing larger clutches and/ or larger eggs (i.e., greater potential reproductive success).

We think many aspects of these ideas and hypotheses can be investigated in the field. Progress in this area should be rapid as more careful determinations of growth rates and clutch intervals, specifically, and natural history data, generally, are made for reptiles in diverse habitats, of different food-acquisition modes, phylogenies, and life histories.

\section{ACKNOWLEDGMENTS}

We thank R. Andrews, J. Congdon, M. Feder, M. Greenfield, R. Huey, S. Jones, K. Nagy, and L. Vitt for manuscript review; S. James and R. Chacon for field assistance; and J. Howland, UCLA, for use of unpublished data. Financial assistance was received from the UCLA Graduate Division, the A. W. Schorger Fund, S. James, and DOE contract DE-AC0376-SF00013 to Ken Nagy. Manuscript preparation was aided 
by the Savannah River Ecology Laboratory and contract DEAC09-76SR-00819 between the United States Department of Energy and the University of Georgia.

\section{Literature Cited}

Anderson, R. A. 1986. Foraging behavior, energetics of reproduction, and sexual selection in a widely-foraging lizard, Cnemidophorus tigris. Dissertation. University of California, Los Angeles, California, USA.

1988. Analysis of foraging in a lizard, Cnemidophorus tigris: salient features and environmental effects. Los Angeles County Museum Contributions in Science.

Anderson, R. A., and W. H. Karasov. 1981. Contrasts in energy intake and expenditure in sit and wait and widely foraging lizards. Oecologia (Berlin) 49:67-72.

Andrews, R. M. 1976. Growth rate in island and mainland anoline lizards. Copeia 1976:477-482.

- 1979. Evolution of life histories and comparison of Anolis lizards from matched island and mainland habitats. Breviora 454.

1982. Patterns of growth in reptiles. Chapter 6. Pages 273-320 in C. Gans and H. F. Pough, editors. Biology of the Reptilia. Volume 7. Academic Press, New York, New York, USA.

1984. Energetics of sit-and-wait and widely searching lizard predators. Pages 137-146 in R. A. Seigel, L. E. Hunt, J. L. Knight, L. Malaret, and N. L. Zushlag, editors. Vertebrate ecology and systematics. University of Kansas, Special Publications of the Museum of Natural History 10.

Andrews, R. M., and F. H. Pough. 1985. Metabolism of squamate reptiles: allometric and ecological relationships. Physiological Zoology 58:214-231.

Appel, A. G., D. A. Reierson, and M. K. Rust. 1983. Comparative water relations and temperature sensitivity of cockroaches. Comparative Biochemistry and Physiology 74A:357-361.

Asplund, K. K. 1970. Metabolic scope and body temperatures of whiptail lizards (Cnemidophorus). Herpetologica 26:403-411.

Ballinger, R. E. 1976. Evolution of life history strategies: implications of recruitment in a lizard population following density manipulations. Southwestern Naturalist 21:203-208.

- 1977. Reproductive strategies: food availabilities as a source of proximal variation in a lizard. Ecology 58:628635 .

1983. Life-history variations. Chapter II. Pages 241260 in R. B. Huey, E. R. Pianka, and T. W. Schoener, editors. Lizard ecology: studies of a model organism. Harvard University Press, Cambridge, Massachusetts, USA.

Ballinger, R. E., and J. D. Congdon. 1981. Population ecology and life history strategy of a montane lizard (Sceloporus scalaris) in southeastern Arizona. Journal of Natural History 15:213-222.

Ballinger, R. E., D. L. Droge, and S. M. Jones. 1981. Reproduction in a Nebraska sandhills population of the northern prairie lizard Sceloporus undulatus garmani. American Midland Naturalist 106:157-164.

Ballinger, R. E., and G. D. Schrank. 1972. Reproductive potential of female lizards, Cnemidophorus gularis gularis. Herpetologica 28:217-222.

Ballinger, R. E., E. D. Tyler, and D. W. Tinkle. 1972. Reproductive ecology of a west Texas population of the greater earless lizard, Cophosaurus texanus. American Midland Naturalist 88:419-428.

Bartholomew, G. O. 1977. Energy metabolism. Chapter 3. Pages 57-110 in M. S. Gordon, editor. Animal physiology. Macmillan, New York, New York, USA.

Bennett, A. F., and W. R. Dawson. 1976. Metabolism. Pages
127-223 in C. Gans and W. R. Dawson, editors. Biology of the Reptilia. Volume 5. Academic Press, New York, New York, USA.

Bennett, A. F., and K. A. Nagy. 1977. Energy expenditure in free-ranging lizards. Ecology 58:697-700.

Blair, W. F. 1960. The rusty lizard: a population study. University of Texas Press, Austin, Texas, USA.

Bostic, D. L. 1966. A preliminary report of reproduction in the teiid lizard, Cnemidophorus hyperythrus beldingi. Herpetologica 22:81-90.

Brattstrom, B. H. 1965. Body temperatures of reptiles. American Midland Naturalist 73:376-422.

Burkholder, G. L., and W. W. Tanner. 1974. Life history and ecology of the Great Basin sagebrush swift Sceloporus graciosus graciosus Baird and Girard, 1852. Brigham Young University Science Bulletin Biological Series 19, Number 5.

Burkholder, G. L., and J. M. Walker. 1973. Habitat and reproduction of the desert whiptail lizard, Cnemidophorus tigris Baird and Girard in southwestern Idaho at the northern part of its range. Herpetologica 29:76-83.

Christiansen, J. L. 1971. Reproduction of Cnemidophorus inornatus and Cnemidophorus neomexicanus (Sauria, Teiidae) in northern New Mexico. American Museum Novitates Number 2442:1-48.

Clark, D. R. 1976. Ecological observations of a Texas population of six-lined racerunners, Cnemidophorus sexlineatus (Reptilia, Lacertilia, Teiidae). Journal of Herpetology 10:133-138

Cole, L. C. 1954. The population consequences of life history phenomena. Quarterly Review of Biology 29:103-137.

Collins, M. S. 1969. Water relations in termites. Chapter 14. Pages 433-457 in K. Krishna and F. M. Weesher, editors. Volume 1. Biology of termites. Academic Press, New York, New York, USA

Congdon, J. D., A. E. Dunham, and D. W. Tinkle. $1982 a$ Energy budgets and life histories of reptiles. Chapter 5. Pages 233-271 in C. Gans and H. F. Pough, editors. Biology of the Reptilia. Volume 13. Academic Press, New York, New York, USA.

Congdon, J. D., and D. W. Tinkle. 1982. Energy expenditure in free-ranging sagebrush lizards (Sceloporus graciosus). Canadian Journal of Zoology 60:1412-1416.

Congdon, J. D., L. J. Vitt, and N. F. Hadley. 1978. Parental investment: comparative reproductive energetics in bisexual and unisexual lizards, genus Cnemidophorus. American Naturalist 112:509-521.

Congdon, J. D., L. J. Vitt, R. C. Van Loben Sels, and R. D. Ohmart. 1982b. The ecological significance of water flux rates in arboreal desert lizards of the genus Urosaurus. Physiological Zoology 53:317-322.

Cuellar, O. 1984. Reproduction in a parthenogenetic lizard: with a discussion of optimal clutch size and a critique of clutch weight/body weight ratio. American Midland Naturalist 111:242-258.

Davis, J. 1967. Growth and size of the western fence lizard (Sceloporus occidentalis). Copeia 1967:721-731.

Derickson, W. K. 1976a. Lipid storage and utilization in reptiles. American Zoologist 16:711-723.

- 1976b. Ecological and physiological aspects of reproductive strategies in two lizards. Ecology 57:445-458.

Dunham, A. E. 1978. Food availability as a proximate factor influencing growth rates in the iguanid lizard Sceloporus merriamii. Ecology 59:770-778.

-1981. Populations in a fluctuating environment: the comparative population ecology of iguanid lizards Sceloporus merriamii and Urosaurus ornatus. University of Michigan Museum of Zoology Miscellaneous Publication Number 158

. 1982. Demographic and life-history variation among 
populations of the iguanid lizard Urosaurus ornatus: implications for the study of life-history phenomena in lizards. Herpetologica 38:208-221.

Dunham, A. E., and D. B. Miles. 1985. Patterns of covariation in life history traits of squamate reptiles: the effects of size and phylogeny reconsidered. American Naturalist 126: 231-257.

Dunn, O. J., and V. A. Clark. 1974. Applied statistics: analysis of variance and regression. John Wiley and Sons, New York, New York, USA.

Eckhardt, R. C. 1979. The adaptive syndromes of two guilds of insectivorous birds in the Colorado Rocky Mountains. Ecological Monographs 49:129-149.

Edney, E. B. 1977. Water balance in land arthropods. Springer-Verlag, New York, New York, USA.

Estes, R. 1983. The fossil record and early distribution of lizards. Pages 365-398 in A. Rhodin and K. Miyata, editors. Advances in herpetology and evolutionary biology. Museum of Comparative Zoology, Cambridge, Massachusetts, USA.

Ferguson, G. W., C. H. Bohlen, and H. P. Wooley. 1980. Sceloporus undulatus: comparative life history and regulation of a Kansas population. Ecology 61:313-322.

Ferguson, G. W., and T. Brockman. 1980. Geographic differences of growth rate of Sceloporus lizards (Sauria: Iguanidae). Copeia 1980:259-264.

Ferguson, G. W., K. L. Brown, and V. G. DeMarco. 1982. Selective basis for the evolution of variable egg and hatchling size in some iguanid lizards. Herpetologica 38:178188 .

Fisher, D. C. 1985. Evolutionary morphology: beyond the analogous, the anecdotal, and the ad hoc. Paleobiology 11: 120-138.

Fisher, R. A. 1930. The genetical theory of natural selection. Clarendon, Oxford, England.

Fitch, H. S. 1958. Natural history of the six-lined racerunner (Cnemidophorus sexlineatus). University of Kansas Publications of the Museum of Natural History 11:11-62.

Gaffney, F. G., and L. C. Fitzpatrick. 1973. Energetics and lipid cycles in the lizard, Cnemidophorus tigris. Copeia 1978: 446-452.

Gennaro, A. L. 1974. Growth, size, and age at sexual maturity of the lesser earless lizard, Holbrookia maculata maculata in eastern New Mexico. Herpetologica 30:85-90.

Gerritsen, J., and J. R. Strickler. 1977. Encounter probabilities and community structure in zooplankton: a mathematical model. Journal of the Fisheries Research Board of Canada 34:73-82.

Goldberg, S. R. 1973. Ovarian cycle of the western fence lizard, Sceloporus occidentalis. Herpetologica 29:281-289.

. 1975. Reproduction in the sagebrush lizard, Sceloporus graciosus. American Midland Naturalist 93:177187.

1976. Reproduction in a mountain population of the coastal whiptail lizard, Cnemidophorus tigris multiscutatus. Copeia 1976:260-266.

. 1977. Reproduction in a mountain population of the side-blotched lizard, Uta stansburiana (Reptilia, Lacertilia, Iguanidae). Journal of Herpetology 11:31-35.

Hahn, W. E., and D. W. Tinkle. 1965. Fat body cycling and experimental evidence for its adaptive significance to ovarian follicle development in the lizard Uta stansburiana. Journal of Experimental Zoology 158:79-86.

Harwood, R. H. 1979. The effect of temperature on the digestive efficiency of three species of lizards, Cnemidophorus tigris, Gerrhonotus multicarinatus and Sceloporus occidentalis. Comparative Biochemical Physiology 63A:417433.

Hirschfield, M. F., and D. W. Tinkle. 1975. Natural selec- tion and the evolution of reproductive effort. Proceedings of the National Academy of Sciences 72:2227-2231.

Hoddenbach, G. A. 1966. Reproduction in western Texas Cnemidophorus sexlineatus (Sauria: Teiidae). Copeia 1966: 110-113.

Huey, R. B., and A. E. Bennett. 1986. A comparative approach to field and laboratory studies in evolutionary biology. Pages 82-98 in M. E. Feder and G. V. Lauder, editors. Predator-prey relationships. University of Chicago Press, Chicago, Illinois, USA.

Huey, R. B., and E. R. Pianka. 1981. Ecological consequences of foraging mode. Ecology 62:991-999.

Huey, R. B., and M. Slatkin. 1976. Costs and benefits of lizard thermoregulation. Quarterly Review of Biology 51: 363-382.

Hulse, A. C. 1981. Ecology and reproduction of the parthenogenetic lizard Cnemidophorus uniparens (Teiidae). Annals of the Carnegie Museum 50:353-369.

Judd, F. W. 1975. Activity and thermal biology of the keeled earless lizard, Holbrookia propinqua. Herpteologica 31:137150.

1976. Demography of a barrier island population of the keeled earless lizard, Holbrookia propinqua. Occasional Paper of the Museum of Texas Technical University 44: $1-45$.

Karasov, W. H., and R. A. Anderson. 1984. Interhabitat differences in energy acquisition and expenditure in a lizard. Ecology 65:235-247.

Lifson, N., and R. McClintock. 1966. Theory of use of the turnover rates of body water for measuring energy and material balance. Journal of Theoretical Biology 12:46-74.

Mayhew, W. W. 1963a. Biology of the granite spiny lizard, Sceloporus orcutti. American Midland Naturalist 69:310 327.

. 1963b. Reproduction in the granite spiny lizard, Sceloporus orcutti. Copeia 1963:144-152.

1966a. Reproduction in the arenicolous lizard Uma notata. Ecology 47:9-18.

. $1966 b$. Reproduction in the psammophilous lizard Uma scoparia. Copeia 1966:114-122.

Mayr, E. 1976. Evolution and diversity of life: selected essays. Harvard University Press, Cambridge, Massachusetts, USA.

McCoy, C. J., Jr. 1965. Life history and ecology of Cnemidophorus tigris septentrionalis. Dissertation. Colorado State University, Fort Collins, Colorado, USA.

Medica, P. A. 1967. Food habits, habitat preference, reproduction, and diurnal activity in four sympatric species of whiptail lizards (Cnemidophorus) in southcentral New Mexico. Bulletin of the Southern California Academy of Sciences 66:251-276.

Merker, G. P., and K. A. Nagy. 1984. Energy utilization by free-ranging Sceloporus virgatus lizards. Ecology 65:575581.

Michel, L. 1976. Reproduction in a southwest New Mexican population of Urosaurus ornatus. Southwestern Naturalist 21:281-299.

Morton, E. S. 1973. On the evolutionary advantages and disadvantages of fruit eating in tropical birds. American Naturalist 107:8-22.

Nagy, K. A. $1980 . \mathrm{CO}_{2}$ production in animals: analysis of potential errors in the doubly labeled water method. American Journal of Physiology 238:R466-R473.

. 1982. Energy requirements of free-living iguanid lizards. Chapter 3. Pages 49-59 in G. M. Burghardt and A. S. Rand, editors. Iguanas of the world. Noyes, Park Ridge, New Jersey, USA.

- 1983. Ecological energetics. Pages 24-54 in R. B. Huey, T. Schoener, and E. R. Pianka, editors. Lizard ecol- 
ogy. Harvard University Press, Cambridge, Massachusetts, USA.

Nagy, K. A., and D. P. Costa. 1980. Water flux in animals: analysis of potential errors in the tritiated water method. American Journal of Physiology 238:R454-R465.

Nagy, K. A., R. B. Huey, and A. F. Bennett. 1984. Field energetics and foraging mode of Kalahari lacertid lizards. Ecology 65:588-596.

Nagy, K. A., and V. H. Shoemaker. 1975. Energy and nitrogen budgets of the free-living desert lizard Sauromalus obesus. Physiological Zoology 48:252-262.

Newlin, M. E. 1976. Reproduction in the bunch grass lizard, Sceloporus scalaris. Herpetologica 32:171-184.

Nussbaum, R. A. 1981. Seasonal shifts in clutch size and egg size in the side-blotched lizard, Uta stansburiana, Baird and Girard. Oecologia (Berlin) 49:8-13.

Parker, W. S. 1973. Natural history notes on the iguanid lizard Urosaurus ornatus. Journal of Herpetology 7:21-26.

Parker, W. S., and E. R. Pianka. 1973. Notes on the ecology of the iguanid lizard, Sceloporus magister. Herpetologica 29:143-152.

Parry, G. D. 1983. The influence of the cost of growth on ectotherm metabolism. Journal of Theoretical Biology 101: 453-477.

Pianka, E. R. 1966. Convexity, desert lizards, and spatial heterogeneity. Ecology 47:1055-1059.

Pianka, E. R., and W. S. Parker. 1972. Ecology of the iguanid lizard Callisaurus draconoides. Copeia 1972:493-508.

Pianka, E. R., and W. S. Parker. 1975. Ecology of horned lizards: a review with special reference to Phrynosoma platyrhinos. Copeia 1975:141-162.

Rand, A. S. 1982. Clutch and egg size in Brazilian iguanid lizards. Herpetology 38:171-178.

Regal, P. J. 1978. Behavioral differences between reptiles and mammals: an analysis of activity and mental capacities. Pages 183-202 in N. Greenberg and P. D. MacLean, editors. Behavior and neurology of lizards. National Institute of Mental Health, Rockville, Maryland, USA.

Ricklefs, R. E. 1974. Energetics of reproduction in birds. In R. A. Paynter, editor. Avian energetics. Publication of the Nuttall Ornithological Club 15:151-292.

Rogers, L. E., R. L. Buschbom, and C. R. Watson. 1977. Length-weight relationships of shrub-steppe invertebrates. Annals of the Entomological Society of America 70:51-53.

Root, R. B., and S. J. Chaplin. 1976. The lifestyles of tropical milkweed bugs, Oncopeltus (Hemiptera: Lygaeidae), utilizing the same hosts. Ecology 57:132-140.

Sage, R. D. 1982. Wet- and dry-weight estimates for insects and spiders based on length. American Midland Naturalist 108:407-410.

Schall, J. J. 1978. Reproductive strategies in sympatric whiptail lizards (Cnemidophorus): two parthenogenetic and three bisexual species. Copeia 1978:108-116.

Schmidt-Nielsen, K. 1975. Animal physiology. Cambridge University Press, New York, New York, USA.

Schoener, T. W. 1971. Theory of feeding strategies. Annual Review of Ecology and Systematics 2:369-404.

Shine, R. 1980. Costs of reproduction in reptiles. Oecologia (Berlin) 46:92-100.

Smith, C. C., and S. D. Fretwell. 1974. The optimal balance between size and number of offspring. American Naturalist 108: 499-506.

Smith, D. C. 1977. Interspecific competition and demography of two lizards. Dissertation. University of Michigan, Ann Arbor, Michigan, USA.

- 1981. Competitive interactions of the striped plateau lizard (Sceloporus virgatus) and the tree lizard (Urosaurus ornatus). Ecology 62:679-687.

Smith, D. D. 1974. Comparison of certain aspects of life history of two species of whiptail lizards (Cnemidophorus): one unisexual and one bisexual. Thesis. University of Missouri, Kansas City, Missouri, USA.

Stamps, J. A., and S. Tanaka. 1981. The influence of food and water on growth rates in a tropical lizard (Anolis aeneus). Ecology 62:33-40.

Stearns, S. C. 1977. The evolution of life history traits. Annual Review of Ecology and Systematics 8:145-172.

Stevens, T. P. 1983. Reproduction in an upper elevation population of Cnemidophorus inornatus (Reptilia, Teiidae). Southwestern Naturalist 28:9-20.

Tanner, W. W., and J. M. Hopkin. 1972. Ecology of Sceloporus occidentalis longipes Baird and Uta stansburiana stansburiana Baird and Girard on Ranier Mesa, Nevada Test Site, Nye County, Nevada. Brigham Young University Science Bulletin Biological Series 5:1-39.

Tanner, W. W., and J. E. Krogh. 1973a. Ecology of Phrynosoma platyrhinos, at the Nevada Test Site, Nye County, Nevada. Herpetologica 29:327-342.

Tanner, W. W., and J. E. Krogh. 1973b. Ecology of Sceloporus magister at the Nevada Test Site, Nye County, Nevada. Great Basin Naturalist 33:133-151.

Tanner, W. W., and J. E. Krogh. 1975. Ecology of the zebratailed lizard Callisaurus draconoides at the Nevada Test Site. Herpetologica 31:302-316.

Thornhill, R., and J. Alcock. 1983. The evolution of insect mating systems. Harvard University Press, Cambridge, Massachusetts, USA.

Tinkle, D. W. 1961. Population structure and reproduction in the lizard Uta stansburiana stejnegeri. American Midland Naturalist 66:206-234.

-1967. The life and demography of the side-blotched lizard, Uta stansburiana. University of Michigan Museum of Zoology Miscellaneous Publication Number 132.

- 1972. The dynamics of a Utah population of Sceloporus undulatus. Herpetologica 28:351-359.

. 1973. A population analysis of the sagebrush lizard, Sceloporus graciosus in southern Utah. Copeia 1973:284296.

296. 1976. Comparative data on the population ecology of the desert spiny lizard Sceloporus magister. Herpetologica 32:1-6.

Tinkle, D. W., and R. E. Ballinger. 1972. Sceloporus undulatus: a study of the intraspecific comparative demography of a lizard. Ecology 53:570-584.

Tinkle, D. W., and A. E. Dunham. 1983. Demography of the tree lizard Urosaurus ornatus, in central Arizona. Copeia 1983:585-598.

Turner, F. B., G. A. Hoddenbach, P. A. Medica, and J. R. Lannom. 1970. The demography of the lizard, Uta stansburiana Baird and Girard in southern Nevada. Journal of Animal Ecology 39:509-519.

Turner, F. B., P. A. Medica, and B. W. Kowalewsky. 1976. Energy utilization by a desert lizard (Uta stansburiana). B. E. Norton, editor. US/IBP Desert Biome Monograph Number 1. Utah State University Press, Logan, Utah, USA.

Van Loben Sels, R. C., and L. J. Vitt. 1984. Desert lizard reproduction: seasonal and annual variation in Urosaurus ornatus (Iguanidae). Canadian Journal of Zoology 62:17791787.

Vinegar, M. B. 1975a. Life history phenomena in two populations of the lizard Sceloporus undulatus in southwestern New Mexico. American Midland Naturalist 93:388-402. $1975 \mathrm{~b}$. Demography of the striped plateau lizard, Sceloporus virgatus. Ecology 56:172-182.

Vitt, L. J. 1977. Observations on clutch and egg size and evidence for multiple clutches in some lizards of southwestern United States. Herpetologica 33:333-338.

1978. Caloric content of lizard and snake (Reptilia) eggs and bodies and the conversion of weight to caloric data. Journal of Herpetology 12:65-72. 
Vitt, L. J., and J. D. Congdon. 1978. Body shape, reproductive effort and relative clutch mass in lizards: resolution of a paradox. American Naturalist 112:595-608.

Vitt, L. J., and R. D. Ohmart. 1975. Ecology, reproduction, and reproductive effort of the iguanid lizard Urosaurus graciosus on the lower Colorado River. Herpetologica 31:5665.

Vitt, L. J., and R. D. Ohmart. 1977. Ecology and reproduction of lower Colorado River lizards. II. Cnemidophorus tigris (Teiidae) with comparisons. Herpetologica 33:223234.

Vitt, L. J., and H. J. Price. 1982. Ecological and evolutionary determinants of relative clutch mass in lizards. Herpetologica 38:237-255.

Vleck, D. 1978. The energy cost of activity and growth Dissertation. University of California, Los Angeles, California, USA.

Weintraub, J. D. 1969. Size relationships of the granite spiny lizard, Sceloporus orcutti. Herpetologica 25:25-29.

Western, D. 1979. Size, life history and ecology of mammals. African Journal of Ecology 17:185-204.

Williams, G. C. 1966. Adaptation and natural selection Princeton University Press, Princeton, New Jersey, USA. 


\section{APPENDIX I.}

TABLE A1. Egg mass and egg energy of Cnemidophorus and iguanids.*

\begin{tabular}{|c|c|c|c|c|}
\hline & $\begin{array}{l}\text { Body } \\
\text { mass } \\
\text { (clutch- } \\
\text { free) } \\
\text { (g) }\end{array}$ & $\begin{array}{c}\text { Wet egg } \\
\text { mass } \\
(\mathrm{g} / \mathrm{egg})\end{array}$ & $\begin{array}{c}\text { Egg } \\
\text { energy } \\
\text { (kJ/egg) }\end{array}$ & $\begin{array}{l}\text { Refer- } \\
\text { ence§ }\end{array}$ \\
\hline \multicolumn{5}{|l|}{ Cnemidophorus } \\
\hline $\begin{array}{l}\text { C. exanguis } \\
\text { C. gularis } \\
\text { C. gularis } \\
\text { C. hyperythrus } \\
\text { C. inornatus } \\
\text { C. inornatus } \\
\text { C. sexlineatus } \\
\text { C. sonorae } \\
\text { C. tesselatus } \\
\text { C. tigris } \\
\text { C. tigris } \\
\text { C. tigris } \\
\text { C. tigris } \\
\text { C. uniparens }\end{array}$ & $\begin{array}{c}10.8 \\
8.0 \\
15.0 \\
4.5 \\
4.1 \\
7.7 \\
5.8 \\
17.2 \\
16.5 \\
9.55 \\
10.23 \\
15.1 \\
16.34 \\
8.2\end{array}$ & $\begin{array}{l}0.549 \\
0.474 \\
0.44 \\
0.361 \ddagger \\
0.296 \\
0.371 \\
0.78 \\
0.641 \dagger \\
0.738 \\
0.618 \\
0.594 \\
0.789 \dagger \\
0.867 \\
0.480 \dagger\end{array}$ & $\begin{array}{c}7.79 \dagger \\
6.73 \dagger \\
6.24 \dagger \\
5.12 \dagger \\
4.20 \dagger \\
5.26 \dagger \\
11.07 \dagger \\
9.09 \\
10.05 \dagger \\
9.81 \\
8.43 \dagger \\
11.19 \\
13.05 \\
6.81\end{array}$ & $\begin{array}{l}6 \\
6 \\
1 \\
3 \\
5 \\
4 \\
5 \\
4 \\
6 \\
8,9 \\
6 \\
4 \\
8,9 \\
4\end{array}$ \\
\hline \multicolumn{5}{|l|}{ Iguanids } \\
\hline $\begin{array}{l}\text { Callisaurus } \\
\text { draconoides } \\
\text { Cophosaurus }\end{array}$ & 9.38 & 0.530 & 6.68 & 8,9 \\
\hline $\begin{array}{c}\text { texanus } \\
\text { Holbrookia }\end{array}$ & 6.64 & 0.361 & 4.95 & 8,9 \\
\hline $\begin{array}{c}\text { maculata } \\
\text { Phrynosoma }\end{array}$ & 5.41 & 0.272 & 2.72 & 8,9 \\
\hline $\begin{array}{l}\text { cornutum } \\
P . \text { modestum } \\
P . \text { platyrhinos }\end{array}$ & $\begin{array}{r}43.06 \\
9.49 \\
18.06\end{array}$ & $\begin{array}{l}0.704 \\
0.352 \\
0.703\end{array}$ & $\begin{array}{l}6.00 \\
3.99 \\
8.04\end{array}$ & $\begin{array}{l}8,9 \\
8,9 \\
8,9\end{array}$ \\
\hline Urosaurus & & & & \\
\hline graciosus & 2.81 & 0.194 & 2.59 & 8,9 \\
\hline U. graciosus & 3.19 & 0.169 & 2.43 & 8,9 \\
\hline U. ornatus & 3.08 & 0.150 & 1.83 & 8,9 \\
\hline $\begin{array}{l}U . \text { ornatus } \\
\text { Uta stans- }\end{array}$ & 3.54 & 0.170 & 2.42 & 8,9 \\
\hline $\begin{array}{c}\text { buriana } \\
\text { Sceloporus }\end{array}$ & 2.78 & 0.199 & 2.68 & 8,9 \\
\hline clarki & 28.68 & 0.651 & 7.15 & 8,9 \\
\hline S. magister & 31.22 & 0.711 & 7.75 & 8,9 \\
\hline S. occidentalis & 6.95 & 0.293 & 3.93 & 8,9 \\
\hline S. occidentalis & 21.0 & 0.538 & $5.53 \dagger$ & 7 \\
\hline S. olivaceous & 35 & 0.532 & $5.49 \dagger$ & 2 \\
\hline S. scalaris & 3.59 & 0.180 & 2.16 & 8,9 \\
\hline S. undulatus & 6.24 & 0.240 & 3.53 & 8,9 \\
\hline S. undulatus & 9.21 & 0.333 & 4.22 & 8,9 \\
\hline S. virgatus & 5.96 & 0.284 & 3.03 & 8,9 \\
\hline
\end{tabular}

* If both egg mass and egg energy were not reported in the reference, one was calculated from the other based on the following conversion factors. For Cnemidophorus, wet eggs average $55.7 \%$ dry matter (Congdon et al. 1978, Vitt 1978) and $25.5 \mathrm{~J} / \mathrm{mg}$ dry mass (corrections for ash from Vitt 1978 , are recorrected). For iguanid species, we used Vitt's (1978) equation for interconversion between egg energy and egg wet mass.

$\dagger$ Indicates values that were calculated.

$\ddagger$ Based on the egg dimensions that were reported in the reference, egg wet mass was estimated as follows. First, egg volume was calculated based on the equation of an ellipsoid: volume $=4 \pi a b c / 3$; where $a=$ one-half egg length, $b=c=$ one-half egg width. Subsequently, egg mass was calculated using a linear relationship between egg mass and egg volume that was derived from Table 2 of Vitt 1977. The equation was: egg mass (in $\mathrm{mg})=35.52+0.775$ egg volume (in $\mu \mathrm{L}$ ); $r^{2}=0.93 ; n=22$.

$\S 1$, Ballinger and Schrank 1972; 2, Blair 1960; 3, Bostic 1966; 4, Congdon et al. 1978; 5, Fitch 1958; 6, Schall 1978; 7, Tanner and Hopkin 1972; 8, Vitt 1977; 9, Vitt 1978. 


\section{APPENDIX II}

TABLE A2. Data used to calculate "activity season age" at first reproduction, and also hatchling-to-adult growth normalized to activity season age.*

\begin{tabular}{|c|c|c|c|c|c|c|}
\hline & $\begin{array}{l}\text { Chrono- } \\
\text { logical age } \\
\text { at first } \\
\text { reproduction } \\
\text { (months) }\end{array}$ & $\begin{array}{l}\text { Total time } \\
\text { in } \\
\text { hiberna- } \\
\text { tion } \\
\text { (months) }\end{array}$ & $\begin{array}{l}\text { Hatch- } \\
\text { ling } \\
\text { body } \\
\text { mass } \\
(\mathrm{g})\end{array}$ & $\begin{array}{l}\text { Female body } \\
\text { mass at first } \\
\text { reproduc- } \\
\text { tion } \dagger \\
\text { (g) }\end{array}$ & $\begin{array}{l}\text { Spe- } \\
\text { cies } \\
\text { ID } \\
\text { num- } \\
\text { ber }\end{array}$ & Reference \\
\hline \multicolumn{7}{|l|}{ Wide foragers } \\
\hline \multirow{2}{*}{ Cnemidophorus exanguis } & 10 & 6 & $\approx 0.9$ & 7.0 & 22 & Medica 1967 \\
\hline & 10.5 & 6.5 & $\approx 0.9$ & 6.3 & 22 & Smith 1974 \\
\hline \multirow[t]{4}{*}{ C. gularis } & 11.5 & 6.5 & $\approx 0.8$ & 6.3 & 5 & Smith 1974 \\
\hline & 22 & 13 & $\approx 0.8$ & 10.5 & 5 & Smith 1974 \\
\hline & 10.5 & 6 & $\approx 0.8$ & 6.9 & 5 & Ballinger and Schrank 1972 \\
\hline & 21 & 12 & $\approx 0.8$ & 10.5 & 5 & Ballinger and Schrank 1972 \\
\hline $\begin{array}{l}\text { C. hyperythrus } \\
\text { C. inornatus }\end{array}$ & 9.5 & 3.5 & $\approx 0.7$ & 3.9 & 1 & Bostic 1966 \\
\hline \multirow{2}{*}{ C. inornatus } & 10 & 6 & 0.8 & 3.4 & 4 & Medica 1967 \\
\hline & 22 & 14.5 & $\approx 0.95$ & 6.5 & 4 & Stevens 1983 \\
\hline \multirow{3}{*}{ C. sexlineatus } & 10.75 & 6 & $\approx 0.9$ & 4.3 & 32 & Medica 1967 \\
\hline & 10 & 7 & 0.9 & 6.0 & 2 & Fitch 1958 \\
\hline & 10 & 6 & $\approx 0.9$ & 8.0 & 2 & Clark 1976 \\
\hline \multirow[t]{4}{*}{ C. tigris } & $\begin{array}{l}10 \\
9.5\end{array}$ & 6 & 0.9 & 4.9 & 2 & Hoddenbach 1966 \\
\hline & 22 & $3.5-4$ & $\approx 1.3$ & $\begin{array}{r}14.9 \\
89\end{array}$ & $\begin{array}{l}7 \\
7\end{array}$ & $\begin{array}{l}\text { This study } \\
\text { Burkholder and Walker } 1973\end{array}$ \\
\hline & $\begin{array}{l}22 \\
10.75\end{array}$ & $\begin{array}{r}15 \\
6\end{array}$ & $\begin{array}{l}\approx 1.3 \\
\approx 1.15\end{array}$ & $\begin{array}{l}8.9 \\
6.3\end{array}$ & $\begin{array}{l}7 \\
7\end{array}$ & $\begin{array}{l}\text { Burkholder and Walker } 1973 \\
\text { Medica } 1967\end{array}$ \\
\hline & 22 & 15 & $\approx 1.15$ & 9.0 & 7 & McCoy 1965 \\
\hline C. uniparens & 10.5 & 6 & 0.9 & 6.5 & 3 & Hulse 1981 \\
\hline \multicolumn{7}{|l|}{ Ambushers } \\
\hline \multirow{2}{*}{ Callisaurus draconoides } & 22 & 12 & 0.70 & 9.5 & 16 & Tanner and Krogh 1975 \\
\hline & 12 & 3 & 0.70 & 7.5 & 16 & Pianka and Parker 1972 \\
\hline \multirow[t]{2}{*}{ Cophosaurus texanus } & 11 & 4 & 0.48 & 4.6 & 33 & J. Howland, personal communcation \\
\hline & 11 & 4.5 & $\approx 0.22$ & 4.8 & 33 & Ballinger et al. 1972 \\
\hline Holbrookia maculata & 10 & 4 & $\approx 0.4$ & 4.0 & 25 & Gennaro 1974 \\
\hline \multirow{3}{*}{$\begin{array}{l}H . \text { propinqua } \\
\text { Phrynosoma platyrhinos }\end{array}$} & 10.5 & 4 & $\approx 0.65$ & 3.5 & 34 & Judd 1975, 1976 \\
\hline & 21 & 13 & 1.0 & 19.6 & 28 & Pianka and Parker 1975 \\
\hline & 22.5 & 10.5 & 1.0 & 24.6 & 28 & Tanner and Krogh $1973 a$ \\
\hline \multirow[t]{3}{*}{ Sceloporus graciosus } & 23 & 12 & 0.49 & 5.2 & 12 & Tinkle 1973; Congdon and Tinkle 1982 \\
\hline & 23 & 11.5 & 0.56 & 6.1 & 12 & Burkholder and Tanner 1974 \\
\hline & 21 & 8.75 & 0.70 & 5.8 & 12 & Goldberg 1975 \\
\hline \multirow[t]{3}{*}{ S. magister } & 22.5 & 10.5 & $\approx 1.1$ & 17.5 & 21 & Tinkle 1976 \\
\hline & 22 & 10 or 16 & 1.25 & 20 & 21 & Tanner and Krogh $1973 b$ \\
\hline & 22.5 & 10.5 & 1.2 & 20 & 21 & Parker and Pianka 1973 \\
\hline \multirow{4}{*}{ S. occidentalis } & 11 & 6 & 0.4 & 3.5 & 11 & Dunham 1981 \\
\hline & 22 & 13 & 0.63 & 16 & 17 & Tanner and Hopkin 1972 \\
\hline & 11.5 & 3 & $\approx 0.59$ & 8.2 & 17 & Goldberg 1973 \\
\hline & 22 & 6 & 0.5 & 12.3 & 17 & Davis 1967 \\
\hline S. olivaceous & 22 & 6 & $\approx 0.59$ & 10.6 & 17 & Goldberg 1973 \\
\hline \multirow{2}{*}{ S. orcutti } & 11 & 3.5 & 0.46 & 17.5 & 20 & Blair 1960 \\
\hline & $\begin{array}{l}22 \\
34\end{array}$ & 6 & $\approx 1.0$ & 22 & 35 & Mayhew $1963 a, b$ \\
\hline S. scalaris & $\begin{array}{r}34 \\
8\end{array}$ & $\begin{array}{l}9 \\
2\end{array}$ & $\approx 1.0$ & 28 & 35 & Weintraub 1969 \\
\hline & $\begin{array}{l}8 \\
8\end{array}$ & $\begin{array}{l}2 \\
2\end{array}$ & $\begin{array}{l}\approx 0.4 \\
\approx 0.4\end{array}$ & 3.9 & 14 & Ballinger and Congdon 1981 \\
\hline S. undulatus & 9.5 & 3.5 & $\begin{array}{l}\approx 0.4 \\
\approx 0.44\end{array}$ & $\begin{array}{l}3.1 \\
6.6\end{array}$ & 14 & $\begin{array}{l}\text { Newlin } 1976 \\
\text { Tinkle and Ballinger } 1972\end{array}$ \\
\hline & 20 & 11 & $\begin{array}{l}\approx 0.44 \\
\approx 0.50\end{array}$ & $\begin{array}{r}6.6 \\
11.3\end{array}$ & $\begin{array}{l}30 \\
30\end{array}$ & \\
\hline & 10.5 & 5.5 & $\begin{array}{l}\approx 0.50 \\
\approx 0.5\end{array}$ & $\begin{array}{r}11.3 \\
5.5\end{array}$ & $\begin{array}{l}30 \\
30\end{array}$ & $\begin{array}{l}\text { Tinkle and Ballinger } 1972 \\
\text { Ballinger et al. } 1981\end{array}$ \\
\hline & 11 & 5.5 & 0.5 & $\begin{array}{l}5.5 \\
5.4\end{array}$ & 30 & $\begin{array}{l}\text { Ballinger et al. } 1981 \\
\text { Ferguson et al. } 1980\end{array}$ \\
\hline & $90 \%$ at 21 & 9 & 0.55 & 10.7 & 30 & $\begin{array}{l}\text { Ferguson et al. } 1980 \\
\text { Tinkle } 1972\end{array}$ \\
\hline & 12 & 4 & 0.5 & 5.8 & 30 & $\begin{array}{l}\text { Tinkle } 1972 \\
\text { Vinegar } 1975 a\end{array}$ \\
\hline & $50 \%$ at 12 & 5 & 0.5 & 4.8 & 30 & $\begin{array}{l}\text { Vinegar } 1975 a \\
\text { Vinegar } 1975 a\end{array}$ \\
\hline & $50 \%$ at 21 & 10 & & 6.5 & 30 & \\
\hline S. virgatus & $80 \%$ at 21 & 12 & 0.4 & 5.8 & 13 & Smith 1981 \\
\hline & $20 \%$ at 10 & 6 & & 5.4 & 13 & $\begin{array}{l}\text { Smith } 1981 \\
\text { Vinegar } 1975 b\end{array}$ \\
\hline Uma scoparia & 22 & 8 & & $70=\mathrm{SVL}$ & & $\begin{array}{l}\text { Vinegar } 1975 b \\
\text { Mayhew } 1966 b\end{array}$ \\
\hline Urosaurus graciosus & 12 & 3.5 & $\approx 0.3$ & 3.0 & 31 & $\begin{array}{l}\text { Mayhew } 1966 b \\
\text { Vitt and Ohmart } 1975\end{array}$ \\
\hline U. ornatus & 9.5 & 5 & $\approx 0.3$ & 2.8 & 9 & $\begin{array}{l}\text { Vitt and Ohmart } 1975 \\
\text { Smith } 1977\end{array}$ \\
\hline & 11 & 4.5 & $\approx 0.3$ & 2.9 & 9 & $\begin{array}{l}\text { Smith } 1977 \\
\text { Tinkle and Dunham } 1983\end{array}$ \\
\hline & 11 & 3.5 & $\approx 0.3$ & 2.6 & 9 & Van Loben Sels and Vitt 1984 \\
\hline & 10.5 & 4.5 & $\approx 0.3$ & 2.8 & 9 & Dunham 1981 \\
\hline & 11 & 3.5 & 0.4 & 2.8 & 9 & Ballinger 1976, 1977, Michel 1976 \\
\hline & 9.5 & 3 & $\approx 0.33$ & 2.6 & 9 & Parker 1973 \\
\hline
\end{tabular}


APPENDIX II. Continued.

\begin{tabular}{ccccccc}
\hline \hline & $\begin{array}{c}\text { Chrono- } \\
\text { logical age } \\
\text { at first } \\
\text { reproduction } \\
\text { (months) }\end{array}$ & $\begin{array}{c}\text { Total time } \\
\text { in } \\
\text { hiberna- } \\
\text { tion } \\
\text { (months) }\end{array}$ & $\begin{array}{c}\text { Hatch- } \\
\text { ling } \\
\text { body } \\
\text { mass } \\
(\mathrm{g})\end{array}$ & $\begin{array}{c}\text { Female body } \\
\text { mass at first } \\
\text { reproduc- } \\
\text { tion } \dagger \\
(\mathrm{g})\end{array}$ & $\begin{array}{c}\text { Spe- } \\
\text { cies } \\
\text { ID } \\
\text { num- } \\
\text { ber }\end{array}$ & Reference \\
\hline Uta stansburiana & 10 & 2 & 0.25 & 2.0 & 10 & Turner et al. 1970 \\
& 8 & 1 & $\approx 0.25$ & 3.5 & 10 & $\begin{array}{c}\text { Tinkle 1967 } \\
\text { Goldberg 1977 }\end{array}$ \\
\hline
\end{tabular}

* In many instances incomplete data sets were completed, or estimates by the original researchers had to be changed, based on other sources of information. Thus, subsequent comparisons of ambushers and wide forgers have the taint of subjectivity. But, in the absence of precise data on hourly, daily, and seasonal activity in different lizards within and between habitats, we hope these comparisons are acceptable.

† For the following species, body mass was estimated from relationships between body mass and snout-vent length (SVL): Cnemidophorus sexlineatus, $\ln ($ mass $)=2.826 \ln (\mathrm{SVL})-10.047$ (Fitch 1958); C. tigris, $\ln (\operatorname{mass})=3.11 \ln (\mathrm{SVL})-11.11$ (this study); Cophosaurus texanus, $\ln (\mathrm{mass})=3.081 \ln (\mathrm{SVL})-10.769$ (J. Howland, personal communication); Phrynosoma platyrhinos, $\ln ($ mass $)=2.921 \ln (\mathrm{SVL})-9.597$ (from tabular data in Pianka and Parker 1975); Sceloporus merriami, $\ln (\mathrm{mass})=$ $2.71 \ln (\mathrm{SVL})-9.405$ (Dunham 1981); S. occidentalis, (mass) $=4.44-0.31$ (SVL) + 0.0062 (SVL) (Davis 1967); Urosaurus ornatus, $\ln (\mathrm{mass})=1.642 \ln (\mathrm{SVL})-5.492$ (Dunham 1981). For Callisaurus draconoides, body masses were estimated based on masses of lizards with similar SVL at Desert Center, California (R. A. Anderson and W. H. Karasov, personal observation). 